EXORBITANT PRIVILEGE? QUANTITATIVE EASING AND THE BOND MARKET SUBSIDY OF PROSPECTIVE FAlde Acharyas

Matteo Crosignani Tim Eisert

WORKING PAPé Spigt 29777 
NBER WORKING PAPER SERIES

\title{
EXORBITANT PRIVILEGE? QUANTITATIVE EASING AND THE BOND MARKET SUBSIDY OF PROSPECTIVE FALLEN ANGELS
}

\author{
Viral V. Acharya \\ Ryan Banerjee \\ Matteo Crosignani \\ Tim Eisert \\ Renée Spigt \\ Working Paper 29777 \\ http://www.nber.org/papers/w29777
NATIONAL BUREAU OF ECONOMIC RESEARCH
1050 Massachusetts Avenue
Cambridge, MA 02138 \\ February 2022, Revised June 2022
}

We thank Ed Altman, Jennie Bai, Antonio Falato, Quirin Fleckenstein, Victoria Ivashina, Kose John, Jane (Jian) Li, Francis Longstaff, Camelia Minoiu, Andrea Presbitero, and Tyler Muiror their comments. We also thank seminar and conference participants at the NBER Summer Institute Capital Markets and the Economy, AFA Annual Meetings, Cornell, Oxford Said-ETH Zurich Macro-finance Conference, 10th MoFiR Workshop on Banking, KAIST, Deutsche Bundesbank/FRIC/CEPR ICredit Risk over the Business Cycle" conference, FSB Systemic Risks in Non-Bank Financial Intermediation conference, 2021 Federal Reserve Stress Testing Research conference, Bank of Spain, NYU Shanghai Joint-School Macro/Finance Seminar, NYU Stern, Cornell, Korea University Business School, KU Leuven, University of Melbourne, Norges Bank, Erasmus Rotterdam, University of South Carolina, New York Fed, University of Bonn, Humboldt University, ESADE Spring Workshop, and the BIS for valuable comments. We thank Erica Bucchieri and William Arnesen for excellent research assistance. The views expressed in this paper are those of the authors and do not necessarily represent those of the Federal Reserve Bank of New York, the Federal Reserve System, the BIS, or any of their staff. A previous version of this paper circulated with the title "Exorbitant Privilege? The Bond Market Subsidy of Prospective Fallen Angels." The views expressed herein are those of the authors and do not necessarily reflect the views of the National Bureau of Economic Research.

NBER working papers are circulated for discussion and comment purposes. They have not been peer-reviewed or been subject to the review by the NBER Board of Directors that accompanies official NBER publications.

(C) 2022 by Viral V. Acharya, Ryan Banerjee, Matteo Crosignani, Tim Eisert, and Renée Spigt. All rights reserved. Short sections of text, not to exceed two paragraphs, may be quoted without explicit permission provided that full credit, including $(\subset)$ notice, is given to the source. 
Exorbitant Privilege? Quantitative Easing and the Bond Market Subsidy of Prospective Fallen Angels

Viral V. Acharya, Ryan Banerjee, Matteo Crosignani, Tim Eisert, and Renée Spigt

NBER Working Paper No. 29777

February 2022, Revised June 2022

JEL No. E44,E52,E58,G01,G20

\section{ABSTRACT}

We document capital misallocation in the U.S. investment-grade (IG) corporate bond market, driven by quantitative easing (QE). Prospective fallen angels-risky firms just above the IG rating cutoff-enjoyed subsidized bond financing since 2009, especially when the scale of QE purchases peaked and from long-duration IG-focused investors that held more securities purchased in QE programs. The benefiting firms used this privilege to fund risky acquisitions and increase market share, exploiting the sluggish adjustment of credit ratings in downgrading after M\&A, which adversely affected competitors' employment and investment. Eventually, these firms suffered severe downgrades at the onset of the pandemic.

Viral V. Acharya

Stern School of Business

New York University

44 West 4th Street, Suite 9-65

New York, NY 10012

and CEPR

and also NBER

vacharya@stern.nyu.edu

Ryan Banerjee

Macroeconomic Analysis

Bank for International Settlements

Centralbahnplatz 2

CH-4002 Basel

Switzerland

ryan.banerjee@bis.org

Matteo Crosignani

New York Fed

mcrosign@gmail.com
Tim Eisert

Erasmus University Rotterdam

Burg. Oudlaan 50 / PO Box 1738

3000 DR Rotterdam

The Netherlands

eisert@ese.eur.nl

Renée Spigt

Erasmus University Rotterdam

Burgemeester Oudlaan 50

P.O. Box 1738

Rotterdam 3000 DR

The Netherlands

spigt@ese.eur.nl 


\section{Introduction}

Risky firms just above the investment-grade (IG) cutoff, i.e., risky BBB-rated firms, face the prospect of becoming "fallen angels" upon a downgrade and experiencing a steep increase in their cost of borrowing. Despite this risk, the BBB segment of the corporate bond market has been the fastest-growing IG rating category since the Global Financial Crisis (GFC). Between 2008 and 2020, the amounts outstanding of BBB-rated bonds have more than tripled in size to $\$ 3.5$ trillion, representing $55 \%$ of all investment-grade debt, up from $33 \%$ in 2008 . During the same period, Figure 1 shows that BBB bond spreads dropped from around 400 basis points to around 150 basis points (left panel); however, the profitability of BBB-rated firms did not keep up with their increased indebtedness (right panel). These dynamics are unique to the BBB rating category. Other IG bond spreads did not fall as much during the same period and other IG-rated issuers actually improved their debt-to-profitability ratio. Indeed, BBB-rated firms also exhibit higher book and market leverage over the 2009-2019 period, whereas for other IG firms leverage declined.

In many respects, the growth of risky IG bonds may be a desired outcome of monetary policy easing post the GFC. In particular, Quantitative Easing (QE) has aimed to push investors into riskier assets by lowering the yields on government and mortgage-backed bonds (Gagnon et al., 2011), and lowering in turn the yields on these other (long-term) riskier assets (Krishnamurthy and Vissing-Jorgensen, 2011). However, the growing concentration of
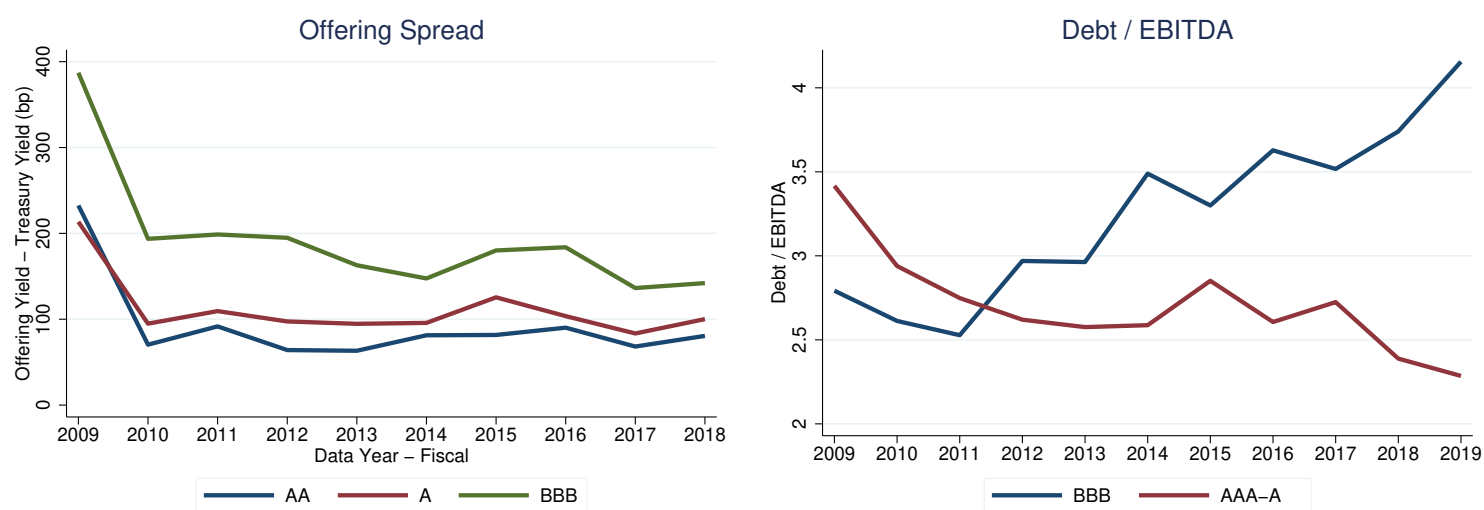

Figure 1: Increased fragility and lower bond financing costs for BBB-rated firms. This figure shows the increasing fragility and the declining bond financing costs for BBB-rated firms. The left panel shows the offering spread (primary market bond yields minus the Treasury yield with a similar maturity) for newly issued bonds. The right panel shows the asset-weighted debt over EBITDA for BBB and other IG-rated firms. Figure G.3 provides further non-parametric evidence that the bond financing cost of BBB firms dropped significantly, more than the financing costs of other IG issuers. 
issuance in the riskiest IG bucket also comes with a buildup of vulnerabilities in the corporate sector. In particular, the fragility of the BBB bonds and issuers materialized at the onset of the COVID-19 crisis. The volume of debt downgraded from BBB in a few weeks at the beginning of 2020 - in many cases by multiple notches - was more than two times larger than the volume of similar downgrades during the entire GFC. These observations were echoed in the remarks made on March 20, 2020 by the Secretary of the Treasury Yellen, who stated that "Non-financial corporations entered this crisis with enormous debt loads, and that is a vulnerability. They had borrowed excessively in my view through issuing corporate bonds and leveraged loans. Arguably, this was a borrowing binge that was incented by the long period we had of low interest rates. Investors were also engaged in a search for yield, so this debt was attractive to pension funds, insurance companies, and investors [...]". The materialization of this vulnerability likely led to the Federal Reserve stepping in to stabilize the U.S. corporate bond market in the wake of the COVID-19 shock. $^{1}$

In this paper, we provide a potential explanation for these phenomena by examining the causes and consequences of an exorbitant privilege in the form of a bond market subsidy for "prospective fallen angels", i.e., firms on the cusp of the investment-grade cutoff. We classify prospective fallen angels as BBB-rated firms that are vulnerable to downgrades, and show that BBB bond growth has largely been driven by such firms. Our analysis shows that prospective fallen angels have benefited from investors subsidizing their bond financing since 2009, especially when QE peaked during 2013-2016.

Importantly, we document that investors highly exposed to the Federal Reserve QE and typically investing in long-duration IG assets drive the demand for bonds issued by prospective fallen angels. ${ }^{2}$ This pattern is consistent with a delay in the balance-sheet normalization by the Federal Reserve following the "taper tantrum" of 2013, keeping rates low for longer and

\footnotetext{
${ }^{1}$ Remarks by Secretary Yellen were made at the "COVID-19 and the economy" webinar at Brookings Institution (link). See Gilchrist et al. (2020) for details on the impact of the Federal Reserve's intervention on fallen angels.

${ }^{2}$ In practice, investors such as insurance companies seek out a greater quantity of riskier IG assets to meet their promised liabilities as IG assets are close substitutes for securities such as Treasuries purchased (and whose yields as a result get compressed) by the Fed in QE programs.
} 
inducing in a set of financial intermediaries a search for risk due to net-worth considerations. Prospective fallen angels meet this demand of long-duration IG-focused QE-exposed investors by issuing bonds, largely to finance risky acquisitions. In conjunction, rating agencies in normal times appear to inflate ratings and delay downgrades for these firms that engage in M\&A transactions, reinforcing the demand for their bonds by QE-exposed investors. Finally, we document that this exorbitant privilege of prospective fallen angels appears to have had real effects, as these firms increase their market share via M\&As and exert negative externalities on more prudent firms similar to the congestion effect created by zombie firms (see, among others, Cabellero at al., 2008).$^{3}$

Our empirical analysis illustrating this mechanism combines various data sources at the issuer-level, bond-level, and investor-level. We use issuer-level data from Compustat and WRDS Capital IQ, and ratings data from Standard and Poor's, Moody's, and Fitch. Our bond-level data consists of primary market prices from Mergent and secondary market prices from TRACE. Finally, for a crucial part of our analysis that highlights the demand for risky bonds arising from IG-focused investors exposed to QE, we use investor holding-level data from eMAXX Bond Holders matched with security-level holdings in the Federal Reserve System Open Market Account (SOMA) portfolio.

We begin our empirical analysis by introducing a measure of downgrade-vulnerability based on the Altman Z"-score (Altman, 2020), a variable built with balance sheet and income statement information. Specifically, we classify a firm as "downgrade-vulnerable" if its Z"-score is lower than the historical median Z"-score of the next lowest rating category. We confirm the validity of our measure by documenting that downgrade-vulnerable firms (i)

\footnotetext{
${ }^{3}$ Anecdotal evidence supports our narrative. For example, consider the consumer product giant Newell Brands, which we classify as a prospective fallen angel since 2014. Newell Brands enjoyed bond spreads 30-50 basis points below the median bond spreads of BBB-rated firms and used this cheap financing, at least partly, to finance acquisitions from 2014 to 2017. For example, Newell Brands acquired Jarden in 2016, leading to an increase in leverage (gross debt/EBITDA) from 3 to 4.5. While the acquisition was accompanied by a promise to delever to 3-3.5 in 2-3 years, Newell Brands became more fragile post-M\&A, an evolution not reflected by its credit ratings. In 2015, S\&P rated the firm BBB- while our balance sheet implied rating was just B. S\&P maintained a BBB- rating until 2018 even if our balance sheet implied rating dropped to CCC+ by that time. Newell Brands became eventually a fallen angel, dropping below the IG cutoff, only in 2019.
} 
look worse along various observable firm characteristics, such as leverage, profitability, net worth, and interest coverage ratio; (ii) exhibit lower employment growth, investment, sales, and asset growth once they become vulnerable; and (iii) are more likely to be downgraded or put on negative watchlist/outlook than non-downgrade-vulnerable firms.

Using this measure, we define a "prospective fallen angel" as a BBB-rated firm that is vulnerable to being downgraded. ${ }^{4}$ We show that prospective fallen angels benefit from ratings inflation, defined as the difference between an issuer's credit rating as implied by its Z"-score and its observed credit rating. The ratings inflation for prospective fallen angels has been substantially increasing since 2009. Next, we document that there has been a reduction in bond spreads in the BBB segment, primarily driven by prospective fallen angels. The decline has been so dramatic that these firms have been able to obtain cheaper funding than their safer, i.e., non-downgrade-vulnerable counterparts, in the BBB rating class (Figure 2, left panel). Crucially, this pattern is only present for BBB-rated firms. We do not find analogous evidence in other rating categories. Moreover, such pattern in borrowing cost is not observed in corporate bond markets pre-2009. When replacing the bond spread with an equity market based measure of expected default, spreads in syndicated loan markets, or bond spreads before the GFC, we find that across all rating categories (including BBB), downgrade-vulnerable firms have higher - not lower - funding costs.

In other words, we identify for the BBB-rated firms a corporate bond market subsidy, which we refer to as the "exorbitant privilege" of prospective fallen angels. The total subsidy that accrues to the firm is the interest expense savings over the lifetime of its issued bonds and is shown in the right panel of Figure 2 for different rating categories. The subsidy consists of two components. For instance, for BBB rating, one component derives from the relative subsidy in bond financing for prospective fallen angels within the BBB rating bucket, shown by the grey bar. The second component, shown by the green bar, is the interest saving that accrues to prospective fallen angels from not being downgraded to a speculative-grade rating;

\footnotetext{
${ }^{4}$ In 2018, the corporate bond volume of prospective fallen angels amounted to $\$ 1.5$ trillion (\$0.5 trillion in 2009), compared to the $\$ 0.5$ trillion of BBB non-downgrade-vulnerable firms $(\$ 0.25$ trillion in 2009$)$.
} 

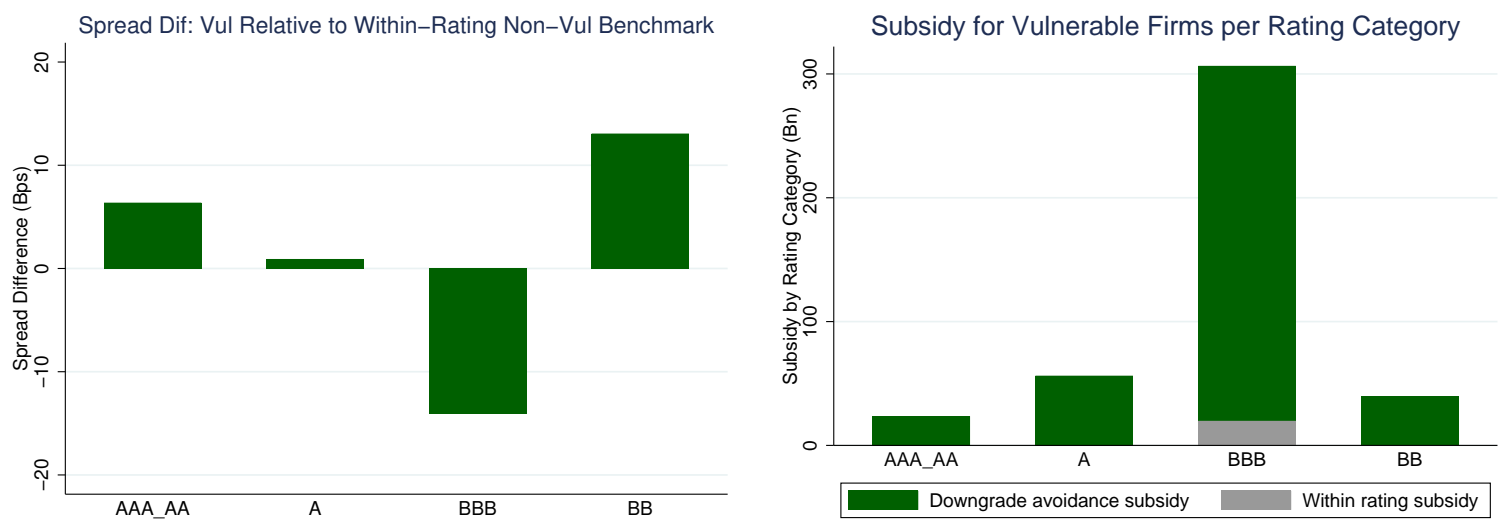

Figure 2: The privilege of prospective fallen angels. The left panel shows the difference in basis points between the mean offering spread of firms defined as being downgrade-vulnerable and the mean offering spread of non-downgrade-vulnerable firms in the same rating category. We classify a firm as downgrade-vulnerable if its estimated Z"-score is lower than the Altman Z"-score benchmark of the next lowest rating category. The right panel plots the total interest expenses that downgrade-vulnerable firms do not have to bear over the lifetime of their bonds, by not being downgraded to the next lowest rating category. The green bars are the difference between the mean offering spread of downgrade-vulnerable firms in a given rating category relative to the mean offering spread of non-downgrade-vulnerable firms in the next lowest rating category, multiplied by the average maturity and the total offering amount of the bonds in the downgrade-vulnerable rating category over the years 2009-2019. The bar in grey is based on the spread difference, if positive, between non-downgrade-vulnerable firms and downgrade-vulnerable firms. This component of the subsidy is computed by multiplying the aforementioned spread difference by the average maturity and the total offering amount of the bonds in the downgrade-vulnerable BBB rating category over the years 2009-2019.

here, differences in the investor clientele and capital requirements between investment-grade and speculative-grade segments drive a big wedge in funding costs. ${ }^{5}$ In total, we estimate that the subsidy accruing to prospective fallen angels amounted to $\$ 307$ billion between 2009 and 2019.

We argue, and provide a conceptual framework for it in Appendix B, that such an exorbitant privilege in the form of a bond-market subsidy for prospective fallen angels can arise in equilibrium due to a higher investor demand for IG bonds, but within IG for riskier corporate bonds. This high demand induces prospective fallen angels to take on more debt and increase their risk-taking, an activity that does not attract a rating downgrade in normal times due to the sluggishness of rating agencies in adjusting ratings at the cusp of IG. Our

\footnotetext{
${ }^{5}$ For example, insurance companies face risk-based capital requirements for their holdings of corporate bonds. These requirements are progressively steeper with credit ratings, especially if the IG threshold is crossed (https://content.naic.org/sites/default/files/inlinefiles/Master\%20NAIC\%20Designation\%20and\%20Category\%20grid\%20-\%202020.pdf).
} 
empirical tests that tease out this chain of logic are structured in three parts.

First, we show that investors exposed to QE drive the demand for downgrade-vulnerable IG corporate bonds. We define investor-level time-varying QE exposure as the share of investor total treasury holdings that are purchased by the Federal Reserve. Exploiting the granularity of our bond holdings data, we compare, in each quarter, holdings of bonds issued by the same firm that are held by investors with a different exposure to QE. The correlation between the investor bond holdings and investor exposure to QE is more pronounced for (i) bonds issued by prospective fallen angels, and (ii) long-duration investors that invest mostly in IG bonds. ${ }^{6}$

Second, we show prospective fallen angels meet the QE-induced demand by IG investors by supplying bonds largely for the purpose of financing risky acquisitions. These M\&A deals allow prospective fallen angels to delay downgrades (the short-term probability of being downgraded to high-yield is close to zero for prospective fallen angels that conduct an M\&A transaction). Announcements of acquisitions are usually accompanied by rosy forecasts about synergies and growth, and, more importantly, a promise to reduce the debt taken on to finance the acquisition, which induces rating agencies to be more lenient with these firms. However, data indicate that these mostly end up being broken promises. The resulting buildup of vulnerability over the extended period of QE led to an unprecedented wave of fallen angels, who were downgraded often by multiple notches at the onset of the COVID-19 pandemic, almost entirely among those firms that engaged in M\&A (see Figure 5 and Figure 13).

Third, we show that the privilege of prospective fallen angels, and the related increase in their market share, adversely affects competing firms and therefore has real spillovers. Non-downgrade-vulnerable firms operating in an industry with a larger share of prospective fallen angels have lower employment growth rates, lower investment levels, lower sales growth

\footnotetext{
${ }^{6}$ In particular, the results appear to be driven by insurers with variable annuities and open-ended debt mutual funds, focused on IG bond investments. In addition to helping understand the mechanism behind the subsidy for prospective fallen angels, the within-firm test based on QE-exposure of different investors clarifies that it is unlikely that the bond-market subsidy we uncover is driven by a BBB-firm-level "error" in Altman Z"-score rendering it mistakenly as a downgrade-vulnerable firm.
} 
rates, and lower markups compared with non-downgrade-vulnerable firms operating in an industry with a lower share of prospective fallen angels. Crucially, we do not find negative spillover effects when focusing on the overall share of downgrade-vulnerable firms, highlighting that the spillover effects arise only from prospective fallen angels which enjoy the exorbitant privilege in bond markets from long-duration IG-focused QE-exposed investors.

The remainder of the paper is structured as follows. Section 2 discusses the related literature. Section 3 presents the data, our measure of downgrade vulnerability, and the definition of prospective fallen angels. Section 4 documents the rapid growth of the BBB-rated issuers after the global financial crisis. Section 5 documents that prospective fallen angels have benefited from a bond financing subsidy, especially during 2013-16. Section 6 shows that this subsidy originates in QE-driven investor demand for IG bonds. Section 7 documents the sizable increase in M\&A activity of downgrade-vulnerable firms (and prospective fallen angels in particular) and explains how this dynamic is consistent with an equilibrium response to the QE-induced demand riskier IG bonds. Section 8 discusses the industry spillovers of the subsidy enjoyed by prospective fallen angels. Section 9 concludes.

\section{Related literature}

Our findings contribute to four inter-related strands of literature.

First, we contribute to the literature on the transmission of QE. This large literature has documented the effect of QE on asset prices (e.g., Krishnamurthy and Vissing-Jorgensen (2011)), lending outcomes (e.g., Acharya et al. (2019); Luck and Zimmermann (2020); Rodnyansky and Darmouni (2017)), and firm financing constraints (e.g., Di Maggio et al. (2020); Foley-Fisher et al. (2016)). In terms of macroeconomic outcomes, Fabo et al. (2021) document that only half of the academic papers find a statistically significant effect of QE on output. Our paper documents QE-induced capital misallocation (especially once QE peaked but long rates were kept low for longer), an important unintended consequence that might contribute to financial vulnerability, such as the materialization of corporate bond market stress at the onset of the pandemic. In this vein, our paper is related to the speeches by Rajan (2013) and Stein (2013) who warned about the risks of QE in terms of excessive financial 
risk-taking; while they focused on likely distortions in the junk bond market, leveraged loan market, and real-estate investment trust (REIT) borrowings; our paper shows that distortions have materialized even in the space of downgrade-vulnerable investment-grade bonds.

Second, we contribute to the literature on capital misallocation and fragility in corporate borrowing markets. The documented vulnerability of the investment-grade bond market since 2009 is consistent with warning signs from academics and practitioners about the BBB market (Altman, 2020; S\&P Global, 2020a; Blackrock, 2020; Morgan Stanley, 2018a,b) and partly explains the large price drop of investment-grade corporate bonds at the onset of the COVID19 pandemic (Haddad et al., 2021; Boyarchenko et al., 2021; Altman, 2020). ${ }^{7}$ The special role of the BBB market is consistent with the role of fire sale (cliff) risk documented in the literature (Falato et al., 2021b,a; Gilchrist et al., 2020; Acharya and Steffen, 2020). More generally, our findings are related to the literature on the misallocation of bank credit (Caballero et al., 2008; Acharya et al., 2020) and of other forms of financing (Midrigan and Xu, 2014; Whited and Zhao, 2021) as well as the role of low interest rates on misallocation (Banerjee and Hofmann, 2018, 2020). Our findings also fit the broader historical evidence documenting that low credit spreads and credit growth increase the probability of crises (Krishnamurthy and Muir, 2020; Gilchrist and Zakrajsek, 2012; Greenwood et al., forthcoming).

Third, we contribute to the literature on the real effects of frictions in investor portfolio choice. Consistent with the framework in Vayanos and Vila (2021), a few recent papers document the role of bond investors in the transmission of monetary policy (e.g., Ahmed et al. (2021); Darmouni et al. (2021)). ${ }^{8}$ Our paper documents that the reliance of bond investors on the IG cutoff, and thus on credit ratings, has interacted with QE policies - especially via their impact on yields of long-duration assets - to create capital misallocation and buildup of vulnerabilities in the massive BBB corporate bond market.

\footnotetext{
${ }^{7}$ Haddad et al. (2021) show that the extreme price movements at the onset of the COVID-19 pandemic were mostly in the safer end of the investment-grade market, consistent with investors trying to liquidate a large set of positions in bonds. See also Ivashina and Vallée (2020) for an analysis of fragility and reaching-for-yield behavior in the leveraged loan market.

${ }^{8}$ See also Kubitza (2021) and Greenwood and Vissing-Jorgensen (2018) who analyze how the portfolio choice of insurance companies affect firms and the yield curve, respectively.
} 
Fourth, we contribute to the literature on credit ratings. A large body of literature has shown that credit ratings affect investors' portfolio choice (Guerrieri and Kondor, 2012; Cornaggia and Cornaggia, 2013; Iannotta et al., 2019; Baghai et al., 2020). Becker and Ivashina (2015) show that, within rating categories, investors reaching-for-yield might tilt their portfolio toward riskier assets. Goldstein and Huang (2020) show that, this behavior might, in equilibrium, induce credit rating agencies to inflate their ratings. Credit ratings inflation is discussed in, among others, Herpfer and Maturana (2021) who show that credit rating agencies are less likely and slower to downgrade firms with "performance-sensitive debt." Finally, our paper is also related to Aktas et al. (forthcoming) who show that investment-grade firms are concerned in their M\&A activity about acquisition-related downgrades; however, we find that such concern appear to be less in the case of prospective fallen angels due to QE-induced demand for their bonds and rating agency leniency.

\section{Identifying prospective fallen angels}

In this section, we describe our data and explain our strategy to identify downgrade-vulnerable firms, including prospective fallen angels. Section 3.1 describes our data sources and data construction. Section 3.2 introduces our definition of downgrade-vulnerable firms and presents evidence of substantial and increasing rating inflation for BBB-rated firms since 2009.

\subsection{Data}

Our main data set consists of firm-level, bond-level, and investor-level data from 2009 to 2019. See Appendix A for a detailed explanation of our data sources and data construction.

The firm-level data includes debt capital structure data, balance sheet information, and rating information. The debt capital structure data is from WRDS Capital IQ, which provides extensive capital structure information for over 60,000 public and private companies globally. The balance sheet data is from Compustat North America, which provides annual report information of listed American and Canadian firms. Rating information is from Refinitiv Eikon, which provides worldwide coverage on ratings from S\&P, Moody's, and Fitch. We follow Becker and Milbourn (2011) in mapping credit ratings into numerical values (see 
Appendix A). Lastly, we use ThomsonOne for mergers and acquisitions data. Combining these various data sources, we analyze 6,145 firms.

The bond-level data set consists of pricing information for the U.S. corporate bond market. For the primary market, we use Mergent Fixed Income Securities Database (FISD), a fixed income database that includes issue details of publicly-offered U.S. bonds. We examine 6,460 bond issues by 909 issuers. For the secondary market, we obtain data from TRACE, a database of real-time secondary market information on transactions in the corporate bond market. We examine 7,741 outstanding bonds issued by 1,146 firms. To compute primary and secondary market corporate bond spreads, we follow Gilchrist and Zakrajsek (2012) and compute the spread relative to the yield on a synthetic US treasury with the same cash flows as the corporate bond. In addition, we follow Faust et al. (2013) and further adjust the spreads of callable bonds to account for the influence of risk-free rates on the option value of these bonds. In our analysis of the COVID-19 crisis, we extend our data set to 2020.

The investor-level data is from eMAXX Bond Holders data from Refinitiv, a detailed data set of security-level holdings by individual investors at a quarterly frequency. We match this data with the Fed security-level holdings in the SOMA portfolio (this data is publicly available on the website of the New York Fed). We further match this data with issuer- and security-level data from the rest of our analysis and collapse holdings within an investor at the issuer-level. The investor-level data has information on 2,750 investors, mostly property and casualty insurance policies (934), mutual funds (800), life and health insurance policies (590), and annuities (223) covering investments in 1,442 corporate bond issuers.

\subsection{Downgrade-vulnerable firms}

We define downgrade-vulnerable firms based on the Altman Z"-score, a measure of credit risk calculated from income statement and balance sheet information (Altman, 2020). The Altman Z"-score is defined as:

$Z "=6.56 \times \frac{\text { Current Assets }- \text { Current Liabilities }}{\text { Total Assets }}+3.26 \frac{\text { Retained Earnings }}{\text { Total Assets }}+6.72 \frac{\text { EBIT }}{\text { Total Assets }}+1.05 \frac{\text { Book Value of Equity }}{\text { Total Liabilities }}$ 

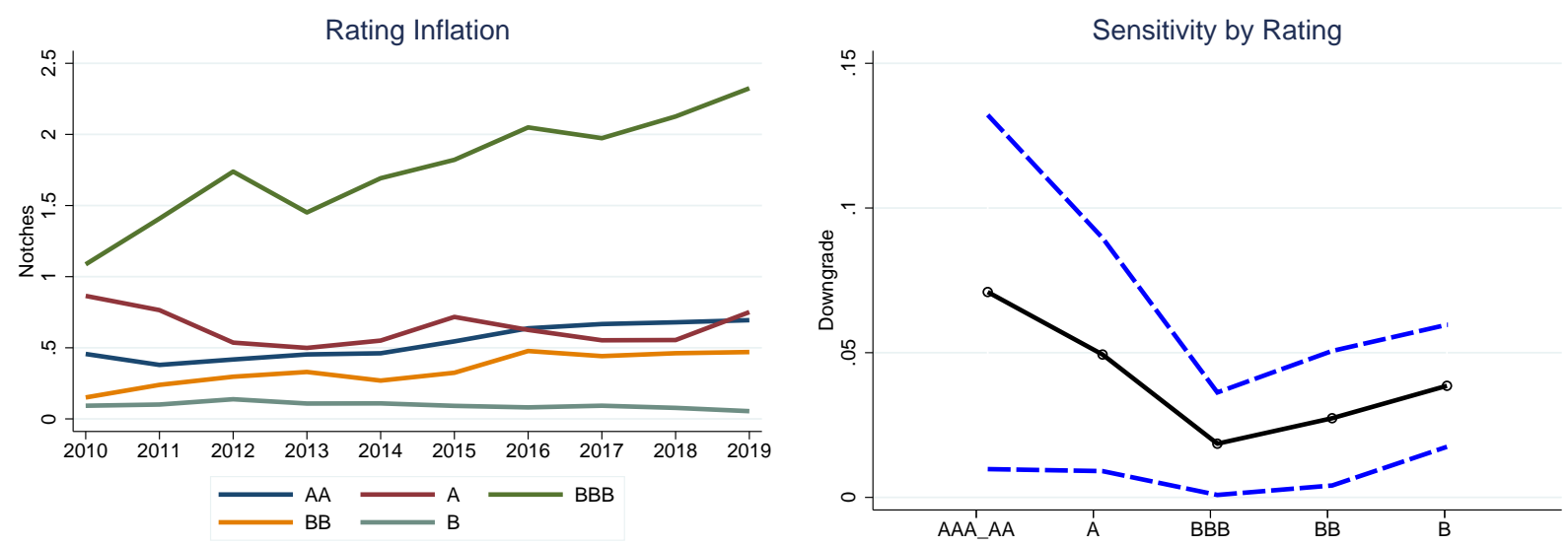

Figure 3: High and increasing credit ratings inflation for BBB-rated issuers. This figure shows credit ratings inflation across rating categories. The left panel shows credit ratings inflation based on firm Z"-score relative to Z"-scores of firms in lower ratings buckets. Credit ratings inflation is equal to zero if an issuer has a Z"-score above the median Z"-score of firms in the next lower rating category, otherwise credit ratings inflation is calculated as the number of notches between the issuer's credit rating notch (e.g., AA+, AA, AA-, A) and the credit rating notch implied by its Z"-score. The figure shows asset weighted credit ratings inflation in each year. The right panel shows how being classified as downgrade-vulnerable correlates with an actual downgrade across rating categories. The line shows, for each rating category, the estimated $\beta_{1}$ coefficient from the following regression specification: $Y_{i h t+1}=\beta_{1}$ Vulnerable $_{i h t}+\beta_{2} X_{i h t}+\mu_{h t}+\epsilon_{i h t+1}$, where $i$ is a firm, $h$ an industry, $t$ a year, $Y_{i h t+1}$ is a dummy equal to one in the case of a downgrade event in $t+1$ (to qualify as downgrade event, a firm must be downgraded by at least one rating category in year $t+1$, i.e. a firm that has a rating of $\mathrm{A}+, \mathrm{A}$, or $\mathrm{A}$ - is downgraded to at least $\mathrm{BBB}+$ ), Vulnerable is a dummy equal to one if a firm is downgrade-vulnerable in period $t, \mu_{h t}$ are industry-year fixed effects, and $X_{i h t}$ is a vector of controls (log of total assets, leverage, and interest coverage ratio). The error bars represent 95 percent confidence intervals, with standard errors clustered at the firm-level.

Specifically, we classify a firm as downgrade-vulnerable if its Z"-score is lower than the historical median Z" -score of the next lowest rating category. ${ }^{9}$ For example, a BBB-rated firm is classified as downgrade-vulnerable if its Z"-score is below the median Z"-score of BB-rated firms. A prospective fallen angel is a BBB-rated firm classified as downgrade-vulnerable.

We validate our measure of downgrade-vulnerability in Appendix D.1, where we show that (i) downgrade-vulnerable firms look worse along observables compared with non-downgradevulnerable firms (e.g., lower net worth, sales growth, investments, employment growth, interest coverage ratio, profitability, and higher leverage), (ii) downgrade-vulnerable firms are more

\footnotetext{
${ }^{9}$ We thank Ed Altman for providing us with these median "benchmark" Z"-scores for each rating category. The bond rating equivalents are determined by calibrating the Z"-scores to median values of each of the $\mathrm{S} \& \mathrm{P}$ rating categories for various years over the last 50 or more years (Altman, 2020). For a discussion on Z"-models, we refer to Altman (2018) and Altman et al. (2019).
} 
likely to be downgraded and to be assigned a negative credit watch or outlook relative to non-downgrade-vulnerable firms, and (iii) firms' performance deteriorates after becoming downgrade-vulnerable (decline in sales growth, investments, firm size, and employment).

The Z"-score documents a substantial and increasing ratings inflation for BBB-rated issuers. Credit ratings inflation is defined as zero for issuers that have a Z"-score above the median Z"-score of firms in the next lower rating category and equal to the difference between the issuer credit rating notch (e.g., AA+, AA, AA-) and the credit rating notch implied by its Z"-score otherwise. The left panel of Figure 3 shows that credit ratings inflation is highest for BBB-rated issuers, markedly increasing since 2009. The high ratings inflation for BBB-rated issuers is consistent with credit rating agencies' reluctance to downgrade BBB-rated firms to the speculative-grade market. The right panel shows that downgrade-vulnerable firms are more likely to be downgraded in each rating bucket, but that this correlation is the lowest for BBB-rated issuers. More precisely, the line shows the $\beta_{1}$ coefficient from the following regression specification, estimated separately for each rating category:

$$
\text { Downgrade }_{i h t+1}=\beta_{1} \text { Vulnerable }_{i h t}+\beta_{2} \mathrm{X}_{i h t}+\mu_{h t}+\epsilon_{i h t+1}
$$

where $i$ is a firm, $h$ an industry, $t$ a year, and Downgrade $i h t+1$ is a dummy equal to one in the case of a downgrade event in $t+1$ (to qualify as downgrade event, a firm must be downgraded by at least one rating category in year $t+1$, i.e. a firm that has a rating of $\mathrm{A}+$, $\mathrm{A}$, or A- is downgraded to at least $\mathrm{BBB}+$ ). This finding is consistent with other studies and anecdotal evidence. ${ }^{10}$

\footnotetext{
${ }^{10}$ For example, Bruno et al. (2016) show that Moody's avoids downgrading issuers of corporate bonds that are close to losing their investment-grade status. Investment bank analysts paint a similar picture of ratings inflation. For example, in 2018, a research note by Morgan Stanley noted that, “... where $55 \%$ of $B B B$ debt would have a speculative-grade rating if rated based on leverage alone. Meanwhile, interest coverage has declined steadily since 2014, particularly for BBB issuers..." (Morgan Stanley, 2018a).
} 


\section{Rising share and fragility of prospective fallen angels}

In this section, we present some motivating facts. Section 4.1 documents the sizable growth of the U.S. corporate debt market, mostly driven by BBB-rated issuers, following the global financial crisis. Section 4.2 shows that, during the same period, IG corporate issuers paid historically low bond yields while becoming considerably riskier - a dynamic particularly pronounced for BBB-rated issuers. Section 4.3 shows the unprecedented wave of fallen angels at the onset of COVID-19, before the Federal Reserve intervened to support this market.

\subsection{The growth of non-financial corporate debt}

After reaching $\$ 43$ trillion in 2008, U.S. private debt, which denotes the sum of households and non-profit organizations debt, non-financial business debt and domestic financial sector debt, decreased to $\$ 39$ trillion in 2011 and then steadily increased reaching $\$ 51$ trillion in 2020, a dynamic accelerated by the COVID-19 pandemic. While the deleveraging in 2008-11 was mainly driven by the financial and household sectors, the subsequent private leveraging cycle has been predominantly driven by the corporate non-financial sector. ${ }^{11}$ The steady increase of non-financial business debt, which increased from 10trillionin2008to17 trillion in 2020, has made it the largest private debt category today, equivalent to $82 \%$ of GDP in 2020. This increase in non-financial corporate debt in turn has been mostly driven by corporate bonds, with the stock outstanding increasing from around $\$ 3$ trillion in 2009 to around $\$ 6$ trillion in 2020, which in turn is almost entirely driven by bonds issued by BBB-rated firms, namely the lowest rated segment of the investment-grade bond market. This segment has tripled in size from around $\$ 0.7$ trillion in 2009 to more than $\$ 2$ trillion in 2018 and represents around $52 \%$ of all IG bonds outstanding, up from $33 \%$.

\footnotetext{
${ }^{11}$ Appendix $\mathrm{C}$ describes the evolution of aggregate private debt and the contribution of corporate debt since the Global Financial Crisis.
} 

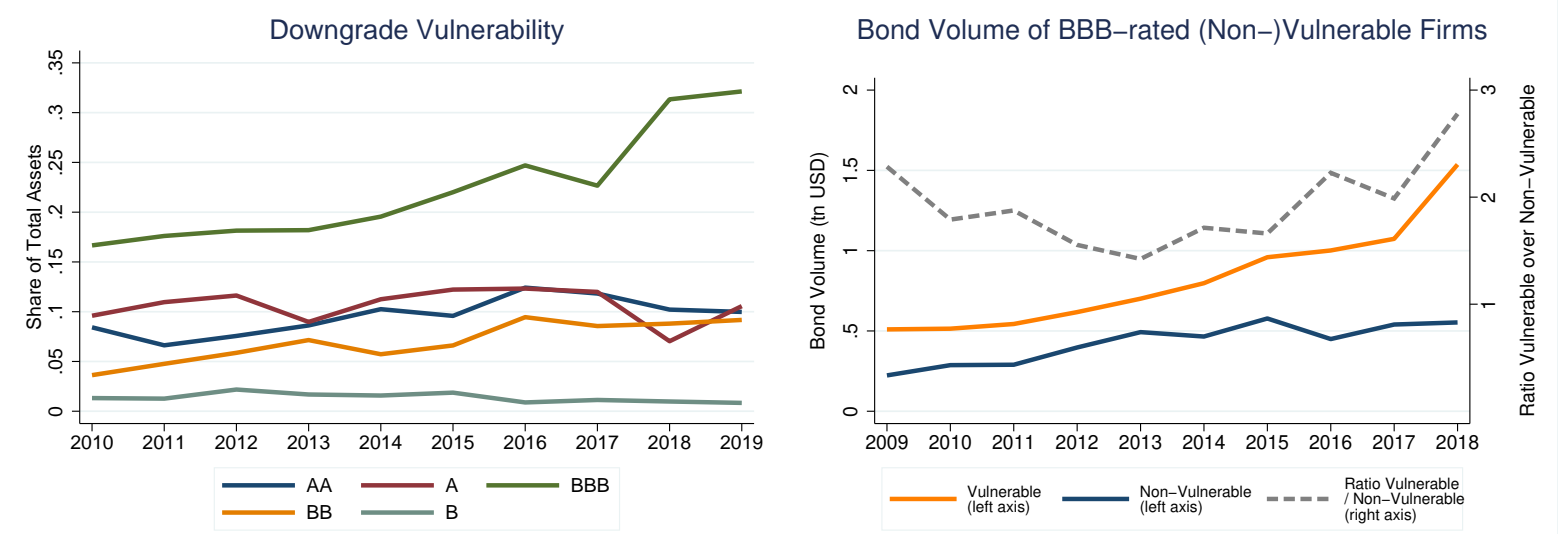

Figure 4: Increased downgrade-vulnerability of BBB-rated firms. This figure shows the increased downgrade-vulnerability of BBB-rated firms. The left panel shows the share of firms that are vulnerable to a downgrade based on the Z"-score by rating category, where firms are weighted by total assets. The right panel shows, within the $\mathrm{BBB}$ rating category, the share of bonds outstanding issued by vulnerable and non-vulnerable BBB-rated firms. The dashed line is the ratio between these two series.

\subsection{Firm risk}

The growth of the BBB segment of the bond market has been accompanied by a deterioration in the quality of BBB-rated firms and a substantial reduction in their bond financing costs. ${ }^{12}$ In Figure 4, we document the deterioration in issuer quality since 2009. The left panel shows the share of firms that are vulnerable to a downgrade based on the Altman Z"-score, as explained in Section 3.2. The figure shows that the share of firms that are vulnerable to a downgrade increased substantially in the BBB-market, but not in other markets, since 2013. The right panel confirms that the growth of the BBB market is driven by these prospective fallen angels. Since 2009, their stock of bonds outstanding tripled in size to $\$ 1.5$ trillion in 2018. During the same period, the non-downgrade-vulnerable BBB-rated segment increased only from $\$ 0.2$ to $\$ 0.5$ trillion. While the risk in the BBB segment increased substantially, bond spreads of BBB-rated firms decreased over our sample period (see Figure G.3).

\footnotetext{
${ }^{12}$ The deterioration of issuer quality has been discussed in industry pieces (Morgan Stanley, 2018a,b; Blackrock, 2020) and specialized papers (Celik et al., 2020; Altman, 2020; S\&P Global, 2020a) that warned about the risk of a wave of "fallen angels," namely a large number of downgrades of BBB-rated firms to the sub-IG (or "speculative-grade") market.
} 

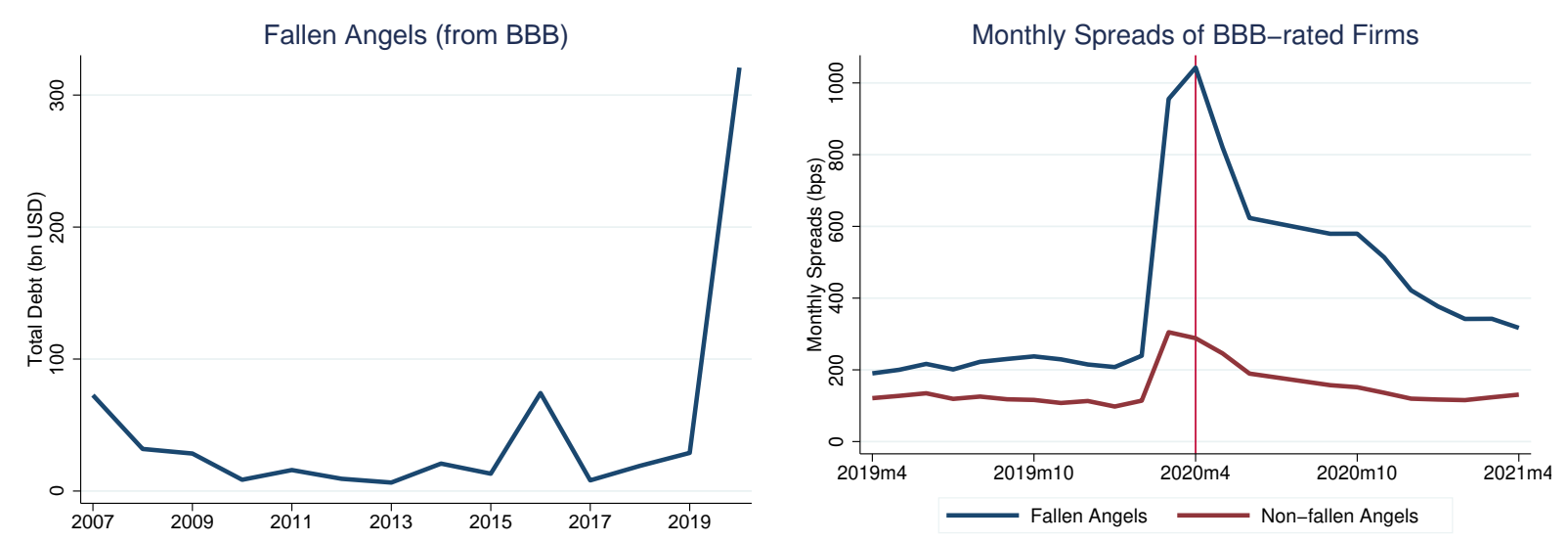

Figure 5: Risk materialization during COVID-19. This figure shows that the vulnerability of the BBB market materialized at the onset of the COVID-19 pandemic. The left panel shows total debt downgraded from BBB to speculative-grade from 2007 to 2020. The right panel shows monthly spreads of firms rated BBB in 2019. The blue line represents the spreads of fallen angels, namely firms downgraded during the COVID-19 pandemic. The red line represents the spreads of firms that maintained their IG status.

\subsection{Risk materialization during COVID-19}

The onset of the COVID-19 crisis precipitated an unprecedented wave of fallen angels until the Federal Reserve stepped in and extended its investment-grade corporate bond purchase program to support recently fallen angels. We interpret this episode as ex-post evidence of the increased vulnerability of BBB-rated firms, and of prospective fallen angels in particular. The evidence presented here is non-parametric. We provide formal tests in Appendix D.3.

The volume of debt downgraded from BBB to speculative-grade in just a few weeks at the beginning of 2020 was more than two times larger than the volume of similar downgrades during the entire Global Financial Crisis. The left panel of Figure 5 shows that, in 2020, the total debt of fallen angels amounted to an unprecedented $\$ 320$ billion.

The right panel shows the monthly spreads of firms that were rated BBB in 2019, distinguishing between firms that were downgraded at the onset of the pandemic (fallen angels) and those that maintained their BBB rating. We observe a sudden increase in the spreads of fallen angels in the first weeks of 2020. The difference in spreads partially reflects the downgrade-avoidance subsidy that prospective fallen angels benefited from by not being downgraded to the speculative-grade rating category. Only when the Federal Reserve expanded its corporate buying program on April 9, 2020 to include those issuers downgraded from BBB to fallen angels between March 22, 2020 and April 9, 2020, spreads declined. Some 
examples of firms eligible for the program are Ford Motor, Macy's, and Occidental Petroleum (S\&P Global, 2020b), all of which are classified as prospective fallen angels in our data.

\section{The exorbitant privilege}

In this section, we document the extraordinarily low bond financing costs of prospective fallen angels - BBB-rated downgrade-vulnerable firms - since 2009. This trend is particularly evident between 2013 and 2016, a period coinciding with the peaking of the Federal Reserve's balance sheet size as a result of its QE purchases and the Fed maintaining its balance sheet size roughly constant, keeping long-term rates "lower for longer".

First, we show that the drop in BBB bond spreads documented above (Figure 1) coincides with a marked decline in the spreads of BBB downgrade-vulnerable issuers relative to $\mathrm{BBB}$ non-downgrade-vulnerable issuers - a feature unique to the BBB rating relative to other ratings. Figure 6 shows the difference in secondary market spreads between downgradevulnerable and non-downgrade-vulnerable BBB issuers as well as those rated AAA-A and with $\mathrm{BB}$ ratings. The difference in the spread between downgrade-vulnerable and non-downgradevulnerable BBB-rated firms is (i) generally positive until the GFC; (ii) negative from 2013 to 2016; and, (iii) almost always smaller than the same difference for AAA-A and BB segments between 2013 and $2016 .^{13}$

Second, we confirm the existence of this prospective fallen angel privilege in bond markets using a formal test. In particular, we compare the bond spreads of downgrade-vulnerable and non-downgrade-vulnerable firms within a rating category by estimating the following

\footnotetext{
${ }^{13}$ Appendix section D.2 provides additional descriptive statistics on bond-level characteristics, showing that within each rating category secondary market spreads of bonds issued by downgrade-vulnerable firms are higher than those of their non-downgrade-vulnerable peers across the distribution. The one exception is the BBB segment where downgrade vulnerable firms have lower spreads across the distribution.
} 


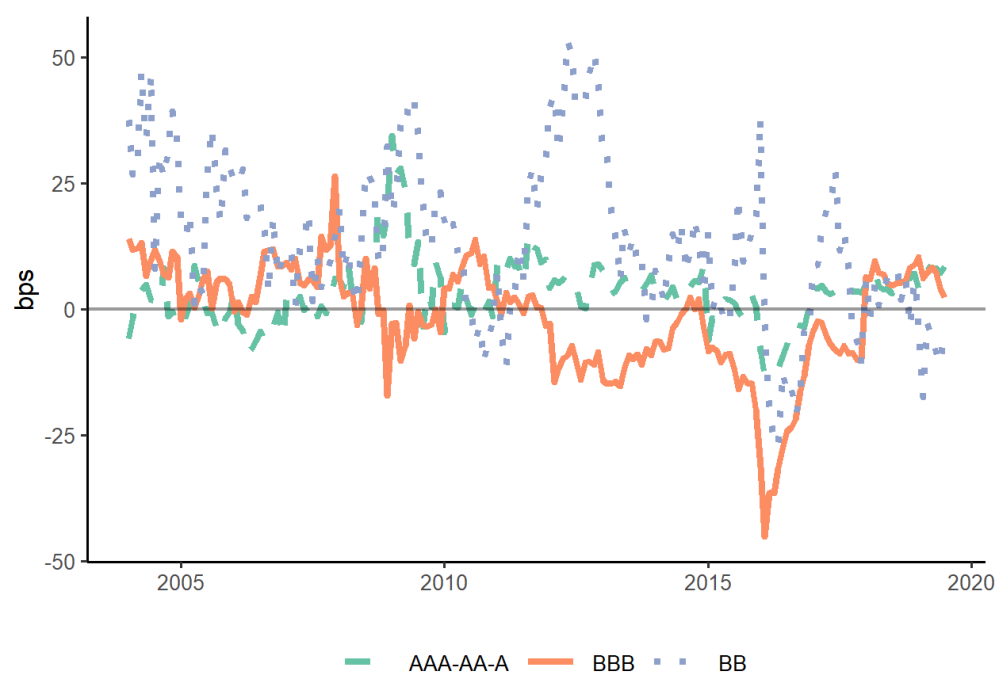

Figure 6: Bond spreads: downgrade-vulnerable minus non-downgrade-vulnerable firms. This figure shows the difference in secondary market spreads between downgrade-vulnerable and non-downgradevulnerable issuers for issuers rated AAA, AA and A (dashed line), BBB (solid line), and B (dotted line).

specification:

$$
\begin{aligned}
\text { Spread }_{b i t}= & \boldsymbol{\beta}_{\mathbf{1}} \text { Rating }_{i t}+\boldsymbol{\beta}_{\mathbf{2}} \text { Rating }_{i t} \times \text { Vulnerable }_{i t} \\
& +\boldsymbol{\delta} \mathbf{X}_{b t}+\boldsymbol{\gamma} \text { Liquidity }_{b t} \times \text { Rating }_{i t}+\boldsymbol{\mu}_{h t}+\epsilon_{b i t}
\end{aligned}
$$

where $\operatorname{Spread}_{b i t}$ is the spread (in basis points) of bond $b$ issued by firm $i$ in period $t$. We reiterate that we follow Gilchrist and Zakrajsek (2012) and compute spreads relative to the yield on a synthetic US treasury with the same cash flows as the corporate bond, and also Faust et al. (2013) to further adjust the spreads of callable bonds to account for the influence of risk-free rates on the option value of these bonds. As Becker et al. (2021) show, changes in credit quality can also influence the spread on bonds with a call option. We therefore include control variables to absorb the influence of changes in credit quality on callable bond spreads by including an indicator variable for callable bonds, another for bonds which are trading above par but below a price of 105 as well as the interaction of the two. ${ }^{14}$ Rating $_{i t}$

\footnotetext{
${ }^{14}$ As shown in Table D.3 around $90 \%$ of bonds in our sample are callable. Since 2010, the share has remained relatively constant. Our estimated regression coefficient suggests that when callable bonds trade
} 
is a vector of dummy variables corresponding to firm's $i$ rating in period $t$ and Vulnerable $i t$ is an indicator variable equal to one if issuer $i$ is classified as downgrade-vulnerable in year $t-1$ and year $t$ and retains the same rating across both years. ${ }^{15}$ We also include a vector $\mathbf{X}_{b t}$ of bond-level characteristics (remaining maturity, log of the offering amount and dummy variables taking the value of one for bonds with covenants, convertible bonds and senior bonds respectively). We also include control variables to capture the influence of bond liquidity on spreads by including bid-ask spreads which we allow to vary by rating bucket, Liquidity $_{b t} \times$ Rating $_{i t}$. We further include industry-year-month fixed effects $\boldsymbol{\mu}_{h t}$ to absorb unobserved time variation in spreads within an industry. Due to the relatively low number of bonds with a AAA rating, we combine AAA-rated and AA-rated firms into one category.

Table 1 presents the estimation results. The first column shows the estimation results in the full sample period. As expected, the uninteracted ratings terms show that bond spreads increase as the ratings deteriorate. The interaction terms between ratings and the vulnerable firm dummy variable show that in all rating categories, except BBB, downgrade-vulnerable firms have either higher financing costs (AAA-AA, BB, B, CCC) or statistically indistinguishable financing costs (A) compared with non-downgrade-vulnerable firms. Consistent with Figure 6 this pattern is reversed for BBB-rated firms as prospective fallen angels pay significantly lower financing costs than non-downgrade-vulnerable BBB firms. The second column shows the estimation results in the subsample running from 2013 to 2016 when the Fed maintained a more or less constant balance sheet size of $\$ 4.5$ trillion (see Appendix G.1). In this period, the funding privilege of prospective fallen angels increases in magnitude. The third and fourth columns show similar estimation results using primary market offering spreads as a dependent variable. The point estimates indicate that the vulnerable BBB funding subsidy is somewhat higher in primary bond markets. In Appendix D.4, we show that our baseline results are robust to using bond-level instead of issuer ratings as well as

close to the call barrier they trade at a 40 basis point discount to non-callable bonds, not far from Becker et al. (2021)'s estimates based on matched bonds from the same issuer.

${ }^{15}$ Results are qualitatively and quantitatively similar if we employ a less stringent definition and define vulnerable firms simply on whether they are classified as vulnerable in year $t$. 


\begin{tabular}{lcccc} 
& Spread & Spread & Offer Spread & Offer Spread \\
\hline A & $29.100^{* * *}$ & $30.471^{* * *}$ & 37.844 & -10.718 \\
& $(8.495)$ & $(8.087)$ & $(35.806)$ & $(28.191)$ \\
BBB & $81.404^{* * *}$ & $79.464^{* * *}$ & $106.468^{* * *}$ & $62.556^{* *}$ \\
& $(8.672)$ & $(8.547)$ & $(35.880)$ & $(28.740)$ \\
BB & $191.336^{* * *}$ & $182.127^{* * *}$ & $225.867^{* * *}$ & $200.985^{* * *}$ \\
& $(10.961)$ & $(13.514)$ & $(35.460)$ & $(26.455)$ \\
B & $337.734^{* * *}$ & $323.510^{* * *}$ & $310.352^{* * *}$ & $271.383^{* * *}$ \\
& $(17.427)$ & $(26.301)$ & $(35.608)$ & $(29.504)$ \\
CCC & $947.289^{* * *}$ & $1,049.530^{* * *}$ & $198.190^{* *}$ & $356.475^{* * *}$ \\
& $(93.020)$ & $(169.092)$ & $(89.791)$ & $(56.338)$ \\
Vulnerable $\times$ AAA-AA & 12.235 & $19.194^{* *}$ & 2.386 & -45.703 \\
& $(8.768)$ & $(9.079)$ & $(37.643)$ & $(30.406)$ \\
Vulnerable $\times$ A & 2.091 & -4.286 & $30.424^{* *}$ & $41.941^{*}$ \\
& $(4.963)$ & $(8.030)$ & $(12.836)$ & $(21.306)$ \\
Vulnerable $\times$ BBB & $-9.680^{* * *}$ & $-18.423^{* * *}$ & $-23.579^{* * *}$ & $-25.001^{*}$ \\
& $(3.599)$ & $(5.738)$ & $(8.296)$ & $(13.828)$ \\
Vulnerable $\times$ BB & $14.121^{*}$ & 14.068 & $29.676^{*}$ & 7.081 \\
& $(7.473)$ & $(11.776)$ & $(16.316)$ & $(28.776)$ \\
Vulnerable $\times$ B & $86.094^{* * *}$ & $78.941^{* *}$ & $43.206^{*}$ & 52.781 \\
& $(23.403)$ & $(35.557)$ & $(22.013)$ & $(40.616)$ \\
Vulnerable $\times$ CCC & $414.347^{* *}$ & 363.544 & & \\
& $(165.179)$ & $(237.879)$ & & $\checkmark$ \\
\hline Industry-Year-Month FE & $\checkmark$ & $\checkmark$ & $\checkmark$ & $\checkmark$ \\
Bond-level controls & $\checkmark$ & $\checkmark$ & $\checkmark$ & $\checkmark$ \\
\hline Sample & $2009-19$ & $2013-16$ & $2009-19$ & $2013-16$ \\
\hline Observations & 256,638 & 98,812 & 2,793 & 1,215 \\
R-squared & 0.651 & 0.626 & 0.836 & 0.824 \\
\hline
\end{tabular}

Table 1: The exorbitant privilege of prospective fallen angels. This table shows the estimation results of specification (2). The dependent variable in columns (1)-(2) is the secondary market bond spread. The dependent variable in columns (3)-(4) is the primary market bond spread. Bond spreads, measured in basis points. Vulnerable is a dummy equal to one if at the rating bucket of the bond, the firm's Altman-Z score is below that of the cut-off for the rating bucket below. Additional bond-level controls include residual maturity, amount outstanding and bid-ask spreads, coefficients on the latter are allowed to vary by rating. The specification also includes dummy variables for callable bonds, bonds with a price price above par but below a price of 105 and the interaction between the two variable to account for changes in credit quality affecting spreads on callable bonds. These control variables are included in the estimation but not reported for brevity. These specifications include industry-year-month fixed effects (2-digit SIC). Standard errors are clustered at the firm and year-month level. ${ }^{* *} \mathrm{p}<0.01,{ }^{* *} \mathrm{p}<0.05,{ }^{*} \mathrm{p}<0.1$.

including additional controls for bond liquidity based on the frequency with which the bond trades and whether the bond is on- or off-the-run.

Table 2 shows that this privilege is unique to the corporate bond market in the last decade. The first two columns use the (log) expected default frequency derived from equity markets at the 2-year and 5-year horizons as dependent variables, respectively. While we confirm that the estimated coefficients on the uninteracted terms increase monotonically as ratings 


\begin{tabular}{lccccc} 
& EDF 2Y & EDF 5Y & Spread & Loan spread & CDS \\
\hline BBB & $0.598^{* * *}$ & $0.472^{* * *}$ & $18.943^{* * *}$ & 9.698 & $51.875^{* * *}$ \\
& $(0.086)$ & $(0.068)$ & $(4.730)$ & $(18.914)$ & $(5.117)$ \\
BB & $1.493^{* * *}$ & $1.164^{* * *}$ & $87.178^{* * *}$ & $60.116^{* * *}$ & $178.520^{* * *}$ \\
& $(0.105)$ & $(0.083)$ & $(7.113)$ & $(22.451)$ & $(15.920)$ \\
B & $2.769^{* * *}$ & $2.121^{* * *}$ & $162.085^{* * *}$ & $119.756^{* * *}$ & $385.052^{* * *}$ \\
& $(0.122)$ & $(0.095)$ & $(10.288)$ & $(23.218)$ & $(37.442)$ \\
CCC & $4.129^{* * *}$ & $3.142^{* * *}$ & $359.317^{* * *}$ & $241.113^{* * *}$ & $659.209^{* * *}$ \\
& $(0.170)$ & $(0.134)$ & $(38.390)$ & $(74.555)$ & $(171.965)$ \\
Vulnerable $\times$ AAA-A & $0.191^{*}$ & $0.146^{*}$ & $5.964^{*}$ & -4.366 & -6.370 \\
& $(0.102)$ & $(0.084)$ & $(3.293)$ & $(25.558)$ & $(3.902)$ \\
Vulnerable $\times$ BBB & $0.208^{* *}$ & $0.140^{* *}$ & $10.053^{* *}$ & $17.776^{*}$ & $-17.401^{* * *}$ \\
& $(0.090)$ & $(0.068)$ & $(4.752)$ & $(9.359)$ & $(5.476)$ \\
Vulnerable $\times$ BB & $0.485^{* * *}$ & $0.349^{* * *}$ & $14.347^{* *}$ & 18.360 & $45.797^{*}$ \\
& $(0.096)$ & $(0.072)$ & $(5.857)$ & $(13.109)$ & $(24.363)$ \\
Vulnerable $\times$ B & $0.744^{* * *}$ & $0.561^{* * *}$ & $39.438^{* *}$ & $49.392^{* * *}$ & 16.786 \\
& $(0.108)$ & $(0.081)$ & $(19.369)$ & $(18.166)$ & $(61.811)$ \\
Vulnerable $\times$ CCC & 0.274 & 0.248 & $280.269^{* * *}$ & -95.201 & 33.954 \\
& $(0.190)$ & $(0.156)$ & $(67.662)$ & $(73.515)$ & $(107.732)$ \\
\hline Industry-Year-Month FE & $\checkmark$ & $\checkmark$ & $\checkmark$ & $\checkmark$ & $\checkmark$ \\
Bond-level controls & $\checkmark$ & $\checkmark$ & $\checkmark$ & $\checkmark$ & $\checkmark$ \\
\hline Sample & $2009-19$ & $2009-19$ & $2002-07$ & $2009-19$ & $2009-19$ \\
\hline Observations & 62,129 & 62,129 & 25,990 & 2,982 & 102,829 \\
R-squared & 0.767 & 0.789 & 0.776 & 0.715 & 0.743 \\
\hline
\end{tabular}

Table 2: The exorbitant privilege is unique to the bond market post-2009. This table shows the estimation results of specification (2). This table provides robustness checks on the vulnerable BBB subsidy in different markets and time periods. The dependent variable in columns (1)-(2) are the log expected default frequencies at the 2-year and 5-year horizon, respectively between 2010 to 2019. The dependent variable in column (3) is the secondary market bond spread in the pre-GFC period (2002-2007). The dependent variable in column (4) is the all-in-drawn spread for syndicated loans taken from DealScan. The dependent variable in column (5) is the spread on the CDS contract maturity matched to the corporate bonds sample in Table 1 column (1). The CDS contracts are interpolated to have the same remaining maturity as the corresponding bond. The specifications include industry-year-month fixed effects (2-digit SIC). Standard errors are clustered at the firm and year-month level. ${ }^{* * *} \mathrm{p}<0.01,{ }^{* *} \mathrm{p}<0.05,{ }^{*} \mathrm{p}<0.1$.

deteriorate, the funding advantage of prospective fallen angels disappears, suggesting that the exorbitant privilege is specific to the bond market. The third column shows that between 2002 and 2007 (the last business cycle before the GFC), prospective fallen angels did not benefit from a similar privilege in the corporate bond market. In fact, prospective fallen angels paid higher spreads in this period in line with other rating categories. The fourth column shows that prospective fallen angels did not enjoy a similar funding advantage in the 
syndicated loan market post $2010 \cdot{ }^{16}$ However, the fifth column of Table 2 suggests that credit default swap markets price a similar privilege for prospective fallen angels. In particular, the point estimate of the vulnerable BBB interaction term is negative and similar in magnitude to our baseline results in the first column of Table 1 for corporate bonds spreads.

Our interpretation is that the drivers of the prospective fallen angel privilege also influence the pricing of CDS contracts. In particular, an investor can gain credit exposure to a firm by either buying the bond or through a replication strategy of selling a CDS contract on the same firm and buying a US treasury. Two pieces of evidence suggests that the same influence in corporate bond markets also affects CDS markets. First, for insurance companies, whose participation in investment grade CDS markets is particularly relevant given the significantly higher capital requirements for sub-investment grade risks, the capital treatment of selling CDS in a replication strategy is the same as holding a corporate bond of the same rating according to the risk-based capital regulation issued by the National Association of Insurance Commissioners (NAIC). Second, replication strategies overwhelmingly account for insurance company exposure in CDS markets (around 75\%), see for example NAIC (2015). Finally, BIS derivative statistics also show that insurance companies have been consistent net sellers of CDS protection on non-financial corporates to dealers between 2009 and 2019 (see Table D10.1 of the BIS Derivative Statistics).

Taken together, these results suggest that the exorbitant privilege of prospective fallen angels is unique to corporate bond and replication (CDS) markets since 2009.

\section{The origins of the exorbitant privilege}

We now discuss the origins of the exorbitant privilege. Section 6.1 presents a conceptual framework that explains how the exorbitant privilege can arise in equilibrium due to a higher investor demand for riskier corporate bonds. Consistent with its prediction, Section 6.2

\footnotetext{
${ }^{16}$ Given a limited number of observations in the highest rating buckets AAA and AA, especially in the syndicated loan market data, we further combine AAA-A ratings into a single rating category.
} 
documents the role of QE in driving investors' demand for IG downgrade-vulnerable corporate bonds, especially those issued by prospective fallen angels.

\subsection{Theoretical framework}

Our explanation for the origin of the exorbitant privilege of prospective fallen angels relies on the interplay of three critical factors. First, a large demand for investment-grade bonds. Second, risk-taking behavior of investors within IG bonds, and in turn, of riskier issuers. Third, the sluggishness of credit ratings at the cusp of investment grade.

We present our framework in detail in Appendix B. Figure 7 outlines the intuition. By lowering yields on government bonds and mortgage-backed securities and, in turn, on (longterm) riskier assets, QE induces investors to adjust their portfolio choice (Gagnon et al., 2011; Krishnamurthy and Vissing-Jorgensen, 2011). In practice, investors such as life insurers seek out a greater quantity of riskier IG assets to meet their promised liabilities (e.g., variable annuities) as yields, as well as quantities of their traditional investments, are compressed by the Fed in QE programs. ${ }^{17}$ The high demand for corporate bonds reduces the cost of bond financing, inducing issuers to potentially take on more debt; in turn, more indebted issuers take on more risks, the outcome of a standard risk-shifting mechanism (Jensen and Meckling, 1976; John and John, 1993).

The extent of the increase in issuers' risk-taking, however, depends on whether these firms are vulnerable to a downgrade and on the sluggishness of credit rating agencies in downgrading firms, especially at the boundary of IG rating (BBB). Non-downgrade-vulnerable issuers are ex ante unlikely to be downgraded and thus benefit less from the sluggishness of credit rating agencies, relative to any additional risks they may take. By contrast, downgrade-vulnerable issuers are ex ante more likely to be downgraded and thus benefit more from the sluggishness

\footnotetext{
${ }^{17}$ This mechanism is consistent with anecdotal evidence. For example, the Financial Times reports that "insurance companies such as AIG and MetLife hold huge investment books, mainly consisting of bonds, to back the promises they make to their customers. Over the past decade, they have increasingly moved into riskier assets, according to Fitch, as yields in safer categories have fallen under aggressive easing policies from the world's central banks." Source: "Search for yield draws U.S. life insurers to risky places," Financial Times, February 21, 2019.
} 
Increase in debt financing

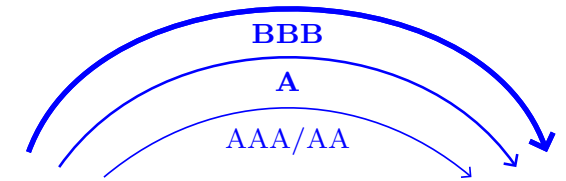

$\begin{array}{cc}\text { QE-induced } & \text { Increase in } \\ \text { demand for } & \text { risk-taking } \\ \text { IG corp. bonds } & \text { by IG corp. issuers }\end{array}$

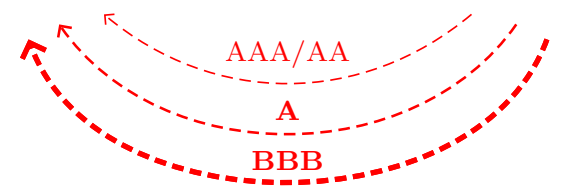

Sluggishness of credit ratings

- - - Mechanism at work for downgrade-vulnerable firms

Figure 7: Scheme of model intuition. This figure shows the intuition behind the model. QE induces an increase in demand for investment-grade corporate bonds causing, in turn, an increase in issuers' debt financing. The now more indebted issuers take on more risk. This effect (blue solid lines) is at work for all firms and stronger as we move down the rating categories within the investment-grade space. Given that credit rating agencies are sluggish in downgrading firms (especially those close the investment-grade threshold), the increased risk-taking by downgrade-vulnerable issuers is met again by high demand by investors sensitive to credit ratings. This effect (red dashed lines) is only at work for downgrade-vulnerable firms and stronger as we move down the rating categories within the investment-grade space.

of credit rating agencies if they take additional risks.

Figure 8 illustrates the main results of the framework presented in Appendix B, where we make the reduced-form assumption that investors subsidize (i) IG bonds relative to sub-IG bonds (preference for $I G$ ), and (ii) riskier bonds within each rating bucket, more so for riskier IG ratings (within- and across-ratings preference for risk). Together, these assumptions capture the observation that capital requirements and investment restrictions are lighter for IG relative to sub-IG bonds, that QE induces a preference for risk within IG-focused investors, and that rating agencies are sluggish to downgrade vulnerable firms especially at the cusp of the IG cutoff (Bruno et al., 2016).

The top panel shows bond yields as a function of firm quality, with firms grouped by credit ratings. Firms are ordered by decreasing quality on the x-axis; (i) the blue line, corresponding to the baseline economy, shows that bond yields increase as firms deteriorate in quality. There 

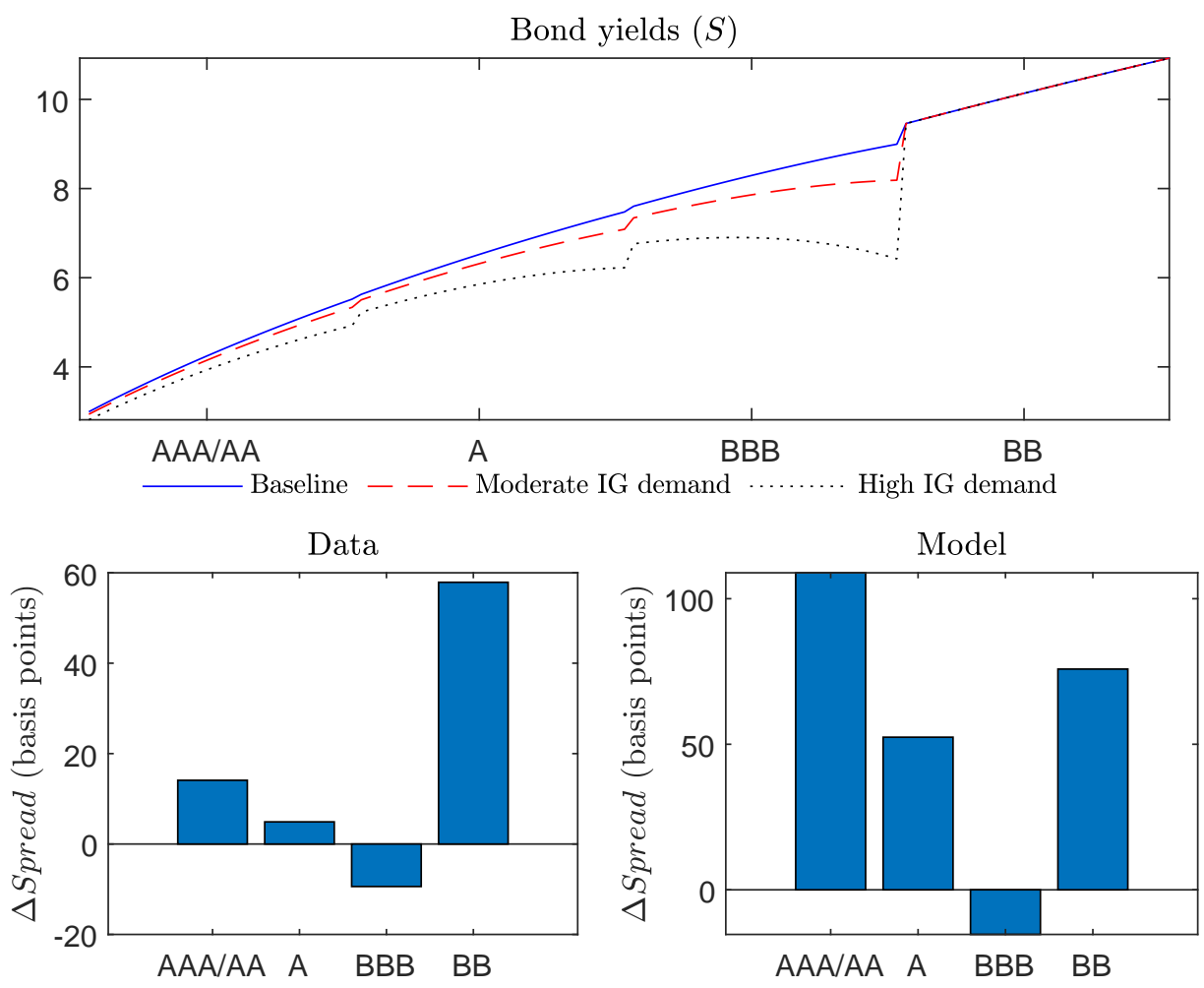

Figure 8: Corporate bond yields, model and data. The top panel presents the corporate yield curve with yields on the y-axis and firms sorted by quality, and grouped in credit ratings, on the $\mathrm{x}$-axis. The solid blue line, the red dashed line, and the black dotted line represent a baseline economy, an economy with moderate demand for IG corporate bonds, and an economy with high demand for IG corporate bonds. The bottom panel shows, for each rating category, the yield spread between downgrade-vulnerable and non-downgrade-vulnerable issuers. The bottom left panel is the mean of this spread over the entire sample period. The bottom right panel is the model spread in the high IG demand case.

is an additional jump at each rating cutoff, particularly pronounced at the investment-grade cutoff between BBB-rated and BB-rated firms; (ii) the dashed red line shows bond yields in an economy with a moderate preference for risk. The curve flattens and becomes more concave within each rating bucket, reflecting the equilibrium lower yields of downgrade-vulnerable firms; (iii) the black dotted line shows bond yields in an economy with a high preference for risk. The flattening and concavity of the yield curve is so pronounced that yields of bonds of prospective fallen angels fall below that of non-downgrade-vulnerable BBB-rated issuers.

The bottom panels compare the difference between the spread of downgrade-vulnerable firms and non-downgrade-vulnerable firms observed in the data in the full sample (left panel) and the one generated in our framework with a high preference for risk (right panel). In both cases, in the model and in the data, the difference is positive for all rating classes except for the BBB rating. This way, our framework qualitatively generates the exorbitant privilege of 
prospective fallen angels. ${ }^{18}$

\subsection{QE-driven demand by investment-grade investors}

Next, we document that investors exposed to the Federal Reserve QE programs drive the demand for IG corporate bonds, especially those issued by prospective fallen angels. This dynamic is entirely driven by investors that predominantly hold IG bonds and whose portfolio consists of mostly long-term bonds.

Exploiting our granular holdings data, we measure investors' exposure to QE and observe investors' holdings of bonds. We measure investor-level exposure to QE, merging our holdingslevel data with the Federal Reserve SOMA holdings data. Investor time-varying exposure to QE is defined as the share of investor total holdings that are held by the Federal Reserve in the SOMA Treasury portfolio, where holdings are weighted by the share of amounts outstanding held by the Federal Reserve. The idea is that investors with a substantial share of their security holdings held by the Federal Reserve at time $t$ are more affected by QE. Formally, we define the variable QE Exposure $k t$ as follows:

$$
\text { QE Exposure }_{k t}=\frac{\sum_{b}\left(\text { Holdings }_{b k t} \times S O M A_{b t}\right)}{\left.\sum_{b} H_{\text {oldings }}\right)}
$$

where $b$ is a security, $k$ is an investor, and $t$ is a date. $S O M A_{b t}$ is the share of Treasury security $b$ held by the Federal Reserve at date $t$. Holdings $s_{b k t}$ are the holdings of security $b$ held by investor $k$ at time $t$. This variable is calculated at a quarterly frequency. Figure 9 shows the time-series evolution of QE Exposure Ext $_{\text {. }}$

Figure 10 shows that high-exposure investors (above median QE exposure) increased

\footnotetext{
${ }^{18}$ There is an interesting parallel between such QE-induced capital misallocation and the zombie-lending related credit misallocation. In the latter, banks extend subsidized credit to distressed firms to gamble for resurrection and/or to not recognize them as non-performing assets (which would induce higher provisioning and capital requirements). In the former, each investor such as an insurance firm can be considered relatively atomistic; nevertheless, the sluggishness of credit rating downgrades can act as a coordinating mechanism whereby each such investor can search for yield to gamble over the "cliff" risk of IG to sub-IG downgrade. Materialization of the cliff risk may be associated with liquidation costs, in case of investors restricted to investing in IG, and/or higher capital requirements, in case of investors such as insurance companies.
} 


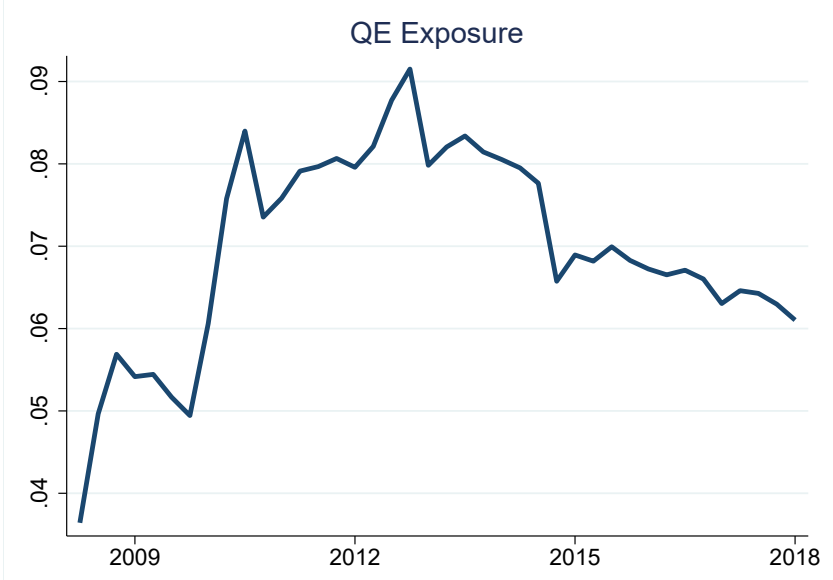

Figure 9: Investor exposure to QE. This figure shows the evolution of the cross-sectional mean of the QE Exposure $k t$ variable at a quarterly frequency. This variable is defined as the share of investor total holdings that are held by the Federal Reserve in the SOMA Treasury portfolio, where holdings are weighted by the share of amounts outstanding held by the Federal Reserve.

their holdings of investment-grade corporate bonds compared with low-exposure (below median QE exposure) investors starting around 2014. This differential dynamic is particularly pronounced in the BBB market and, within the BBB market, for prospective fallen angels. The top panel compares holdings by high-exposure and low-exposure investors in the BBB market (top left panel) and A/AA/AAA market (top right panel). High-exposure investors substantially increase their holdings starting in 2014 in both markets but more so in the BBB market. The two bottom panels further split holdings depending on whether bonds are issued by downgrade-vulnerable or non-downgrade-vulnerable firms. The substantial increase in holdings by high-exposure investors is almost entirely driven by holdings of downgrade-vulnerable firms. Again, this dynamic is more pronounced in the BBB market, particularly relative to holdings of non-downgrade vulnerable firms.

Next, we analyze investors' demand for bonds issued by prospective fallen angels by estimating the following specification:

$$
\text { Holdings }_{i k t}=\beta_{1} \mathrm{QE} \text { Exposure }_{k t} \times \text { Vulnerable }_{i t}+\eta_{k t}+\mu_{i t}+\epsilon_{k i t}
$$

where $k$ is an investor, $i$ is an issuer, and $t$ is a quarter. The dependent variable is the $\log$ of holdings by investor $k$ in year $t$ of bonds issued by issuer $i$. The independent variable of interest is the interaction between QE Exposure $k t$ and Vulnerable $_{i t}$, a dummy equal to one if 

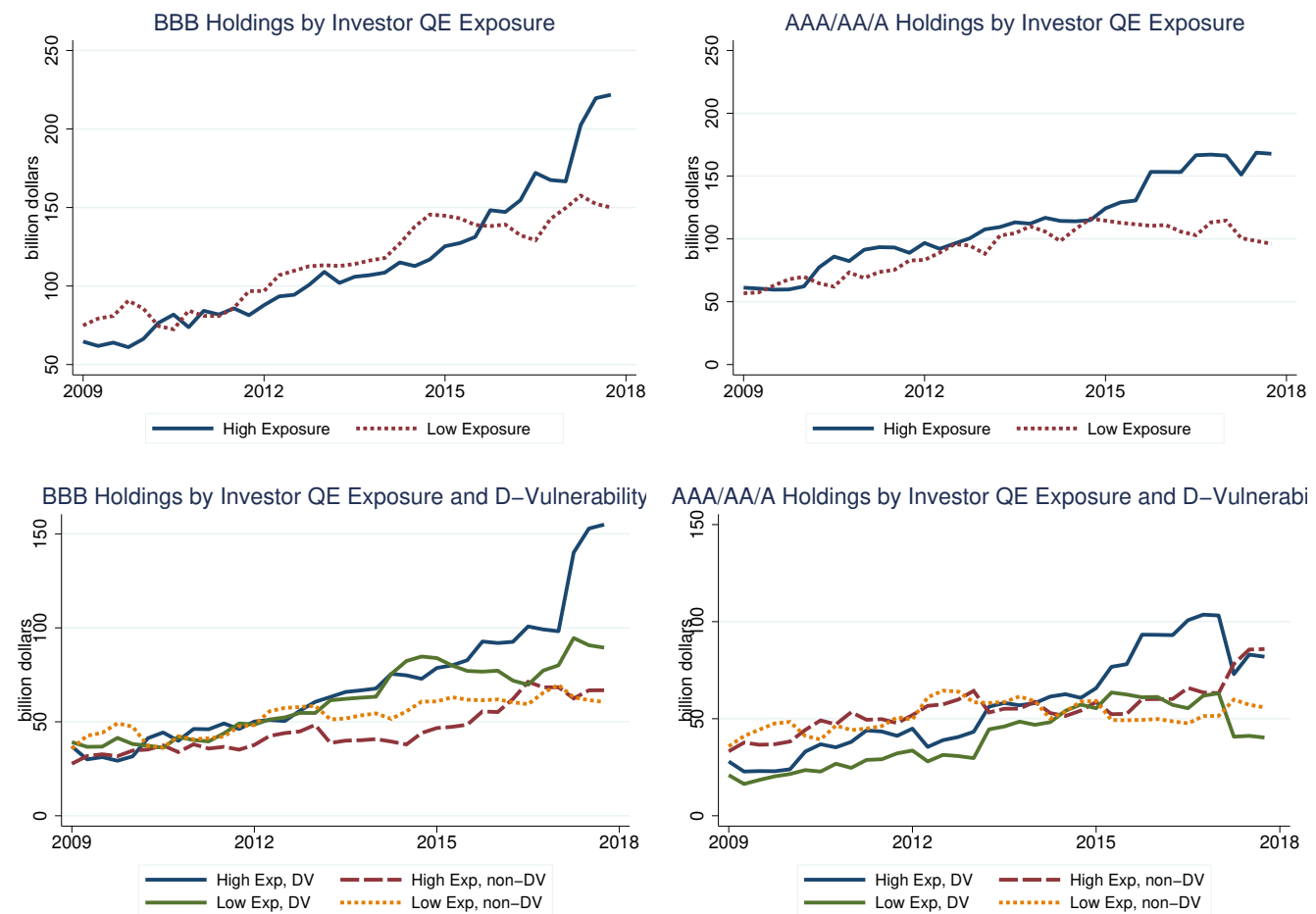

Figure 10: Investors' holdings of IG corporate bonds. This figure shows investors' holdings of investment grade corporate bonds, broken down by investor QE exposure, issuer rating, and downgradevulnerability. The top panels show holdings of bonds issued by BBB-rated issuers (top left panel) and A/AA/AAA-rated issuers (top right panel) by high-exposure (blue solid line) and low-exposure (red dotted line) investors. High-exposure investors have an above median exposure to QE. The bottom panels show holdings of bonds issued by BBB-rated issuers (bottom left panel, broken down by downgrade-vulnerability) and A/AA/AAA-rated issuers (bottom right panel, broken down by downgrade-vulnerability) by high-exposure and low-exposure investors.

issuer $i$ is downgrade-vulnerable in year $t$.

The coefficient of interest $\beta_{1}$ captures whether investors more exposed to QE hold more or fewer bonds issued by downgrade-vulnerable issuers compared with investors less exposed to QE. In the most stringent specification with investor-time and issuer-time fixed effects, we are effectively comparing bonds, at time $t$, issued by the same issuer that are held by investors with a different QE exposure. Investor-time fixed effects control for the potential differential portfolio choice by high- vs. low-exposure investors, with respect to downgradevulnerable and non-downgrade-vulnerable bonds, for reasons unrelated to QE. Issuer-time fixed effects control for the potential differential characteristics of downgrade-vulnerable and non-downgrade-vulnerable bonds (e.g., issuance volume) that might interact with the portfolio choice of high- vs. low-exposure investors for reasons, again, unrelated to QE.

Table 3 shows the estimation results. In Panel $\mathrm{A}$, the estimated coefficient $\beta_{1}$ is positive 


\begin{tabular}{|c|c|c|c|c|}
\hline \multirow{2}{*}{$\begin{array}{l}\text { PANEL A } \\
\text { QE Exposure }_{k t} \times \text { Vulnerable }_{i t}\end{array}$} & \multicolumn{4}{|c|}{ Holdings $_{i k t}$} \\
\hline & $\begin{array}{c}0.557^{* * *} \\
(0.143)\end{array}$ & $\begin{array}{c}0.539^{* * *} \\
(0.139)\end{array}$ & $\begin{array}{c}0.563^{* * *} \\
(0.145)\end{array}$ & $\begin{array}{c}0.549^{* * *} \\
(0.142)\end{array}$ \\
\hline \multicolumn{5}{|l|}{ Fixed Effects } \\
\hline Issuer $i$ & $\checkmark$ & $\checkmark$ & & \\
\hline Investor $k$ & $\checkmark$ & & $\checkmark$ & \\
\hline Time $t$ & $\checkmark$ & & & \\
\hline Investor $k$ - Time $t$ & & $\checkmark$ & & $\checkmark$ \\
\hline Issuer $i$ - Time $t$ & & & $\checkmark$ & $\checkmark$ \\
\hline Sample investors & Full & Full & Full & Full \\
\hline Sample issuers & Full & Full & Full & Full \\
\hline Observations & $4,491,046$ & $4,486,493$ & $4,489,965$ & $4,485,417$ \\
\hline R-squared & 0.508 & 0.559 & 0.528 & 0.578 \\
\hline PANEL B & \multicolumn{4}{|c|}{ Holdings $_{i k t}$} \\
\hline QE Exposure $_{k t} \times$ Vulnerable $_{i t}$ & $\begin{array}{l}-0.030 \\
(0.429)\end{array}$ & $\begin{array}{c}0.525^{* *} \\
(0.228)\end{array}$ & $\begin{array}{c}0.800^{* * *} \\
(0.204)\end{array}$ & $\begin{array}{c}-0.454^{* *} \\
(0.204)\end{array}$ \\
\hline Fixed Effects & & & & \\
\hline Investor $k$ - Time $t$ & $\checkmark$ & $\checkmark$ & $\checkmark$ & $\checkmark$ \\
\hline Issuer $i$ - Time $t$ & $\checkmark$ & $\checkmark$ & $\checkmark$ & $\checkmark$ \\
\hline Sample investors & Full & Full & Full & Full \\
\hline Sample issuers & $\mathrm{AAA} / \mathrm{AA}$ & $\mathrm{A}$ & $\mathrm{BBB}$ & HY \\
\hline Observations & 276,950 & 970,112 & $1,606,641$ & 853,576 \\
\hline R-squared & 0.731 & 0.678 & 0.623 & 0.521 \\
\hline
\end{tabular}

Table 3: Demand for bonds issued by prospective fallen angels. This table presents estimation results from specification (4). The unit of observation is investor $k$-issuer $i$-date $t$. The dependent variable is $\log \left(1+\right.$ Holdings $\left._{k i t}\right)$, where Holdings are holdings by investor $k$ in year $t$ of corporate bonds issued by issuer $i$ (thousands dollars). QE exposure ${ }_{k t}$ is defined in (3). Vulnerable $e_{i t}$ is a dummy equal to 1 if issuer $i$ is downgrade-vulnerable to a downgrade in date $t$. The uninteracted Vulnerable $e_{i t}$ and QE exposure $k t$ terms are included in the estimation but not reported for brevity. In Panel A, the specification is estimated in the full sample of investors. In Panel B, the specification is estimated in the full sample of investors and in the subsample of issuers based on their rating category. Standard errors double clustered at the investor $k$ level and issuer $j$ level reported in parentheses. ${ }^{* * *} \mathrm{p}<0.01,{ }^{* *} \mathrm{p}<0.05,{ }^{*} \mathrm{p}<0.1$.

and significant, suggesting that more exposed investors have a higher demand for bonds issued by downgrade-vulnerable issuers compared with less exposed investors. In Panel $\mathrm{B}$, we show sample splits based on issuer ratings. In the four columns, the estimation is run in the subsample of AAA/AA, A, BBB, and speculative-grade (or high-yield) issuers, respectively. The results show that the overall effect is driven by holdings of BBB-rated bonds. In unreported results, we find that the coefficients are somewhat stable throughout our sample period. Hence, the investor QE-exposure peaking in the middle of our sample period (see Figure 9) implies a rise in demand for bonds issued by prospective fallen angels 
roughly coinciding with the greater privilege in borrowing costs for these firms during in 2013-16.

Table 4 shows the estimation results for holdings of BBB-rated bonds in various subsamples of investors. The sample in Panel A only includes investors with a share of IG securities of at least $80 \%$ at each date $t$. The samples in Panel B and Panel $\mathrm{C}$ only include investors with a share of IG securities between $60 \%$ and $80 \%$ and smaller than $60 \%$ at each date $t$, respectively. In each panel, the first column only includes investors with a portfolio maturity of less than five years, the second column only includes investors with a portfolio maturity between five and seven years, and the third column only includes investors with a portfolio maturity of more than seven years, at each date $t$. These estimation results show that the results in Table 3 are entirely driven by investors holding a long-maturity portfolio and predominantly investment-grade securities. These findings are consistent with QE reducing long-term yields and the BBB-threshold affecting primarily those investors that mostly hold IG bonds.

Table G.1 shows summary statistics by investor type for the main types of investors represented in our data, namely insurers with variable annuities, (other) life and health insurers, property and casualty insurers, and open-ended mutual funds. Variable annuities are extremely exposed to QE and hold the longest maturity portfolio. This result is related to Koijen and Yogo $(2021,2022)$ that document the fragility of variable annuities in a low interest rate environment and how the minimum return guarantees have changed the primary function of life insurers from traditional insurance to financial engineering. Other life and health insurers also hold a long maturity portfolio but are less exposed to QE. Property and casualty insurers are highly exposed to QE but hold a somewhat short-term portfolio, mostly made of IG securities. Finally, open-ended mutual funds have a moderate exposure to QE, while also holding a long-term portfolio not too concentrated in the IG market. In unreported results available upon request, we find that the demand for prospective fallen angels in QE-exposed investors is driven in data by insurers with variable annuities and open-ended mutual fund investors/managers. It is interesting to note that during the COVID-19 outbreak, debt mutual funds experienced significant redemptions and contributed to corporate bond fire sales (see, among others, Haddad et al. (2021) and Falato et al. (2021a)). 


\begin{tabular}{lccc} 
PANEL A & \multicolumn{3}{c}{ Holdings $_{i k t}$} \\
\hline QE Exposure $k t$ × Vulnerable $_{i t}$ & -0.120 & 0.151 & $1.387^{* * *}$ \\
& $(0.230)$ & $(0.343)$ & $(0.361)$ \\
\hline Fixed Effects & $\checkmark$ & & \\
Investor $k$ - Time $t$ & $\checkmark$ & $\checkmark$ & $\checkmark$ \\
Issuer $i$ - Time $t$ & $\checkmark$ & $\checkmark$ & $\checkmark$ \\
\hline Sample issuers & BBB & BBB & BBB \\
Sample investors (portfolio duration) & $<5 \mathrm{Y}$ & $(5 \mathrm{Y}, 7 \mathrm{Y})$ & $>7 \mathrm{Y}$ \\
Sample investors (portfolio IG rating share) & $>0.8$ & $>0.8$ & $>0.8$ \\
\hline Observations & 147,710 & 135,026 & 268,882 \\
R-squared & 0.648 & 0.681 & 0.628 \\
\hline
\end{tabular}

\begin{tabular}{lccc} 
& \multicolumn{3}{c}{ Holdings $_{i k t}$} \\
\hline PANEL B & 0.236 & -0.072 & $0.765^{* * *}$ \\
& $(0.289)$ & $(0.354)$ & $(0.271)$ \\
\hline Fixed Effects & & & \\
Investor $k$ - Time $t$ & $\checkmark$ & $\checkmark$ & $\checkmark$ \\
Issuer $i$ - Time $t$ & $\checkmark$ & $\checkmark$ & $\checkmark$ \\
\hline Sample issuers & BBB & BBB & BBB \\
Sample investors (portfolio duration) & $<5 \mathrm{Y}$ & $(5 \mathrm{Y}, 7 \mathrm{Y})$ & $>7 \mathrm{Y}$ \\
Sample investors (portfolio IG rating share) & $(0.6,0.8)$ & $(0.6,0.8)$ & $(0.6,0.8)$ \\
\hline Observations & 106,479 & 149,007 & 623,447 \\
R-squared & 0.596 & 0.611 & 0.614 \\
\hline
\end{tabular}

\begin{tabular}{lccc} 
PANEL C & \multicolumn{3}{c}{ Holdings $_{i k t}$} \\
\hline QE Exposure \\
& \\
& 0.333 & 0.760 & 0.269 \\
& $(2.676)$ & $(0.737)$ & $(0.438)$ \\
\hline Fixed Effects & & & \\
Investor $k$ - Time $t$ & $\checkmark$ & $\checkmark$ & $\checkmark$ \\
Issuer $i$ - Time $t$ & $\checkmark$ & $\checkmark$ & $\checkmark$ \\
\hline Sample issuers & BBB & BBB & BBB \\
Sample investors (portfolio duration) & $<5 \mathrm{Y}$ & $(5 \mathrm{Y}, 7 \mathrm{Y})$ & $>7 \mathrm{Y}$ \\
Sample investors (portfolio IG rating share) & $<0.6$ & $<0.6$ & $<0.6$ \\
\hline Observations & 6,469 & 30,643 & 131,794 \\
R-squared & 0.698 & 0.558 & 0.659 \\
\hline
\end{tabular}

Table 4: Demand for bonds issued by prospective fallen angels, sample splits. This table presents estimation results from specification (4). The unit of observation is investor $k$-issuer $i$-date $t$. The dependent variable is $\log \left(1+\right.$ Holdings $\left._{k i t}\right)$, where Holdings are holdings by investor $k$ in year $t$ of corporate bonds issued by issuer $i$ (thousands dollars). QE exposure ${ }_{k t}$ is defined in (3). Vulnerable Vut $_{i t}$ is a dummy equal to 1 if issuer $i$ is downgrade-vulnerable to a downgrade in date $t$. The uninteracted Vulnerable $_{i t}$ and QE exposure $_{k t}$ terms are included in the estimation but not reported for brevity. All the regressions are estimated in the subsample of BBB-rated issuers. The results in Panel A, Panel B, and Panel C are estimated in the subsample of investors with a share of investment-grade bonds greater than $80 \%$, between $60 \%$ and $80 \%$, and smaller than $60 \%$, respectively. In all panels, the results in the first column are estimated in the subsample of investors with a portfolio maturity of less than five years, the results in the second column are estimated in the subsample of investors with a portfolio maturity of between five and seven years, and the results in the third column are estimated in the subsample of investors with a portfolio maturity of more than seven years. Standard errors double clustered at the investor $k$ level and issuer $j$ level reported in parentheses. $* * *$ $\mathrm{p}<0.01,{ }^{* *} \mathrm{p}<0.05,{ }^{*} \mathrm{p}<0.1$. 


\section{$7 \quad$ M\&A as an equilibrium response to investor demand}

In this section, we discuss how the sizable increase in M\&A activity of downgrade-vulnerable firms (and prospective fallen angels in particular) appears to be an equilibrium response to the QE-induced demand for bonds by IG-focused and long-duration investors. The core of our argument is that M\&A, mostly debt-funded, allows issuers to meet the high demand for IG bonds, while delaying an eventual downgrade given that credit ratings are extremely sluggish in the few years after M\&A deals, a dynamic unique to the BBB rating category.

Section 7.1 shows the increase in M\&A activity by prospective fallen angels. Section 7.2 documents the sluggishness of credit rating agencies in downgrading post-M\&A. Section 7.3 shows that the unprecedented wave of fallen angels in March 2020 was almost entirely driven by prospective fallen angels that engaged in M\&A.

\subsection{The increase in M\&A}

Figure 11 shows that downgrade-vulnerable firms, and prospective fallen angels in particular, drive the increase in M\&A activity since 2014 in the IG market. The top four figures focus on BBB-rated firms (first row) and A/AA/AAA-rated firms (second row). The left and right panels focus on downgrade-vulnerable and non-downgrade-vulnerable firms, respectively. M\&A deal volume increases substantially in 2014 for downgrade-vulnerable firms, whereas it stays roughly constant for non-downgrade-vulnerable firms. The two bottom figures plot the ratio of downgrade-vulnerable over non-downgrade-vulnerable M\&A deal volume, confirming that the increase in M\&A deal volume is more pronounced for prospective fallen angels. Figure E.1 shows that we do not observe these dynamics in the speculative-grade market. Figure E.2 shows the substantial increase in investment-grade bond issuance since 2013-15, was in large part to fund M\&A activity (we observe the bond issuance "purpose" in our data).

\subsection{The sluggishness of credit ratings post-M\&A}

Figure 12 shows two transition matrices, reporting the debt-weighted share of issuers transitioning across rating groups. The left matrix covers the full sample. The right matrix 

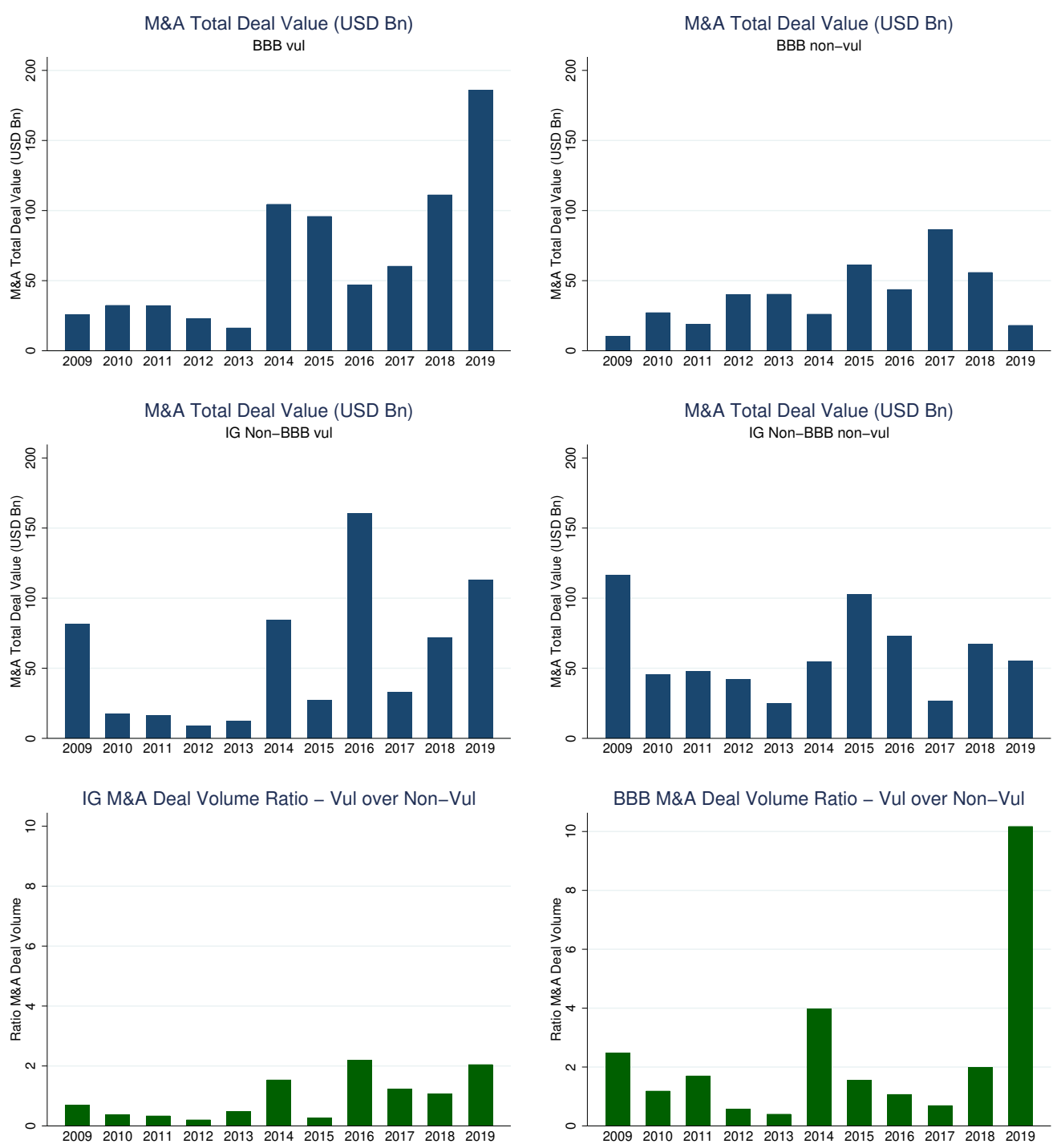

Figure 11: M\&A activity. This figure shows the M\&A activity by downgrade-vulnerable and nondowngrade-vulnerable investment grade issuers. The first row shows deal volume for downgrade-vulnerable (left) and non-downgrade-vulnerable (right) BBB-rated firms. The second row shows deal volume for downgrade-vulnerable (left) and non-downgrade-vulnerable (right) A/AA/AAA-rated firms. The third row shows the ratio of the total M\&A deal volume of downgrade-vulnerable firms over the total M\&A deal volume of non-downgrade-vulnerable firm in the AAA/AA/A (left) and BBB (right) rating categories. Figure E.1 presents the same charts for firms rated speculative-grade. 


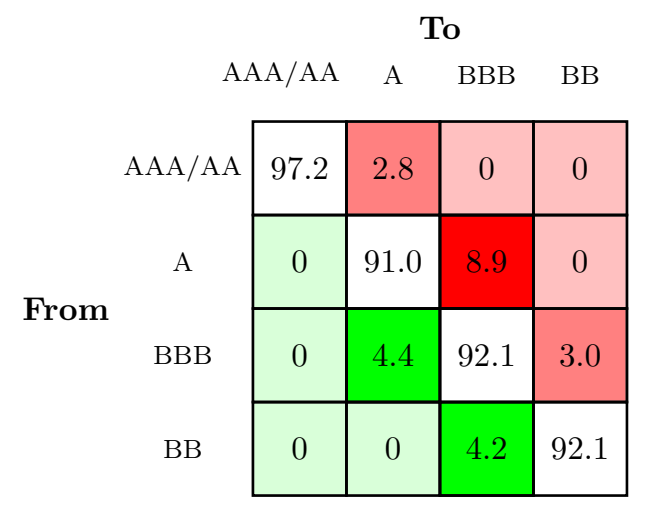

No M\&A

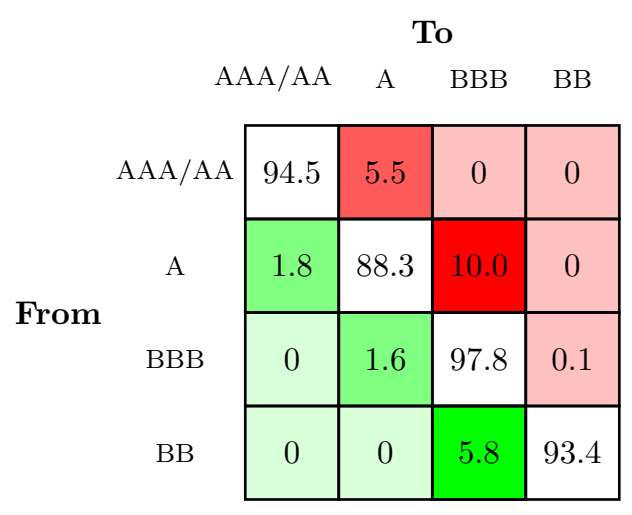

Post-M\&A

Figure 12: The sluggishness of credit ratings post-M\&A. This figure shows the debt-weighted share (in \%) of firms transitioning across issuer rating groups in one calendar year. The left matrix includes only firms without M\&A transaction within the last two years. The right matrix includes only firms within a two-year period after an M\&A transaction. The one-year transition probabilities are measured for the years 2011 to 2018, to account for the $t-2$ M\&A lag and to exclude the COVID-19 period. Sources: Thomson Reuters and Compustat.

only includes firms in the two-year period following an M\&A transaction. For example, the left matrix shows that 8.9 percent of A-rated firms are typically downgraded to BBB and that 3.0 percent of BBB-rated firms are typically downgraded to BB. The comparison of the two matrices reveals that, after M\&A, the probability of being downgraded increases for all IG-rating groups except BBB. BBB-rated firms are highly unlikely to be downgraded post-M\&A. In Section E.4, we provide a set of parametric tests to further link M\&A activity to a lower post-M\&A downgrade probability for prospective fallen angels.

This fact is consistent with anecdotal evidence as well as a large body of practitioners' research pieces which note that the announcement of an M\&A deal is almost always accompanied by rosy forecasts of synergies that will reduce costs and increase revenues and, even more importantly, a leverage-reduction plan. ${ }^{19}$ This plan is a promise to reduce the debt taken on to finance the acquisition in an attempt to convince credit rating agencies about

\footnotetext{
${ }^{19}$ For example, Morgan Stanley (2018a) states that “...ME $A$ has driven big increases in leverage and BBB debt outstanding. And while these companies may pledge to delever over time, those promises often don't materialize..." And, again, Morgan Stanley (2018b) writes that “...forward-looking assumptions often assume all goes well and earnings growth is strong. In reality, issuers have been slow to actually delever..."
} 

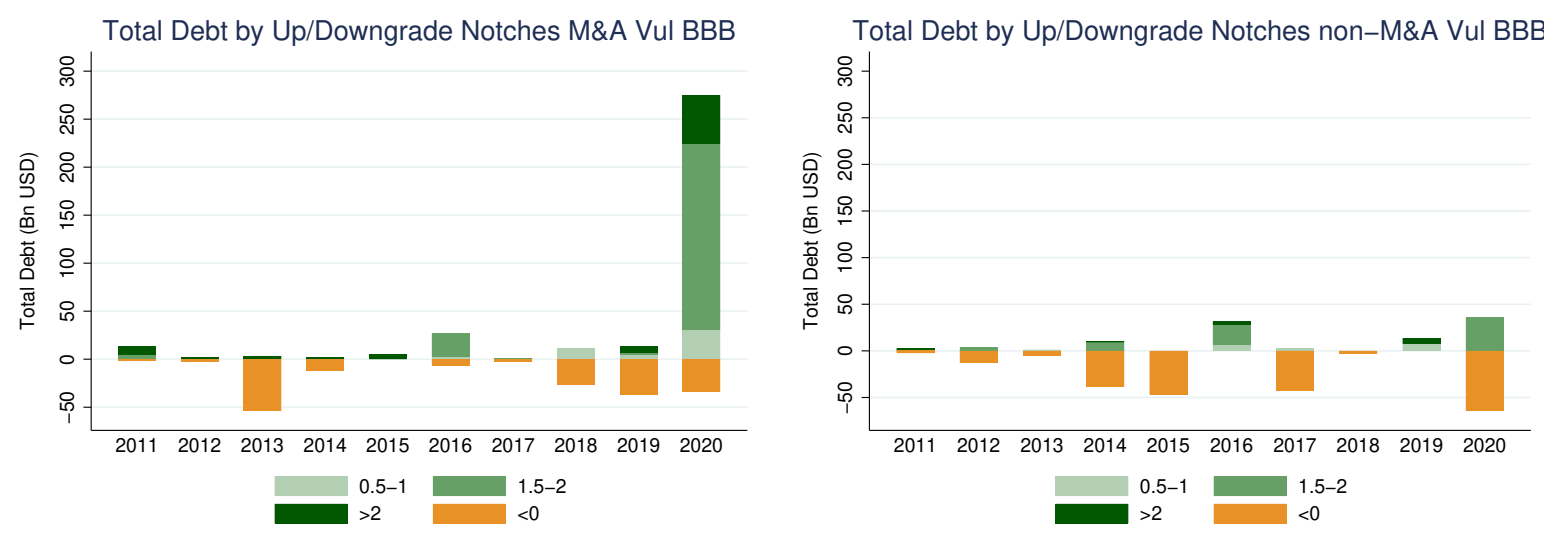

Figure 13: Downgrade materialization of (prospective) fallen angels. This figure shows the total debt of vulnerable BBB-rated firms that has been upgraded and downgraded in the years 2011 to 2020 . The downgraded debt is grouped according to their downgrade severity. The downgrade severity is measured by the number of notches a firm is being downgraded, and is subdivided into three broad categories: 0.5-1, $1.5-2,>2$ notches, as reflected by the green shades. The upgraded debt is shown by the orange bars, and is represented by the notches below zero. The left-hand panel plots the total amount of up/downgraded debt for vulnerable BBB firms that have conducted an M\&A since the year that they have become vulnerable. The right-hand panel shows the total amount of up/downgraded debt for firms that have not conducted an M\&A since the year that they have become vulnerable.

the issuer future prospects. Figure E.4 shows that this promise is often broken, consistent with opinions by market participants.

\subsection{Fallen angels at the onset of COVID-19}

Figure 13 shows the yearly debt volume that has been downgraded (upgraded) from downgradevulnerable BBB firms to a lower (higher) rating category. The two panels separate the debt volumes for the firms that engaged in M\&A (left panel) and firms that did not engage in M\&A (right panel). The green bar in Figure 13 shows that the debt downgraded from BBB to speculative-grade in 2020 was almost entirely driven by firms that engaged in M\&A. The different shades indicate the severity of the downgrade (number of notches). The much larger amount of downgraded debt and the number of rating notch downgrades of prospective fallen angels compared to their non-downgrade-vulnerable peers in 2020 is remarkable. Figure E.5 shows a similar pattern when looking at the number of issuers downgraded, not weighted by debt volume.

In Appendix E.2, we complement this ex-post evidence with ex-ante evidence where we show that prospective fallen angels (i) engage in relatively larger M\&A transactions compared 
to other rated firms, (ii) substantially increase their total debt without a comparable increase in profitability post-M\&A, and (iii) experience negative cumulative abnormal returns around the $\mathrm{M} \& \mathrm{~A}$ announcement date (not the case for non-downgrade-vulnerable BBB-rated issuers). ${ }^{20}$

\section{The cost of the subsidy}

In this section, we discuss the magnitude (Section 8.1) of the direct subsidy enjoyed by prospective fallen angels and one dimension of its indirect economic cost (Section 8.2).

\subsection{Quantifying the subsidy for prospective fallen angels}

In the Introduction, we claimed that prospective fallen angels benefited from a $\$ 307$ billion subsidy from 2009 to 2019. In this section, we explain this calculation and present additional evidence supporting this aggregate magnitude.

The subsidy enjoyed by prospective fallen angels has two components. First, a withinrating subsidy component originating from the fact that prospective fallen angels pay lower bond financing costs than non-downgrade-vulnerable BBB-rated firms. Second, a downgradeavoidance component originating from the fact that prospective fallen angels, by not being downgraded, avoid paying the much higher financing costs of speculative-grade issuers. This second component is also enjoyed by downgrade-vulnerable firms in other rating buckets as our definition of downgrade-vulnerable firms mechanically implies that these firms should be downgraded, according to their Z"-score, to the next lowest rating bucket.

The right panel of Figure 2 shows the within-rating subsidy (grey bar) and the downgradeavoidance subsidy (green bar) for ratings ranging from AAA-AA to BB. The within-rating subsidy is the bond spread between non-downgrade-vulnerable and downgrade-vulnerable firms with the same rating, multiplied by the average maturity and the total offering amount of the bonds in the downgrade-vulnerable rating category over the years 2009-19. The

\footnotetext{
${ }^{20}$ In Appendix E.3, we also show that the low bond financing costs of prospective fallen angels is particularly pronounced for issuers engaging in M\&A activity.
} 


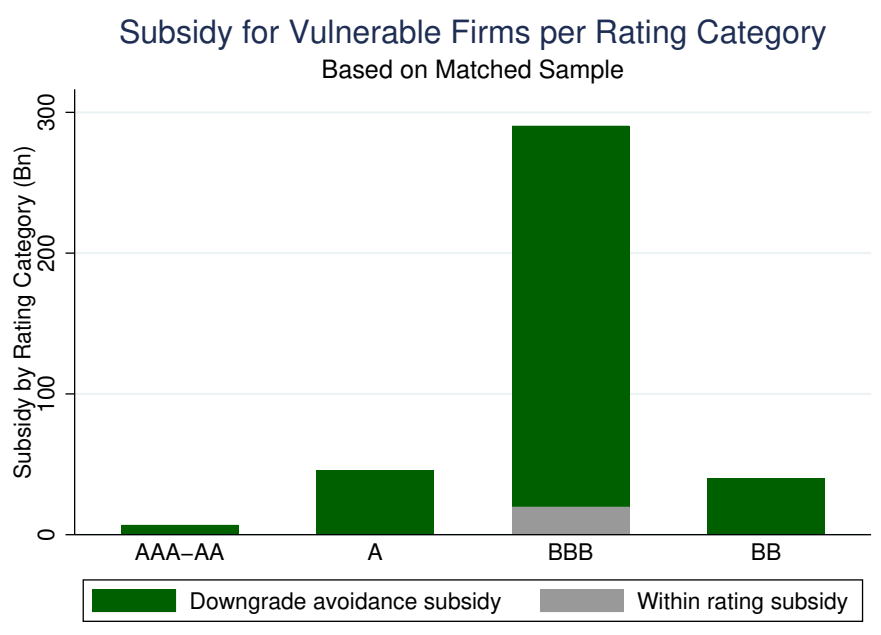

Figure 14: Bond market subsidy, robustness. This figure shows the bond market subsidy enjoyed by firms rated AAA-AA, A, BBB, and $\mathrm{BB}$. The green bars denote the downgrade-avoidance subsidy, calculated as, for each rating, the mean difference between the offering spread of downgrade-vulnerable firms and matched firms in the next lowest rating category in a given year, then multiplied by the average bond maturity and the total offering amount of the bonds in the downgrade-vulnerable rating category in a given years, summed over the years 2009-19. The grey bar denotes the within-rating subsidy for prospective fallen angels (BBB downgrade-vulnerable firms). The latter is calculated as in the right panel of Figure 2, i.e. the bond spread between non-downgrade-vulnerable and downgrade-vulnerable firms, multiplied by the average maturity and the total offering amount of the bonds in the downgrade-vulnerable rating category over the years 2009-19.

downgrade-avoidance subsidy is, for each rating, the difference between the mean offering spread of downgrade-vulnerable and non-downgrade-vulnerable firms in the next lowest rating category, then multiplied by the average bond maturity and the total offering amount of the bonds in the downgrade-vulnerable rating category over the years 2009-19.

Figure 14 complements this exercise with a more rigorous calculation of the "downgradeavoidance" subsidy. Specifically, we match each bond of a downgrade-vulnerable firm to bonds of firms in the next lowest rating category, within the same industry-year. We then choose the closest match, based on the firm's Z"-score, the bond maturity, and the bond offering amount. We rank the matches using the Mahalanobis norm, which measures the distance between the firm and bond characteristics accounting for the variance of individual characteristics and the covariances between characteristics, as is standard in literature (e.g., Chernenko and Sunderam (2012)). To safeguard the accuracy of our procedure, we restrict our sample to the matched bonds that have a score lower than 0.2 , as this threshold leads 
the firm and bond characteristics to not be statistically different. ${ }^{21}$

This methodology confirms that over the period 2009 to 2019, the bond financing costs of prospective fallen angels would have risen by $\$ 290$ billion if prospective fallen angels had been downgraded - a magnitude close to the one discussed in the Introduction. Moreover, Figure 14 shows that firms rated AAA-AA, A, and BB benefit from a much smaller subsidy, well below $\$ 50$ billion over the same sample period.

\subsection{Spillovers to competing firms}

In this section, we show (i) that the market share of prospective fallen angels increases substantially in our sample period, and especially since 2013-14, largely driven by M\&A and (ii) that non-downgrade-vulnerable firms are negatively affected by the presence of prospective fallen angels in their market.

Figure 15 shows the increase in market shares by prospective fallen angels. The top left panel shows the evolution of market shares by issuer rating, highlighting the rapid increase in BBB-rated issuers' market share starting from around 2014. The top right panel further breaks down each rating category into the downgrade-vulnerable and non-downgrade-vulnerable groups. The entire increase in BBB-rated issuers' market share is driven by prospective fallen angels. Figure E.3 further shows that the increase in market share of BBB-rated firms from 2014 to 2019 has been driven by prospective fallen angels engaging in M\&A.

The possible spillover we investigate is akin to the congestion externality documented in the context of zombie lending. Hence, we follow that literature (most notably Caballero et al.

\footnotetext{
${ }^{21}$ To ensure the robustness of our estimated subsidy for the prospective fallen angels, we measure the mean difference between the offering spread of bonds issued by downgrade-vulnerable BBB firms in a given year and the offering spread of bonds issued by BB firms in the same industry-year across different score cut-offs. In Appendix F, we show that changing the score cutoff does not result in material differences in the relative spreads, and thus does not lead to large differences in the total subsidy estimated.
} 

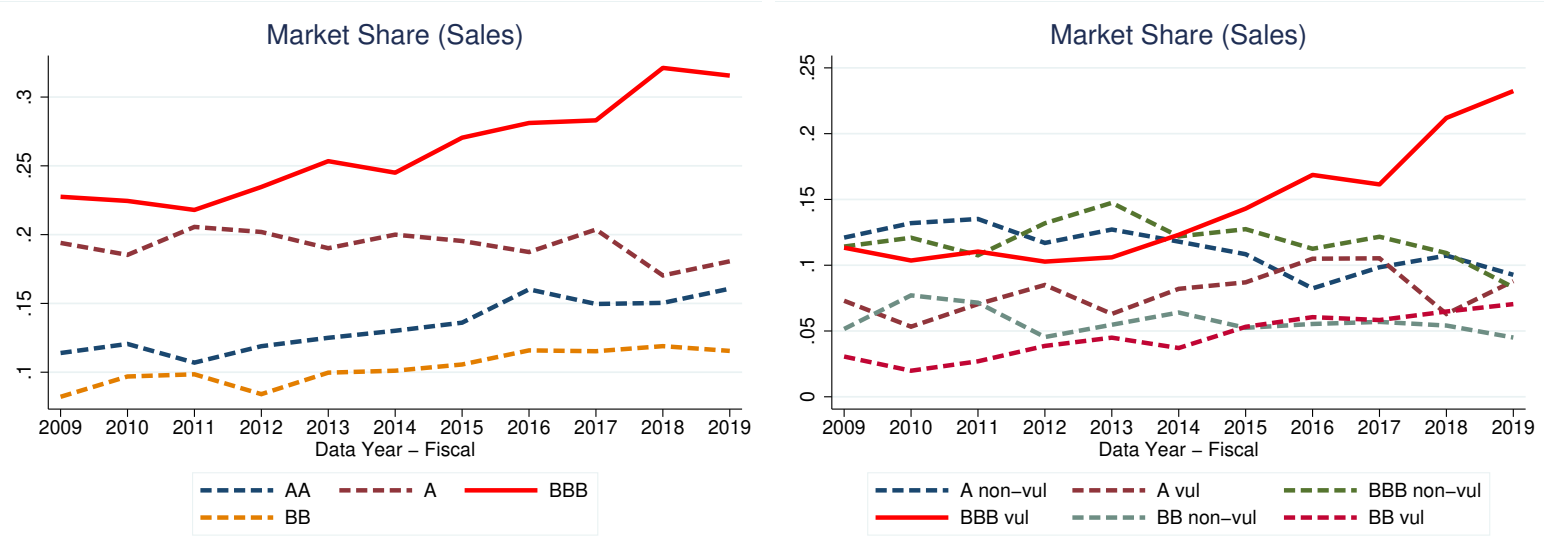

Figure 15: The increase in market share of prospective fallen angels. This figure shows the evolution of firm market share (share of sales in an industry, weighted by the relative size of the respective industry). The left panel includes all firms, grouped by credit rating from AA to BB. The right panel distinguishes between downgrade-vulnerable and non-downgrade-vulnerable firm within each rating.

(2008)) and estimate the following regression at the firm-year level:

$$
\begin{aligned}
Y_{i h t} & =\beta_{1} \text { Non-Vulnerable }_{i h t} \\
& +\beta_{2} \text { Non-Vulnerable }_{i h t} \times \text { Share Vulnerable } \mathrm{BBB}_{h t-1}+\eta_{h t}+\epsilon_{i h t},
\end{aligned}
$$

where $i$ is a firm, $h$ an industry, and $t$ is a year. The dependent variables are employment growth, investment, sales growth, and markups. We also include industry-year fixed effects. Our coefficient of interest, $\beta_{2}$, captures whether non-downgrade-vulnerable firms that operate in industries with a high share of prospective fallen angels perform differently than nondowngrade-vulnerable firms in industries with a lower share of prospective fallen angels.

Table 5 reports the estimation results. Panel A shows that, in the sample of rated firms, non-downgrade-vulnerable IG firms are negatively affected by the presence of prospective fallen angels. More precisely, the first two columns show that, while non-downgrade-vulnerable firms have on average higher employment growth rates and invest more, both employment and investment are impaired by the presence of prospective fallen angels. Moreover, these firms face lower sales growth and lower markups compared with firms that do not compete with a large share of prospective fallen angels. To assess the economic magnitude of these spillover effects, consider a one standard deviation increase in the share of vulnerable BBB-rated firms (0.144). This increase implies that non-vulnerable investment-grade firms face a 1.3pp lower 
Emp Growth CAPX Sales Growth Markup

Panel A: Rated Firms - Vulnerable IG

\begin{tabular}{lcccc}
\hline Non-vulnerable $\mathrm{IG}_{i h t}$ & $0.018^{* *}$ & $0.031^{* * *}$ & 0.005 & $0.633^{* *}$ \\
Non-vulnerable $\mathrm{IG}_{i h t} \times$ Share Vulnerable $\mathrm{BBB}_{h t-1}$ & $(0.009)$ & $(0.010)$ & $(0.008)$ & $(0.296)$ \\
& $-0.091^{* *}$ & $-0.149^{* * *}$ & $-0.099^{* *}$ & $-1.925^{* *}$ \\
& $(0.039)$ & $(0.048)$ & $(0.040)$ & $(0.890)$ \\
\hline Observations & 6,923 & 7,113 & 7,121 & 7,121 \\
R-squared & 0.112 & 0.318 & 0.278 & 0.256 \\
\hline
\end{tabular}

Panel B: Rated Firms - Placebo

\begin{tabular}{lcccc}
\hline Non-vulnerable $\mathrm{IG}_{i h t}$ & $0.033^{*}$ & $0.021^{* *}$ & 0.022 & 0.293 \\
Non-vulnerable $\mathrm{IG}_{i h t} \times$ Share Vulnerable & & & \\
& $(0.017)$ & $(0.011)$ & $(0.015)$ & $(0.231)$ \\
& -0.039 & -0.023 & -0.038 & 0.289 \\
Observations & $(0.030)$ & $(0.021)$ & $(0.028)$ & $(0.367)$ \\
R-squared & 6,923 & 7,113 & 7,121 & 7,121 \\
\hline
\end{tabular}

Panel C: All Firms

\begin{tabular}{|c|c|c|c|c|}
\hline Non-vulnerable $_{i h t}$ & $\begin{array}{c}0.040^{* * *} \\
(0.010)\end{array}$ & $\begin{array}{c}0.042^{* * *} \\
(0.011)\end{array}$ & $\begin{array}{c}0.040^{* * *} \\
(0.012)\end{array}$ & $\begin{array}{c}0.372^{* *} \\
(0.179)\end{array}$ \\
\hline 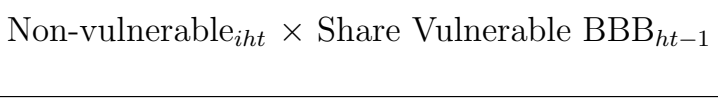 & $\begin{array}{c}-0.064^{* *} \\
(0.030)\end{array}$ & $\begin{array}{c}-0.101^{* *} \\
(0.046)\end{array}$ & $\begin{array}{c}-0.073^{* *} \\
(0.031)\end{array}$ & $\begin{array}{c}-0.900^{* *} \\
(0.432)\end{array}$ \\
\hline Observations & 26,009 & 27,471 & 26,978 & 26,872 \\
\hline R-squared & 0.042 & 0.191 & 0.045 & 0.133 \\
\hline Industry-Year FE & $\checkmark$ & $\checkmark$ & $\checkmark$ & $\checkmark$ \\
\hline Firm-level Controls & $\checkmark$ & $\checkmark$ & $\checkmark$ & $\checkmark$ \\
\hline
\end{tabular}

Table 5: Negative spillovers on other firms. This table presents estimation results from specification (5). The dependent variables are employment growth, CAPX/PPE, sales growth, and markups (defined as sales/cost of goods sold). Vulnerable (and non-vulnerable) is defined in Section 3.2. Panel A focuses on non-downgrade-vulnerable investment-grade firms and limits the sample to firms with a rating from at least one rating agency. Panel $\mathrm{B}$ focuses on all non-downgrade-vulnerable firms. Panel $\mathrm{C}$ focuses on non-downgrade-vulnerable firms using the entire sample of firms. Share Vulnerable BBB measures the asset-weighted share of downgrade-vulnerable BBB-rated firms in a two-digit SIC industry. Firm-level control variables include log of total assets, leverage, net worth, and an indicator variable for the rating bucket (AAA, AA, A, etc.). Standard errors clustered at the industry-level reported in parentheses. ${ }^{* * *} \mathrm{p}<0.01,{ }^{* *} \mathrm{p}<0.05$, $* \mathrm{p}<0.1$. 
employment growth, 2.1pp lower investment, and a 1.4pp lower sales growth.

Panel B shows that these spillover effects are not present when we replace the share of prospective fallen angels with the overall share of downgrade-vulnerable firms. This result confirms the uniqueness of prospective fallen angels, also when it comes to driving negative spillover effects. Panel C confirms our main results for the full sample of firms.

\section{Conclusion}

We document an exorbitant privilege in the form of a bond market borrowing cost subsidy for prospective fallen angels, namely firms on the cusp of the investment-grade cutoff. This subsidy, present since the Global Financial Crisis, peaked during 2013-16 when the Federal Reserve balance-sheet itself reached its pre-COVID peak of $\$ 4.5$ trillion. We find the subsidy to be driven by QE-induced demand for investment-grade bonds in IG-focused and longduration investors such as annuities. This demand, in turn, induces prospective fallen angels to engage in risky M\&A, exploiting the leniency of credit rating agencies in order to increase their market share with adverse spillovers on competing firms.

Our results suggest that although the growth of investment-grade bond segment may have been a desired consequence of $\mathrm{QE}$, the growing concentration of issuance in the riskiest investment-grade $(\mathrm{BBB})$ bucket also comes at a cost that may run counter to central bank objectives. First, the subsidised firms grow disproportionately large and become more fragile, as evidenced by the unprecedented wave of fallen angels that were downgraded by multiple notches at the onset of the COVID-19 crisis. Second, the resulting spillover effects force their competitors to reduce employment, investment, markups, and sales growth.

This capital misallocation cost of $\mathrm{QE}$ has not been documented hitherto, to the best of our knowledge, and may need to be factored in while considering the desirability, scale, scope, and duration of QE interventions in the future, as well as in the present discussions to normalize central bank balance sheet size given the extraordinary size of post-COVID QE programs. Indeed, the ongoing crash of IG-rating indices (during 2022), which seems to have outpaced that of high-yield indices, suggests that the impact of central bank interventions on the pricing and issuance of investment-grade corporate bonds are worthy of careful scrutiny 
also during the post-COVID period.

\section{References}

Acharya, V., M. Crosignani, T. Eisert, and C. Eufinger (2020): "Zombie Credit and (Dis-)Inflation: Evidence from Europe," Working Paper.

Acharya, V., T. Eisert, C. Eufinger, And C. Hirsch (2019): "Whatever it takes: The Real Effects of Unconventional Monetary Policy," Review of Financial Studies, 32, 3366-3411.

Acharya, V. And S. Steffen (2020): "The risk of being a fallen angel and the corporate dash for cash in the midst of COVID," Review of Corporate Finance Studies, 9, 430-471.

Ahmed, A., B. Hofmann, And M. Schmitz (2021): "Foreign Institutional Investors, Monetary Policy, and Reaching for Yield," Working Paper.

Aktas, N., D. Petmezas, H. Servaes, and N. Karampatsas (forthcoming): "Credit Ratings and Acquisitions," Journal of Corporate Finance.

Altman, E. I. (2018): "A fifty-year retrospective on credit risk models, the Altman Z-score family of models and their applications to financial markets and managerial strategies," Journal of Credit Risk, 14.

(2020): "COVID-19 and the Credit Cycle," Journal of Credit Risk, 16, 1-28.

Altman, E. I., E. Hotchkiss, And W. Wang (2019): Corporate financial distress, restructuring, and bankruptcy: analyze leveraged finance, distressed debt, and bankruptcy, John Wiley \& Sons.

Baghai, R., B. Becker, And S. Pitschner (2020): "The Use of Credit Ratings in Financial Markets," Working Paper.

Banerjee, R. And B. Hofmann (2020): "Corporate zombies: Anatomy and life cycle," Bank for International Settlements Working Papers, 1-28.

Banerjee, R. N. And B. Hofmann (2018): "The rise of zombie firms: causes and consequences," BIS Quarterly Review.

Becker, B., M. Campello, V. Thell, And D. Yan (2021): "Credit Risk and the Life Cycle of Callable Bonds: Implications for Corporate Financing and Investing," CEPR Discussion Papers 16239, C.E.P.R. Discussion Papers.

Becker, B. And V. Ivashina (2015): "Reaching for Yield in the Bond Market," The Journal of Finance, 70, 1863-1902.

Becker, B. And T. Milbourn (2011): "How did increased competition affect credit ratings?" Journal of Financial Economics, 101, 493-514. 
BLACKROCK (2020): "Assessing risks in the BBB-rated corporate bond market," Online, accessed 18 August 2020.

Boyarchenko, N., R. Crump, A. Kovner, and O. Shachar (2021): "Measuring Corporate Bond Dislocations," Federal Reserve Bank of New York Staff Reports.

Bruno, V., J. Cornaggia, And K. J. Cornaggia (2016): "Does Regulatory Certification Affect the Information Content of Credit Ratings?" Management Science, 62, 1578-1597.

Caballero, R. J., T. Hoshi, and A. K. Kashyap (2008): "Zombie Lending and Depressed Restructuring in Japan," American Economic Review, 98, 1943-77.

Çelik, S., G. Demirtas, And M. Isaksson (2020): Corporate bond market trends, emerging risks and monetary policy, OECD Capital Market Series, Paris.

Chernenko, S. And A. Sunderam (2012): "The real consequences of market segmentation," The Review of Financial Studies, 25, 2041-2069.

Cornaggia, J. And K. Cornaggia (2013): "Estimating the Costs of Issuer-Paid Credit Ratings," The Review of Financial Studies, 26, 2229-2269.

Darmouni, O., O. Giesecke, And A. Rodnyansky (2021): "The Bond Lending Channel of Monetary Policy," Working Paper.

Di Maggio, M., A. Kermani, And C. Palmer (2020): "How Quantitative Easing Works: Evidence on the Refinancing Channel," Review of Economic Studies, 87, 1498-1528.

Fabo, B., M. Jancokova, E. Kempf, And L. Pastor (2021): "Fifty Shades of QE: Comparing Findings of Central Bankers and Academics," Working Paper.

Falato, A., I. Goldstein, And A. Hortacsu (2021a): "Financial Fragility in the Covid-19 Crisis: The Case of Investment Funds in Corporate Bond Markets," Journal of Monetary Economics, 123, 35-52.

Falato, A., A. Hortacsu, D. Li, And C. Shin (2021b): "Fire-sale Spillovers in Debt Markets," Journal of Finance, 76, 3055-3102.

Faust, J., S. Gilchrist, J. H. Wright, And E. ZakrajŠSek (2013): "Credit Spreads as Predictors of Real-Time Economic Activity: A Bayesian Model-Averaging Approach," The Review of Economics and Statistics, 95, 1501-1519.

Foley-Fisher, N., R. Ramcharan, And E. Yu (2016): "The Impact of Unconventional Monetary Policy on Firm Financing Constraints: Evidence from the Maturity Extension Program," Journal of Financial Economics, 122, 409-429.

Gagnon, J., M. Raskin, J. Remache, and B. Sack (2011): "The Financial Market Effects of the Federal Reserve's Large-Scale Asset Purchases," International Journal of Central Banking, 7, 3-43. 
Gilchrist, S., B. Wei, V. Z. Yue, And E. ZakrajšEk (2020): "The Fed Takes on Corporate Credit Risk: An Analysis of the Efficacy of the SMCCF," NBER Working Papers 27809, National Bureau of Economic Research, Inc.

Gilchrist, S. AND E. Zakrajsek (2012): "Credit Spreads and Business Cycle Fluctuations," American Economic Review, 102, 1692-1720.

Goldstein, I. And C. Huang (2020): "Credit Rating Inflation and Firms' Investments," Journal of Finance, 75, 2929-2972.

Greenwood, R., S. Hanson, A. Shleifer, and J. Sorensen (forthcoming): "Predictable Financial Crises," Journal of Finance.

Greenwood, R. And A. Vissing-Jorgensen (2018): "The Impact of Pensions and Insurance on Global Yield Curves," Working Paper.

Guerrieri, V. And P. Kondor (2012): "Fund Managers, Career Concerns, and Asset Price Volatility," American Economic Review, 102, 1986-2017.

Haddad, V., A. Moreira, And t. Muir (2021): "When Selling Becomes Viral: Disruptions in Debt Markets in the COVID-19 Crisis and the Fed's Response," Review of Financial Studies, 34, 5309-5351.

Herpfer, C. And G. Maturana (2021): "Who Prices Credit Rating Inflation?" Working Paper.

Iannotta, G., G. Pennacchi, And J. Santos (2019): "Ratings-Based Regulation and Systematic Risk Incentives," The Review of Financial Studies, 32, 1274-1415.

Ivashina, V. And B. Vallée (2020): "Weak Credit Covenants," Working Paper.

Jensen, M. C. And W. H. Meckling (1976): "Theory of the firm: Managerial behavior, agency costs and ownership structure," Journal of Financial economics, 3, 305-360.

John, T. And K. John (1993): "Top-Management Compensation and Capital Structure," Journal of Finance, 48, 949-974.

Koijen, R. S. J. And M. Yogo (2021): "The evolution from life insurance to financial engineering," Geneva Risk and Insurance Review, 46, 89-111.

_ (2022): "The Fragility of Market Risk Insurance," Journal of Finance, 77, 815-862.

Krishnamurthy, A. And T. Muir (2020): "How Credit Cycles across a Financial Crisis," Working Paper.

Krishnamurthy, A. And A. Vissing-Jorgensen (2011): "The Effects of Quantitative Easing on Interest Rates: Channels and Implications for Policy," Brookings Papers on Economic Activity. 
Kubitza, C. (2021): "Investor-Driven Corporate Finance: Evidence from Insurance Markets," Working Paper.

LuCK, S. And T. Zimmermann (2020): "Employment effects of unconventional monetary policy: Evidence from QE," Journal of Financial Economics, 135, 678-703.

Midrigan, V. And D. Xu (2014): "Finance and Misallocation: Evidence from Plant-Level Data," American Economic Review, 104, 422-458.

Morgan Stanley (2018a): "M\&Aking a Leveraged Balance Sheet," Corporate Credit Research North America.

- (2018b): "The Nature of the BBBeast," Corporate Credit Research North America.

NAIC (2015): "Capital Markets Special Report," Special report, National Association of Insurance Commissioners.

RAJAN, R. (2013): "A step in the dark: unconventional monetary policy after the crisis," Andrew Crockett Memorial Lecture.

Rodnyansky, A. And O. Darmouni (2017): "The Effects of Quantitative Easing on Bank Lending Behavior," Review of Financial Studies, 30, 3858-3887.

S\&P Global (2020a): "BBB Bond Downgrades Added USD 88 Billion to the High-Yield Bond Market YTD," Online, accessed 1 February 2021.

- (2020b): "Fed expands primary and secondary facilities to boost fallen angels," Online, accessed 27 September 2021.

Stein, J. (2013): "Overheating in Credit Markets: Origins, Measurement, and Policy Responses," "Restoring Household Financial Stability after the Great Recession: Why Household Balance Sheets Matter" research symposium.

Vayanos, D. And J.-L. Vila (2021): "A Preferred-Habitat Model of the Term Structure of Interest Rates," Econometrica, 89, 77-112.

Whited, T. And J. Zhao (2021): "The Misallocation of Finance," The Journal of Finance, $76,2359-2407$.

Wu, J. And F. XiA (2016): "Measuring the Macroeconomic Impact of Monetary Policy at the Zero Lower Bound," Journal of Money, Credit, and Banking, 48, 253-291. 


\title{
Online Appendix
}

Exorbitant Privilege? Quantitative Easing and the Bond Market Subsidy of Prospective Fallen Angels

\author{
Viral V. Acharya \\ Ryan Banerjee \\ Matteo Crosignani \\ Tim Eisert \\ Renée Spigt
}

June 2022 


\section{Structure}

This online appendix is structured as follows. Appendix A explains the data construction. Appendix B presents our theoretical framework. Appendix C shows some aggregate facts. Appendix D shows that the existence of a bond financing privilege by prospective fallen angels is empirically robust. Appendix E presents a set of results about M\&A activity. Appendix F shows how we calculate the subsidy enjoyed by prospective fallen angels from 2009 to 2019 . Appendix G presents additional figures.

\section{Appendix A Data construction}

Issuer-level analysis We start with the capital information provided by WRDS Capital IQ, which covers over 60,000 public and private companies globally. The data set describes the firms' debt capital structure over the years 2009 to 2019. We drop the observations for which the debt categories ${ }^{22}$ do not add up to 100 per cent and deviate by more than 5 per cent. Moreover, we exclude the observations for which the principal debt amount percentage is missing. ${ }^{23}$

We then combine the CapitalIQ data with the company specific information from Compustat North America, which provides the financial statements of listed American and Canadian firms. We further reduce the sample by dropping firms that are not incorporated in the U.S. or have a SIC-code between 6000-6999. In addition, we exclude the observations that contain missing values for the CapitalIQ debt categories or the Compustat debt items. To merge the debt items of the two providers, we match the total amount of debt outstanding of CapitalIQ to the sum of the current liabilities (DLC) and long-term debt (DLTT) items of Compustat. We drop the observations for which the two values vary by more than 10 per cent to assure a clean matching procedure. Moreover, we drop firms that have a leverage ratio exceeding one.

The issuer CUSIPs allow us to merge the Capital IQ Compustat data set to the rating data from Thomson Reuters, which provides worldwide coverage on ratings from S\&P, Moody's and Fitch. We follow Becker and Milbourn (2011) in transferring the ratings into numerical values to estimate the firms' median ratings. For the rating classification, we refer to Table A.1 in the Appendix. Furthermore, we use the issuer CUSIPS to obtain M\&A deal information from ThomsonOne. Combining all the data sources, we investigate a total of 6,145 firms.

Bond-level analysis The second type of data sets we create are on a bond-level and are used to investigate primary and secondary market pricing. For the primary market analysis,

\footnotetext{
${ }^{22}$ The debt categories consist of commercial paper, revolving credit, subordinated bonds and notes, senior bonds and notes, general/other borrowings, capital leases, and term loans. We also take into account the total trust preferred, unamortized premium, unamortized discount and adjustment items.

${ }^{23}$ The principal debt amount outstanding percentage can deviate from 100 per cent due to potential debt adjustments. The percentage is used to scale the principal debt outstanding to the total amount of debt outstanding.
} 
we use Mergent Fixed Income Securities Database (FISD), a fixed income database that includes issue details of publicly-offered U.S. bonds. This sample consists of 6,460 bond issues and 909 issuers. For the second market pricing, we use TRACE, which is a database that constitutes of real-time secondary market information on transactions in the corporate bond market. This analysis is based on 7,741 outstanding bonds by 1,146 issuers, with bond $b$, firm $j$, year $t$ as unit of observation. For the COVID analysis, we extend our data set to 2020.

Investor-level analysis Our investor-level analysis is based on a data set constructed using the eMAXX Bond Holders data from Refinitiv, matched with the Fed SOMA portfolio data and our issuer-level and bond-level information. The data set is constructed as follows. The data set from eMAXX has security level holdings at a quarterly frequency from 2008Q4. Securities are identified with cusip8 and the holdings amount are denominated in USD. There are two investors' identifiers: firmid (uniquely identifies a managing firm) and fundid (uniquely identifies a sub-account). This data has around 160 million observations corresponding to 4,244 unique firmid and 47,145 fundid. Note that one firmid might have several different fundid (there might be multiple funds per firm) and one fundid might have several different firmid (funds might be co-managed by different firms). We use fundid to identify investors in our analysis. We measure investor-level exposure to QE in quarter $t$ calculating the share of investor total holdings that are held by the Fed (holdings are weighted by the share of amounts outstanding held by the Fed). Having calculated this exposure (and total holdings and total corporate bond holdings for each fund ), we only keep observations corresponding to securities issued by the 6,179 issuers at the intersection of Compustat and CapIQ that have bonds outstanding in the period from June 30, 2009 to December 31, 2019. We identify issuers using cusip6 and gvkey. We end up with around 16 million observations, corresponding to 14,268 investors, 1,701 issuers, and 13,359 securities. At this stage, we match the data set with investor level characteristics from eMAXX Bond Holders and security-level characteristics (amount issued, issued date, maturity, M\&A purpose dummy), bringing our data set to 13.8 million observations, corresponding to 13,577 investors, 1,494 issuers, and 11,231 securities. We then collapse our data set at the issuer-investor-quarter level. Our data runs quarterly from 2009 to 2019 and features 2,750 investors and 1,442 corporate bond issuers. Out of the 2,750 funds, 223 are annuities, 590 are life and health insurance, 934 are property and casualty insurance, and around 800 are mutual funds (the exact number depends on definition of mutual fund). Out of the 1,442 corporate bond issuers, 3 are rated AAA, 24 are rated AA, 137 are rated $\mathrm{A}, 360$ are rated $\mathrm{BBB}, 390$ are rated $\mathrm{BB}$, and 345 are rated $\mathrm{B}$.

Transferring ratings into numerical values Following Becker and Milbourn (2011), we transfer the ratings of S\&P, Moody and Fitch into numerical values using Table A.1. This way we can estimate the median rating for each rated firm in our data set.

Z"-score cutoff points We take median Z"-score values for each rating category from Altman (2020). These medians are measured in 2013 for the main analysis and in 2006 for the pre-GFC sample. 


\begin{tabular}{lcc} 
Moody's & S\&P $/$ Fitch & Numerical value assigned \\
\hline AAA & AAA & 28 \\
Aa & AA & $24,25,26$ \\
A & A & $21,22,23$ \\
Baa & BBB & $18,19,20$ \\
\hline Ba & BB & $15,16,17$ \\
B & B & $12,13,14$ \\
Caa & CCC & $9,10,11$ \\
Ca & CC & 7 \\
C & C & 4 \\
\hline D & D & - \\
\hline
\end{tabular}

Table A.1: Rating classification. This table presents the rating mapping used in this paper, taken from Becker and Milbourn (2011).

\begin{tabular}{lcc} 
Ratings & Z"-score 2006 & Z"-score 2013 \\
\hline AAA & 7.78 & 8.40 \\
AA & 7.60 & 8.22 \\
A & 6.47 & 5.80 \\
BBB & 6.25 & 5.60 \\
\hline BB & 5.05 & 4.81 \\
B & 2.98 & 2.84 \\
CCC & 0.84 & 0.05 \\
\hline
\end{tabular}

Table A.2: Z"-score cutoff points This table presents the Z"-score values below which a firm in a given rating bucket will be classified as vulnerable for each rating category from Altman (2020).

\section{Appendix B Theoretical framework}

In this appendix, we present a simple model to explain how the exorbitant privilege of prospective fallen angels can arise in equilibrium. This model adds a subsidy for debt financing to an environment similar to the one in John and John (1993).

Setup There are two dates, $t=0$ and $t=1$, and universal risk neutrality. A firm with debt $F$ can invest in a safe investment and a risky investment. The safe investment pays off $I$ with probability 1 at $t=1$. The risky investment pays off $H$ with probability $q$ and $L$ with probability $1-q$, where $H>I>L$ and $q \sim U[0,1]$. The debt provides a tax shield (the tax rate is $\tau$ ) and there is limited liability. The timing works as follows: (i) The firm chooses $F$; (ii) The probability $q$ is realized; and (iii) The firm makes its investment decision.

Firm risk The firm invests in the risky project if and only if $q \geq \widetilde{q}$. We refer to $\widetilde{q}$ as the risk of the firm (for illustrative purposes, we will refer to $1-\widetilde{q}$ as firm risks when presenting the results). Depending on the level of firm debt $F$, there are three cases:

1. A "low debt case" with $F \leq L$. Firms choose the first-best risk $\widetilde{q}=\frac{I-L}{H-L}$. There is no agency cost of debt.

2. A "moderate debt case" with $F \in(L, I)$. Firms choose the second-best risk $\widetilde{q}=\frac{I-F}{H-F}$, where $\frac{d \widetilde{q}}{d F}=-\frac{H-I}{(H-F)^{2}}<0$, namely firms take more risk (lower $\widetilde{q}$ ) as their debt increases. 
3. A "high debt case" with $F \geq I$. Firms choose the highest level of risk $(\widetilde{q}=0)$ as they always take the risky project.

Fairly priced debt The firm chooses the level of debt $F$ that maximizes firm value $V(F)$. The debt is fairly priced. There are three states of the world that depend on the realization of the probability $q$.

1. The firm chooses to undertake the riskless project. This state of the world has an unconditional probability of $\widetilde{q}$.

2. The firm chooses to undertake the risky project and the risky project fails. This state of the world has an unconditional probability of $(1-\widetilde{q})^{2}$.

3. The firm might chooses to undertake the risky project and the risky project succeeds. This state of the world has an unconditional probability of $\left(1-\widetilde{q}^{2}\right)$.

Hence, firms solve:

$$
\begin{aligned}
\max _{F} V(F) & \quad \text { where } \\
V(F) & =\frac{1}{2}\left(1-\widetilde{q}^{2}\right)((1-\tau) H+\tau \min \{H, F\}) \\
& +\widetilde{q}((1-\tau) I+\tau \min \{I, F\}) \\
& +\frac{1}{2}(1-\widetilde{q})^{2}((1-\tau) L+\tau \min \{L, F\})
\end{aligned}
$$

Firms trade-off the tax benefit of debt with the agency cost of debt. Given the tax shield, firms never choose a debt $F<L$. Hence, firms can either have "moderate debt" or "high debt." In most of our analysis, we focus on the former as the latter is always characterized by maximum risk-taking $(\widetilde{q}=0)$.

Non-fairly priced debt We compare the economy presented above with an economy where debt is not fairly priced. More specifically, the value of debt now includes a subsidy $\alpha$. Firms now solve:

$$
\begin{array}{ll}
\max _{F} & \widehat{V}(F) \quad \text { where } \\
& \widehat{V}(F)=V(F)+\alpha F
\end{array}
$$

The subsidy induces firms to take on more debt and thus more risk (lower $\widetilde{q}$ ). This subsidy can be rationalized by a high demand for debt.

Mapping the model to data The tax rate $\tau$, the primitive driving the firm debt choice and thus its risk profile, is firm quality. We map intervals in $\tau$ to credit ratings. The cost of debt $S=F / D(F)$ is the bond yield. Firm risk $1-\widetilde{q}$ is the risk-taking behavior of firms, for example through risky M\&A. The subsidy parameter $\alpha$ is the strength of the demand for bonds. We increase the demand for bonds within each rating bucket as $\tau$ increases, capturing 
the idea that investors demand more bonds of riskier firms within a rating bucket. This behavior can be explained by rating-based regulation or implicit and explicit limits that investment managers face in their asset allocation across ratings. To the extent that riskier issuers offer higher bond yields, the higher demand for bonds issuer by riskier firms might also capture the so-called "reach-for-yield" behavior.

Applications We now show two applications to interpret our empirical findings through the lenses of the framework just presented. Figure B.1 shows firm risk choice and bond yields as a function of firm quality. The x-axes feature increasing tax rates $\tau$, grouped in rating categories. We compare three cases: an economy with normal demand for IG bonds (blue solid line), an economy with moderate demand for IG bonds (red dashed line), and an economy with high demand for IG bonds (black dotted line). As discussed above, the subsidy increases as firm quality deteriorates within each rating bucket. Within each rating bucket, the subsidy induces higher risk-taking, and more so as we approach the BBB-rated market. The subsidy both flattens and introduces a convexity in bond yields.

Figure B.2 shows average bond yields and firm risk-taking within each rating bucket for the three cases discussed above: normal demand for IG bonds, moderate demand for IG bonds, and high demand for IG bonds. 


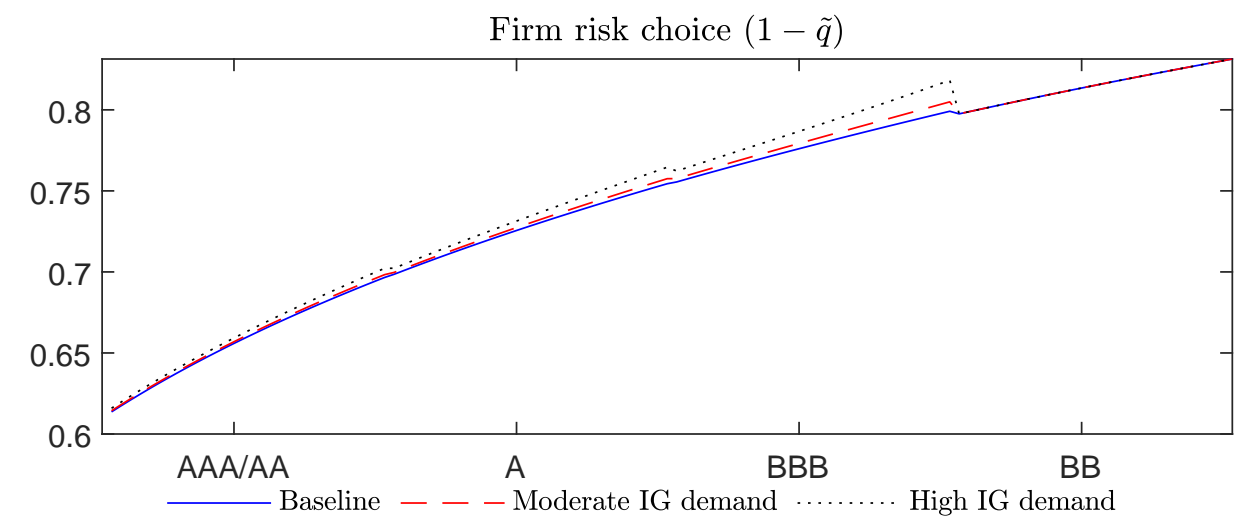

Bond yields $(S)$

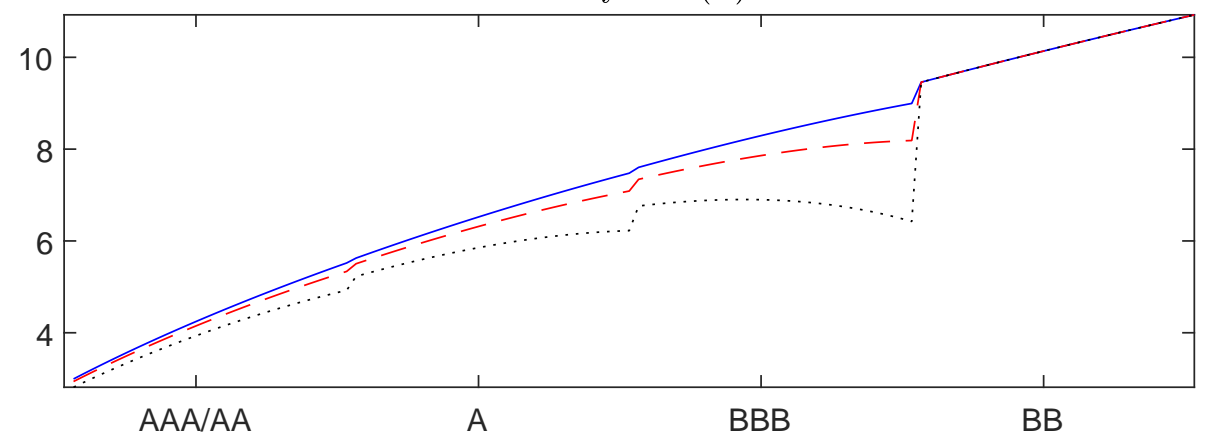

Figure B.1: Firm risk-taking and bond yields. This figure shows firm risk choice (top panel) and firm bond yields (bottom panel) as a function of firm quality. The x-axes show progressively higher tax rates, grouped in rating categories. The blue line corresponds to the baseline economy. The red dashed line corresponds to an economy with moderate demand for risk. The black dotted line corresponds to an economy with high demand for risk. Demand for risk is modeled through an increase in alpha within each rating group in the investment-grade market. The increase is more pronounced as we approach the BBB market from the AAA/AA market. 

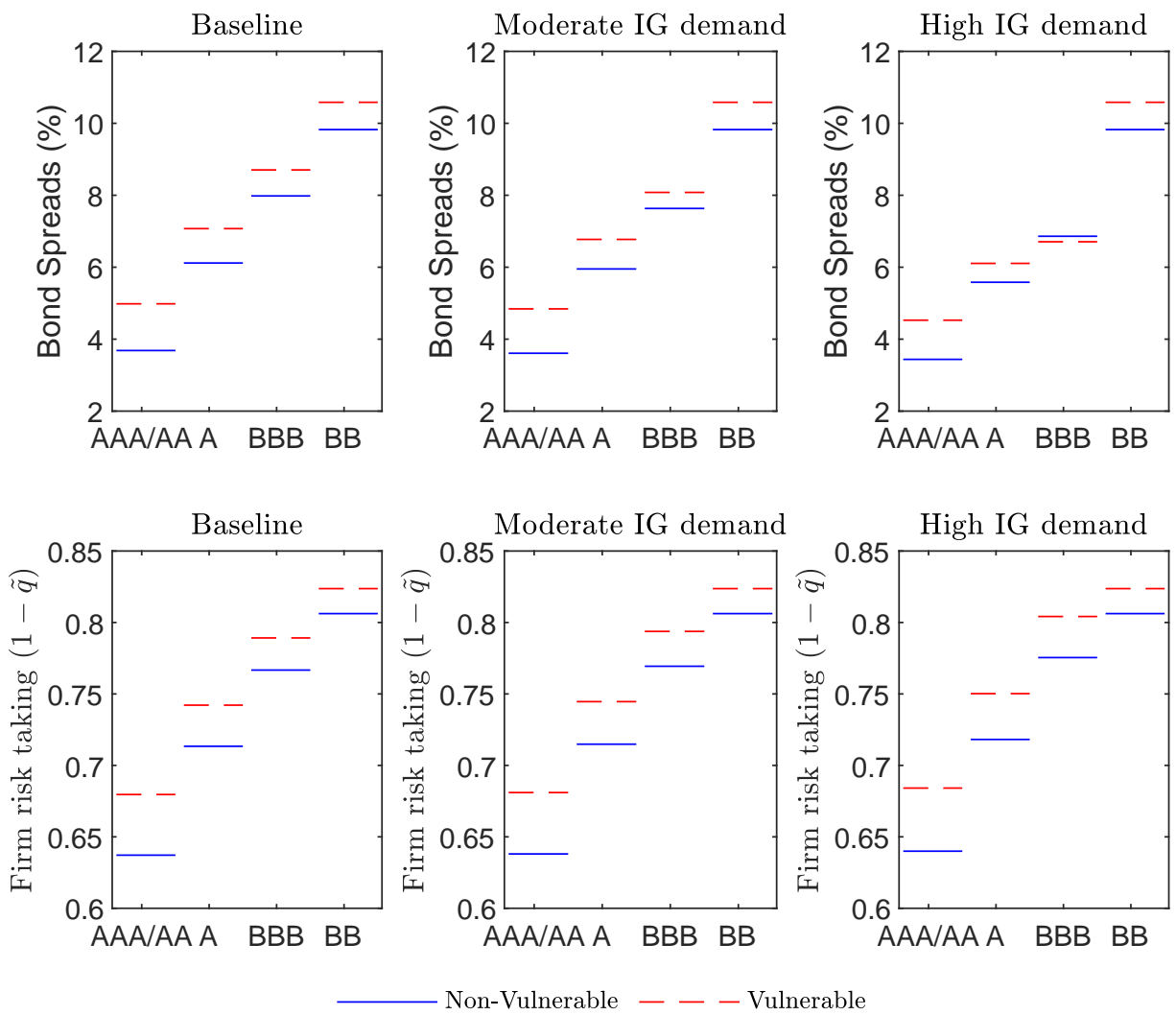

Figure B.2: Firm risk-taking and bond yields. This figure shows bond spreads (top panel) and firm risk choice (bottom panel) as a function of firm quality. The x-axes show progressively higher tax rates, grouped in rating categories. The blue lines show averages within a rating group for non-downgrade vulnerable issuers. The red lines show averages within a rating group for downgrade vulnerable issuers. The two left panels correspond to the baseline economy. The two middle panel correspond to an economy with moderate demand for risk. The two right panels correspond to an economy with high demand for risk. Demand for risk is modeled through an increase in $\alpha$ within each rating group in the investment-grade market. The increase is more pronounced as we approach the $\mathrm{BBB}$ market from the AAA/AA market. 


\section{Appendix C Aggregate facts}
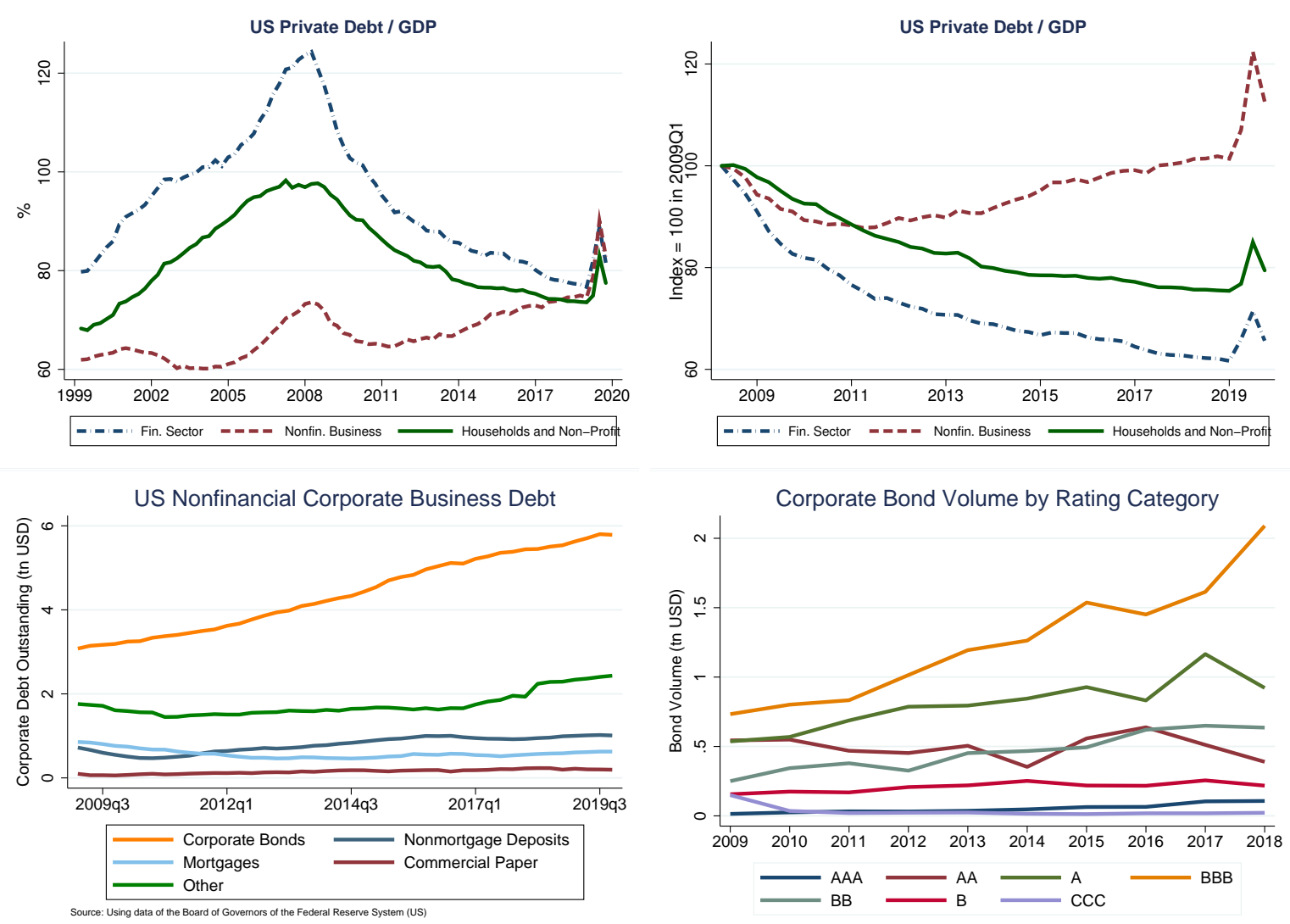

Figure C.1: The growth of the U.S. non-financial corporate debt. This figure shows the growth of the U.S. non-financial corporate debt and, in particular, of the U.S. corporate bond market. The top left panel shows the evolution of the financial sector debt, non-financial sector debt, and household debt, normalized by GDP. The sources are series dodfs, tbsdodns and cmdebt from FRED. The top right panel is an index where these series are normalized to 100 in 2009Q1. The bottom left panel shows the evolution of corporate bonds, mortgages, non-mortgage deposits (includes loans from banks, credit unions, and savings and loans associations), commercial paper and other (loans from non-bank institutions, excluding mortgages, and industrial revenue bonds). The sources are series cblbsnncb, mlbsnncb, ncbilia027n, cplbsnncb and olalbsnncb from FRED. The bottom right panel shows the evolution of the stock outstanding of corporate bonds, grouped by rating category. Sources: Capital IQ and Thomson Reuters. 


\section{Appendix D The exorbitant privilege}

\section{D.1 Validating the downgrade-vulnerability measure}

In this section, we first show how the balance sheet characteristics of vulnerable rated firms differ from those of non-vulnerable rated firms. Thereafter, we show how a firm's downgrade probability, balance sheet characteristics and firm performance change after a firm is classified as vulnerable.

In Table D.1, we present the descriptive statistics for the rated firms in our sample, separated for firms that are vulnerable and firms that are not vulnerable. The sample means highlight that vulnerable firms are larger and riskier along all dimensions. In particular, vulnerable firms have higher leverage, lower profitability, lower net worth, and a lower interest coverage ratio. Their sales growth, employment growth, and investment ratio are also significantly lower than those of non-vulnerable firms. The last column shows a test for the difference in means.

Next, we show that vulnerable firms are more likely to be downgraded and to be assigned a negative credit watch or outlook status relative to non-vulnerable firms. To this end, we estimate the following specification:

$$
Y_{i h t+1}=\beta_{1} \text { Vulnerable }_{i h t}+\beta_{2} X_{i h t}+\mu_{h t}+\epsilon_{i h t+1},
$$

where $i$ is a firm, $h$ an industry, and $t$ a year. Our dependent variable $Y$ is a dummy equal to one in the case of a negative watch event in $t$ or $t+1$, or a downgrade event in $t+1$. To qualify as downgrade event, a firm must be downgraded by at least one rating category in year $t+1$, i.e. a firm that has a rating of $\mathrm{A}+, \mathrm{A}$, or $\mathrm{A}$ - is downgraded to at least $\mathrm{BBB}+$. Vulnerable is a dummy equal to one if a firm is vulnerable in period $t$ and $\mu_{h t}$ are industry-year fixed effects. $X_{i h t}$ is a vector of controls, namely the logarithm of total assets, leverage, and the interest coverage ratio.

Table D.2 presents the estimation results. The first two columns show that a vulnerable company in year $t$ is more likely to have a negative watch event in year $t$ or $t+1$. Similarly,

\begin{tabular}{lccc} 
& Downgrade-vulnerable & Non-downgrade-vulnerable & Difference \\
\hline Total Assets & 24,114 & 10,988 & $13,126^{* * *}$ \\
Leverage & 0.403 & 0.354 & $0.049^{* * *}$ \\
EBITDA/Assets & 0.104 & 0.132 & $-0.028^{* * *}$ \\
Interest Coverage & 7.747 & 13.114 & $-5.367^{* * *}$ \\
Sales Growth & 0.038 & 0.056 & $-0.017^{* * *}$ \\
CAPX & 0.188 & 0.225 & $-0.037^{* * *}$ \\
Employment Growth & 0.008 & 0.036 & $-0.027^{* * *}$ \\
Net Worth & 0.183 & 0.248 & $-0.066^{* * *}$ \\
\hline
\end{tabular}

Table D.1: Descriptive statistics: downgrade-vulnerable and non-downgrade-vulnerable firms. This table presents descriptive statistics for rated firms in our sample, separated into vulnerable and nonvulnerable firms. Total Assets is in millions, Leverage is total debt over total assets, Interest Coverage is EBITDA over interest expenses, Sales Growth is the growth rate in sales, CAPX is capex over PPE, Employment Growth is the growth rate in employment, Net Worth is the difference between common equity and cash divided by total assets. 
the last two columns show that a vulnerable firm has a higher probability to be downgraded by at least one rating category in the next year.

\begin{tabular}{|c|c|c|c|c|}
\hline & Negative Watch & Negative Watch & Downgrade & Downgrade \\
\hline \multirow[t]{2}{*}{ Vulnerable } & $0.078^{* * *}$ & $0.043^{* *}$ & $0.021^{* * *}$ & $0.018^{* * *}$ \\
\hline & $(0.018)$ & $(0.018)$ & $(0.005)$ & $(0.005)$ \\
\hline \multirow[t]{2}{*}{ Size } & & $0.017^{* *}$ & & $0.003^{*}$ \\
\hline & & $(0.007)$ & & $(0.002)$ \\
\hline \multirow[t]{2}{*}{ Leverage } & & $0.131^{* *}$ & & 0.016 \\
\hline & & $(0.055)$ & & $(0.015)$ \\
\hline \multirow[t]{2}{*}{ IC Ratio } & & $-0.010 * * *$ & & $-0.000^{* *}$ \\
\hline & & $(0.001)$ & & $(0.000)$ \\
\hline Industry-Year FE & $\checkmark$ & $\checkmark$ & $\checkmark$ & $\checkmark$ \\
\hline Observations & 9,056 & 8,973 & 9,431 & 9,341 \\
\hline R-squared & 0.118 & 0.150 & 0.094 & 0.097 \\
\hline
\end{tabular}

Table D.2: Credit rating actions after being classified as vulnerable. This table presents the estimation results from Specification (D1) for our sample of rated firms. The dependent variable Negative Watch is a dummy variable equal to one if a firm is placed on negative credit watch or outlook in year $t$ or $t+1$. The dependent variable Downgrade is a dummy variable equal to one if a firm is downgraded by at least one rating category in year $t+1$, i.e., a firm that has a rating of $\mathrm{A}+, \mathrm{A}$, or $\mathrm{A}$ - is downgraded to at least $\mathrm{BBB}+$. Vulnerable is a dummy equal to one if a firm is vulnerable in period $t$. Firm level control variables are size (log of total assets), leverage and IC ratio. Standard errors clustered at the firm level in parentheses. $* * * \mathrm{p}<0.01,{ }^{* *} \mathrm{p}<0.05,{ }^{*} \mathrm{p}<0.1$.

Finally, we examine how the balance sheet characteristics of vulnerable firms change after the obtaining the vulnerability status. Following Banerjee and Hofmann (2020), we create a local linear projection specification, based on a sequence of regression models where the dependent variable is shifted several steps forward and backward in time, relative to a reference point. Our reference point is the date at which a firm is classified as vulnerable for the first time. Specifically, we estimate the following specification:

$$
Y_{i h t+q}=\beta_{q} \text { Enter Vulnerable } e_{i h t}+\gamma_{q} \text { Vulnerable }_{i h t}+\eta_{q} X_{i h t+q}+\mu_{h t+q}+\epsilon_{i h t+q},
$$

where $i$ is a firm, $h$ an industry, $t$ a year, and $q \in \mathcal{Q}$, where $\mathcal{Q}=\{-3,-2,-1,0,1,2,3\}$. The dependent variable $Y$ is asset growth, employment growth, sales growth, and capital expenditures in period $t+q$. EnterVulnerable is a dummy equal to one if a firm becomes vulnerable for the first time in period $t$. Vulnerable is a dummy equal to one if a firm is vulnerable in period $t$, but did not become vulnerable in period $t$ for the first time, i.e., it has been classified as vulnerable before. This specification ensures we compare firms becoming vulnerable for the first time only to non-vulnerable firms. $X_{i h t+q}$ is the logarithm of total assets and $\mu_{h t+q}$ are industry-year fixed effects.

The coefficient of interest $\beta_{q}$ measures a vulnerable firm's development, in the three years before and after the firm is classified as vulnerable, of sales growth, investments, asset growth, and employment growth. A positive (negative) coefficient implies that a vulnerable firm has a higher (lower) value of the respective dependent variable compared to a non-vulnerable firm. Figure D.1 shows the estimated $\beta_{q}$ coefficients, documenting that firm performance 
deteriorates once it becomes vulnerable. Its sales growth and investment decline significantly, a dynamic also reflected in the drop in firm size and employment growth.
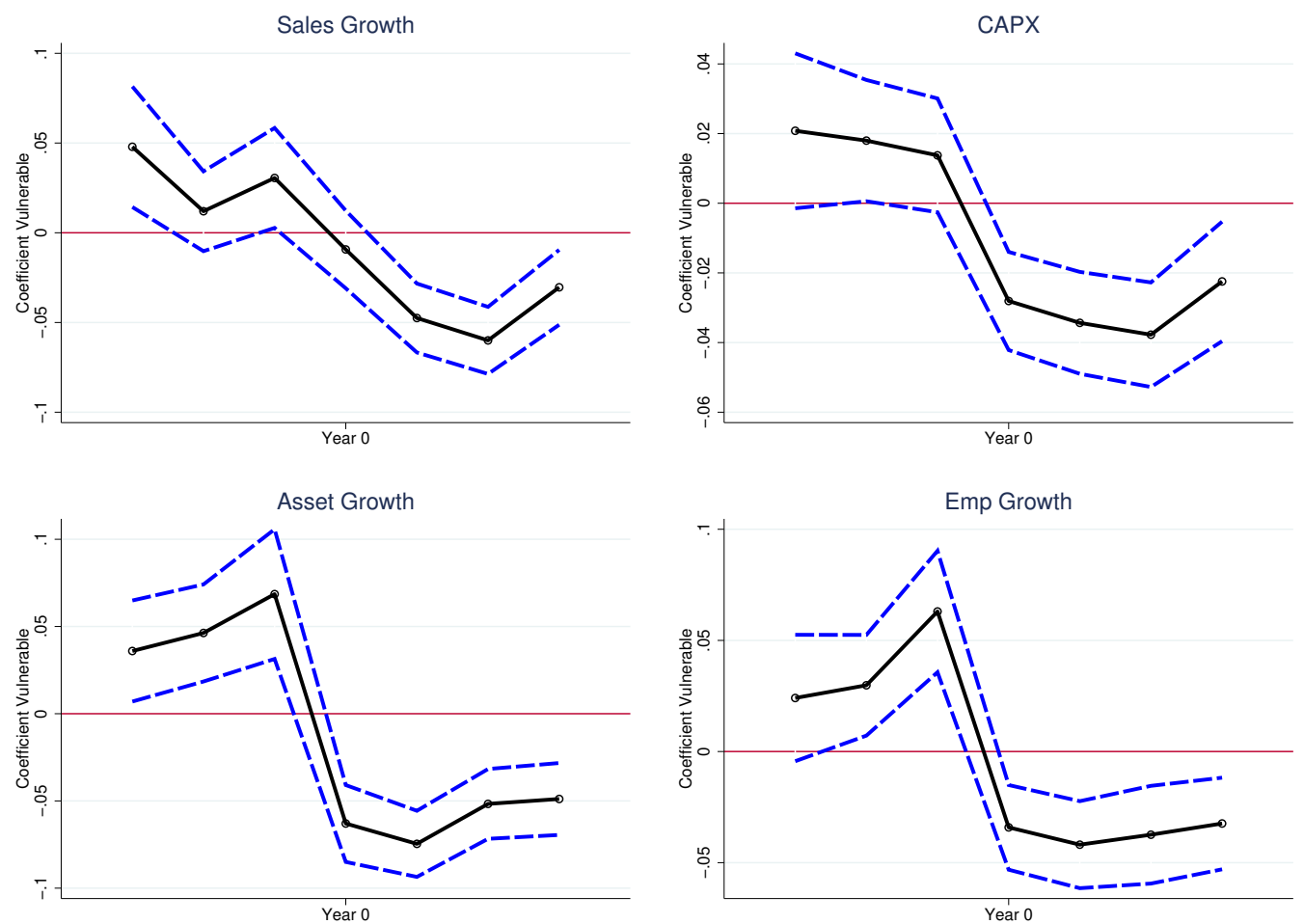

Figure D.1: Firm performance after being classified as downgrade-vulnerable. This figure shows the evolution of the estimated coefficient $\beta_{q}$ from Specification (D1) three years before and after a firm becomes downgrade-vulnerable. Year zero corresponds to the first year a firm is classified as downgrade-vulnerable. The $95 \%$ confidence interval is reported, with standard errors clustered at the firm level.

\section{D.2 Descriptive statistics of bonds by vulnerability}

Panel A of Table D.3 shows that the characteristics of bonds issued by downgrade-vulnerable firms are similar to those issued by non-downgrade-vulnerable firms. The remaining maturities are similar, with a median remaining maturity of 6.7 and 6.6 years respectively. The offering amounts are also similar as is the likelihood of bonds being classified as senior and also whether the bond is callable. On average, secondary market spreads on bonds issued by downgrade-vulnerable firms are lower than spreads of non-downgrade-vulnerable firms. Panel $\mathrm{B}$, however, shows that this is driven by a composition effect across the sample. Within each rating category secondary market spreads of bonds issued by downgrade-vulnerable firms are higher than those of their non-downgrade-vulnerable peers across the distribution. The one exception is the BBB segment where bond spreads are lower than their non-vulnerable peers. 
Panel A: Bond-level descriptive statistics

\begin{tabular}{llrrrrr}
\hline Variable & Vulnerable & Mean & StDev & p25 & p50 & p75 \\
\hline Remaining maturity & No & 9.7 & 8.5 & 3.9 & 6.7 & 9.9 \\
Remaining maturity & Yes & 10.3 & 9.0 & 3.8 & 6.8 & 15.1 \\
$\log$ (offering amount) & No & 13.2 & 0.6 & 12.8 & 13.1 & 13.5 \\
$\log$ (offering amount) & Yes & 13.4 & 0.7 & 12.9 & 13.3 & 13.8 \\
Senior bond & No & 0.7 & 0.4 & 0.0 & 1.0 & 1.0 \\
Senior bond & Yes & 0.7 & 0.4 & 0.0 & 1.0 & 1.0 \\
Callable bond & No & 0.9 & 0.3 & 1.0 & 1.0 & 1.0 \\
Callable bond & Yes & 0.9 & 0.3 & 1.0 & 1.0 & 1.0 \\
Spread & No & 136.0 & 150.8 & 59.4 & 97.5 & 161.4 \\
Spread & Yes & 132.1 & 163.6 & 58.3 & 95.4 & 151.1 \\
\hline
\end{tabular}

Panel B: Bond spreads by rating

\begin{tabular}{llrrrrr}
\hline Rating & Vulnerable & Mean & $\mathrm{p} 25$ & $\mathrm{p} 50$ & $\mathrm{p} 75$ & $\mathrm{Std}$ Dev \\
\hline AAA-AA & No & 40.5 & 16.9 & 31.3 & 53.4 & 32.4 \\
AAA-AA & Yes & 42.1 & 21.8 & 36.4 & 55.9 & 26.8 \\
Difference & & 1.6 & 4.9 & 5.1 & 2.5 & \\
A & No & 60.0 & 35.3 & 52.9 & 73.8 & 34.7 \\
A & Yes & 65.5 & 41.2 & 58.6 & 82.1 & 33.7 \\
Difference & & 5.4 & 5.9 & 5.6 & 8.4 & \\
BBB & No & 110.1 & 72.3 & 99.7 & 134.4 & 54.0 \\
BBB & Yes & 106.7 & 67.7 & 93.2 & 129.9 & 56.8 \\
Difference & & -3.4 & -4.6 & -6.5 & -4.5 & \\
BB & No & 223.1 & 167.8 & 216.4 & 270.1 & 93.5 \\
BB & Yes & 253.1 & 179.3 & 239.3 & 308.0 & 115.6 \\
Difference & & 30.0 & 11.4 & 22.9 & 37.9 & \\
B & No & 358.8 & 246.5 & 327.7 & 431.0 & 175.9 \\
B & Yes & 500.2 & 326.1 & 429.6 & 580.0 & 325.7 \\
Difference & & 141.4 & 79.6 & 101.9 & 149.0 & \\
CCC & No & 1104.4 & 557.9 & 769.7 & 1451.0 & 793.7 \\
CCC & Yes & 1277.1 & 699.1 & 975.6 & 1502.3 & 880.7 \\
Difference & & 172.7 & 141.2 & 205.8 & 51.3 & \\
\hline
\end{tabular}

Table D.3: Bond-level summary statistics. This table reports bond-level summary statistics. Panel A shows descriptive statistics for all bonds in our sample. Panel B shows secondary market spreads by issuers' downgrade-vulnerability.

\section{D.3 Risk materialization with COVID-19}

In this section, we provide parametric evidence that BBB firms with more inflated credit ratings experienced a sharper increase in spreads in 2020. Finally, we show non-parametrically 
that the vulnerable BBB-rated firms that engaged in M\&A activity in the past had more (severe) downgrades than vulnerable BBB-rated firms that did not.

In a next step we provide more formal evidence for that riskier BBB firms experienced a sharper increase in bond spreads in March 2020. More precisely, we estimate the following specification in which we relate the degree of ratings inflation at the start of 2020 to the change in a firm's bond spreads:

$$
\Delta \text { Spread }_{i j h}=\beta_{1} \text { Rating Inflation }_{j h}+\gamma_{j h}+\phi_{h}+\epsilon_{i j h}
$$

$\Delta$ Spread $_{i j h}$ is the change in secondary market spread between January 2020 and March 2020 of bond $i$ of firm $j$ in industry $h$, Rating Inflation $_{j h}$ is the difference between the issuer rating at the start of 2020 and the implied rating based on Altman Z"-score, and $\phi_{h}$ are industry fixed effects.

Table D.4 presents our results. In Column (1) we show that a greater difference between a vulnerable BBB rated firm's assigned rating and its implied rating leads to a greater change in spreads when the pandemic started. In particular, a one notch inflated issuer rating is on average associated with a 16 basis points increase in bond spreads for vulnerable BBB rated firms. In contrast the second columns shows that no such relationship exists for the other vulnerable investment grade rated firms.

\begin{tabular}{lcc} 
& $\Delta$ Spread & $\Delta$ Spread \\
\hline Rating Inflation & $15.804^{* * *}$ & -1.178 \\
& $(3.529)$ & $(5.822)$ \\
\hline Sample & Vuln. BBB & Vuln. A-AAA \\
\hline Industry FE & $\checkmark$ & $\checkmark$ \\
Firm Controls & $\checkmark$ & $\checkmark$ \\
\hline Observations & 751 & 391 \\
R-squared & 0.503 & 0.552 \\
\hline
\end{tabular}

Table D.4: Change in spreads of rating-inflated firms during COVID-19. This table presents estimation results from the bond-level regression (D2). The dependent variable is $\Delta$ Spread, which is defined as the change in secondary market spread between January 2020 and March 2020 of a single bond. The independent variable is RatingInflation and is defined as the issuer rating at the start of 2020 minus the implied rating based on Altman Z"-score. We add a firm's total assets as firm control, and a set of industry fixed effects. In the first column the sub-sample consists of BBB rated firms and in the second column of non-BBB investment grade rated firms. Standard errors are clustered at the firm $j$ level and reported in parentheses. ${ }^{* * *} \mathrm{p}<0.01,{ }^{* *} \mathrm{p}<0.05,{ }^{*} \mathrm{p}<0.1$. 


\section{D.4 Additional robustness tests of the exorbitant privilege}

In this section, we provide additional tests examining the exorbitant privilege of vulnerable BBB firms. We first examine the sensitivity of our baseline results in Table 1 to the use of bond instead of firm-level ratings and additional controls for bond liquidity.

Table D.5 shows that the vulnerable BBB exorbitant privilege remains if we use bond-level ratings to define vulnerability. The point estimates are almost unchanged compared with our baseline results. The results with bond-level ratings also confirm the finding of higher spreads in the 2013-16 period both in secondary and primary markets.

The second set of tests examine whether systematic differences in the liquidity of vulnerable and non-vulnerable bonds may drive our results. In addition to controlling for bid-ask spreads at the rating level, the first two columns of Table D.6 additionally control for the number of times a bond is traded in a month. Similar to bid-ask spreads we allow the coefficients of the number of trades to vary by ratings category. The first column shows bonds which tend to trade more frequently have higher spreads. Nevertheless, the point estimates of the prospective fallen angel subsidy remains almost unchanged. In columns (3) to (6) we examine if the age of the bond affects our results. Columns (3) and (5) confirm the fallen angel privilege in both on-the-run bonds that were issued over the past twelve months as well as in older bonds, with both regressions having almost identical estimates of around 11 basis points. Columns (4) and (6) confirm that spreads were higher in the 2013-16 period, with slightly higher point estimates in the on-the-run sample. 


\begin{tabular}{|c|c|c|c|c|}
\hline & Spread & Spread & Offer Spread & Offer Spread \\
\hline A & $\begin{array}{l}18.069 \\
(12) 03)\end{array}$ & $26.892^{* * *}$ & $28.153^{*}$ & $\begin{array}{l}22.757 \\
(19417)\end{array}$ \\
\hline BBB & $\begin{array}{c}69.378^{* * *} \\
(12.875)\end{array}$ & $\begin{array}{c}78.467^{* * *} \\
(9.086)\end{array}$ & $\begin{array}{c}88.911^{* * *} \\
(14.233)\end{array}$ & $\begin{array}{c}87.631^{* * *} \\
(16.806)\end{array}$ \\
\hline $\mathrm{BB}$ & $\begin{array}{c}170.350^{* * * *} \\
(14.117)\end{array}$ & $\begin{array}{c}170.273^{* * *} \\
(14.204)\end{array}$ & $\begin{array}{c}191.808^{* * * *} \\
(15.421)\end{array}$ & $\begin{array}{c}171.639^{* * *} \\
(20.990)\end{array}$ \\
\hline B & $\begin{array}{c}269.201^{* * *} \\
(17.462)\end{array}$ & $\begin{array}{c}277.771^{* * *} \\
(20.429)\end{array}$ & $\begin{array}{c}254.082^{* * *} \\
(16.062)\end{array}$ & $\begin{array}{c}255.729^{* * *} \\
(26.260)\end{array}$ \\
\hline $\mathrm{CCC}$ & $\begin{array}{c}513.016^{* * *} \\
(48.641)\end{array}$ & $\begin{array}{c}510.402^{\text {**** }} \\
(85.702)\end{array}$ & $\begin{array}{c}310.965^{* * *} \\
(24.983)\end{array}$ & $\begin{array}{c}293.466^{* * *} \\
(42.128)\end{array}$ \\
\hline Vulnerable $\times$ AAA-AA & $\begin{array}{c}-2.882 \\
(11.601)\end{array}$ & $\begin{array}{c}9.253 \\
(8.397)\end{array}$ & $\begin{array}{c}-0.389 \\
(17.815)\end{array}$ & $\begin{array}{l}-12.441 \\
(22.726)\end{array}$ \\
\hline Vulnerable $\times \mathrm{A}$ & $\begin{array}{c}1.143 \\
(4.718)\end{array}$ & $\begin{array}{l}-0.451 \\
(7.356)\end{array}$ & $\begin{array}{l}-0.861 \\
(5.910)\end{array}$ & $\begin{array}{l}-10.215 \\
(12.099)\end{array}$ \\
\hline Vulnerable $\times$ BBB & $\begin{array}{c}-9.273^{* * *} \\
(3.367)\end{array}$ & $\begin{array}{c}-15.229^{* * *} \\
(4.970)\end{array}$ & $\begin{array}{c}-12.604^{* *} \\
(4.924)\end{array}$ & $\begin{array}{c}-26.295^{* * *} \\
(7.547)\end{array}$ \\
\hline Vulnerable $\times$ BB & $\begin{array}{l}15.636^{*} \\
(8.455)\end{array}$ & $\begin{array}{c}34.854^{* *} \\
(14.388)\end{array}$ & $\begin{array}{c}9.886 \\
(9.419)\end{array}$ & $\begin{array}{c}14.347 \\
(17.007)\end{array}$ \\
\hline Vulnerable $\times \mathrm{B}$ & $\begin{array}{c}73.552^{* * *} \\
(24.499)\end{array}$ & $\begin{array}{c}90.564^{* *} \\
(35.794)\end{array}$ & $\begin{array}{c}54.012^{* * *} \\
(12.709)\end{array}$ & $\begin{array}{c}55.764^{* * * *} \\
(16.988)\end{array}$ \\
\hline vulnerable $\times \mathrm{CCC}$ & $\begin{array}{c}319.958^{* *} \\
(127.525)\end{array}$ & $\begin{array}{c}447.016^{* * *} \\
(157.206)\end{array}$ & $\begin{array}{c}49.794 \\
(30.458)\end{array}$ & $\begin{array}{c}40.469 \\
(52.759)\end{array}$ \\
\hline Industry-Year-Month FE & $\checkmark$ & $\checkmark$ & $\checkmark$ & $\checkmark$ \\
\hline Bond-level controls & $\checkmark$ & $\checkmark$ & $\checkmark$ & $\checkmark$ \\
\hline Sample & 2010-19 & 2013-16 & 2010-19 & 2013-16 \\
\hline Observations & 217,106 & 91,431 & 4,493 & 1,902 \\
\hline R-squared & 0.639 & 0.630 & 0.822 & 0.787 \\
\hline
\end{tabular}

Table D.5: Baseline results with bond-level ratings. This table shows the estimation results of specification (2), where bond-level ratings are used instead of issuer-level ratings. The dependent variable in each column is the secondary market bond spreads. Bond spreads are measured in basis points. Vulnerable is a dummy equal to one if at the rating bucket of the bond, the firm's Altman-Z score is below that of the cut-off for the rating bucket below. Additional bond-level controls include residual maturity, amount outstanding and bid-ask spreads, coefficients on the latter are allowed to vary by rating. The specification also includes dummy variables for callable bonds, bonds with a price price above par but below a price of 105 and the interaction between the two variable to account for changes in credit quality affecting spreads on callable bonds. These control variables are included in the estimation but not reported for brevity. These specifications include industry-year-month fixed effects (2-digit SIC). Standard errors are clustered at the firm and year-month level. ${ }^{* * *} \mathrm{p}<0.01,{ }^{* *} \mathrm{p}<0.05,{ }^{*} \mathrm{p}<0.1$. 


\begin{tabular}{|c|c|c|c|c|c|c|}
\hline & Spread $_{i t}$ & Spread $_{i t}$ & Spread $_{i t}$ & Spread $_{i t}$ & Spread $_{i t}$ & Spread $_{i t}$ \\
\hline A & $\begin{array}{c}29.242^{* * *} \\
(7.069)\end{array}$ & $\begin{array}{c}29.069^{* * *} \\
(8.010)\end{array}$ & $\begin{array}{c}21.395^{* * *} \\
(5.789)\end{array}$ & $\begin{array}{c}29.302^{* * *} \\
(4.682)\end{array}$ & $\begin{array}{c}27.681^{* * *} \\
(8.420)\end{array}$ & $\begin{array}{c}28.767^{* * *} \\
(9.464)\end{array}$ \\
\hline BBB & $\begin{array}{c}77.156^{* * *} \\
(7.228)\end{array}$ & $\begin{array}{c}74.784^{* * *} \\
(8.216)\end{array}$ & $\begin{array}{c}66.478^{* * *} \\
(6.046)\end{array}$ & $\begin{array}{c}73.602^{* * *} \\
(5.800)\end{array}$ & $\begin{array}{c}80.202^{* * * *} \\
(8.754)\end{array}$ & $\begin{array}{c}80.073^{* * *} \\
(9.982)\end{array}$ \\
\hline $\mathrm{BB}$ & $\begin{array}{c}177.345^{* * *} \\
(8.751)\end{array}$ & $\begin{array}{c}169.624^{* * *} \\
(11.138)\end{array}$ & $\begin{array}{c}180.852^{* * *} \\
(8.354)\end{array}$ & $\begin{array}{c}192.978^{* * * *} \\
(10.578)\end{array}$ & $\begin{array}{c}183.090^{* * *} \\
(11.220)\end{array}$ & $\begin{array}{c}177.533^{* * *} \\
(15.293)\end{array}$ \\
\hline B & $\begin{array}{c}301.157^{* * * *} \\
(13.080)\end{array}$ & $\begin{array}{c}299.086^{* * *} \\
(21.378)\end{array}$ & $\begin{array}{c}290.967^{* * * *} \\
(13.407)\end{array}$ & $\begin{array}{c}284.286^{* * * *} \\
(22.557)\end{array}$ & $\begin{array}{c}322.081^{* * *} \\
(17.305)\end{array}$ & $\begin{array}{c}332.645^{* * *} \\
(29.418)\end{array}$ \\
\hline $\mathrm{CCC}$ & $\begin{array}{c}965.367^{* * *} \\
(108.813)\end{array}$ & $\begin{array}{c}1,204.623^{* * *} \\
(182.198)\end{array}$ & $\begin{array}{c}722.061^{* * *} \\
(101.199)\end{array}$ & $\begin{array}{c}820.932^{* * *} \\
(151.244)\end{array}$ & $\begin{array}{c}983.977^{* * *} \\
(123.193)\end{array}$ & $\begin{array}{c}1,102.156^{* * *} \\
(217.426)\end{array}$ \\
\hline Vulnerable $\times \mathrm{A}$ & $\begin{array}{c}0.049 \\
(4.618)\end{array}$ & $\begin{array}{l}-5.771 \\
(7.558)\end{array}$ & $\begin{array}{l}-3.044 \\
(5.349)\end{array}$ & $\begin{array}{l}-13.153 \\
(9.085)\end{array}$ & $\begin{array}{l}2.118 \\
(5.019)\end{array}$ & $\begin{array}{l}-1.984 \\
(8.664)\end{array}$ \\
\hline Vulnerable $\times$ BBB & $\begin{array}{c}-10.644^{* * *} \\
(3.294)\end{array}$ & $\begin{array}{c}-17.789^{* * *} \\
(5.183)\end{array}$ & $\begin{array}{c}-11.049^{* *} \\
(4.367)\end{array}$ & $\begin{array}{c}-23.131^{* * *} \\
(6.802)\end{array}$ & $\begin{array}{c}-11.830^{* * *} \\
(3.604)\end{array}$ & $\begin{array}{c}-19.293^{* * *} \\
(6.034)\end{array}$ \\
\hline Vulnerable $\times$ BB & $\begin{array}{l}12.280^{*} \\
(7.454)\end{array}$ & $\begin{array}{c}12.398 \\
(11.578)\end{array}$ & $\begin{array}{c}18.967^{* *} \\
(8.490)\end{array}$ & $\begin{array}{c}15.879 \\
(13.485)\end{array}$ & $\begin{array}{l}12.442 \\
(8.207)\end{array}$ & $\begin{array}{c}11.922 \\
(13.030)\end{array}$ \\
\hline Vulnerable $\times \mathrm{B}$ & $\begin{array}{c}70.596^{* * *} \\
(21.153)\end{array}$ & $\begin{array}{c}62.849^{* *} \\
(31.946)\end{array}$ & $\begin{array}{c}62.587^{* *} \\
(24.364)\end{array}$ & $\begin{array}{l}73.735^{* *} \\
(36.235)\end{array}$ & $\begin{array}{c}80.738^{* * *} \\
(24.674)\end{array}$ & $\begin{array}{l}80.900^{* *} \\
(39.599)\end{array}$ \\
\hline Vulnerable $\times$ CCC & $\begin{array}{c}382.004^{* *} \\
(184.720)\end{array}$ & $\begin{array}{l}297.260 \\
(253.627)\end{array}$ & $\begin{array}{l}309.406^{*} \\
(177.172)\end{array}$ & $\begin{array}{l}243.458 \\
(217.371)\end{array}$ & $\begin{array}{l}402.316^{*} \\
(203.185)\end{array}$ & $\begin{array}{c}367.686 \\
(288.044)\end{array}$ \\
\hline Vulnerable $\times$ AAA-AA & $\begin{array}{l}12.812^{*} \\
(6.849)\end{array}$ & $\begin{array}{c}17.325^{* *} \\
(7.923)\end{array}$ & $\begin{array}{c}11.364^{* *} \\
(5.584)\end{array}$ & $\begin{array}{c}14.760^{* *} \\
(5.590)\end{array}$ & $\begin{array}{l}11.130 \\
(8.500)\end{array}$ & $\begin{array}{l}19.551^{*} \\
(10.556)\end{array}$ \\
\hline Trades $\times$ AAA & $\begin{array}{c}0.009 \\
(0.013)\end{array}$ & $\begin{array}{l}-0.017 \\
(0.015)\end{array}$ & & & & \\
\hline Trades $\times$ AA & $\begin{array}{c}0.035^{* * *} \\
(0.008)\end{array}$ & $\begin{array}{c}0.028^{* * *} \\
(0.011)\end{array}$ & & & & \\
\hline Trades $\times$ A & $\begin{array}{c}0.029^{* * *} \\
(0.007)\end{array}$ & $\begin{array}{c}0.026^{* *} \\
(0.011)\end{array}$ & & & & \\
\hline Trades $\times$ BBB & $\begin{array}{c}0.036^{* * *} \\
(0.008)\end{array}$ & $\begin{array}{c}0.036^{* * *} \\
(0.012)\end{array}$ & & & & \\
\hline Trades $\times$ BB & $\begin{array}{c}0.055^{* * *} \\
(0.009)\end{array}$ & $\begin{array}{c}0.074^{* * *} \\
(0.012)\end{array}$ & & & & \\
\hline Trades $\times$ B & $\begin{array}{c}0.109^{* * *} \\
(0.022)\end{array}$ & $\begin{array}{c}0.171^{* * *} \\
(0.039)\end{array}$ & & & & \\
\hline Trades $\times$ CCC & $\begin{array}{l}-0.023 \\
(0.114) \\
\end{array}$ & $\begin{array}{c}-0.440^{* * *} \\
(0.166) \\
\end{array}$ & & & & \\
\hline Industry-Year-Month FE & $\checkmark$ & $\checkmark$ & $\checkmark$ & $\checkmark$ & $\checkmark$ & $\checkmark$ \\
\hline Bond-level controls & $\checkmark$ & $\checkmark$ & $\checkmark$ & $\checkmark$ & $\checkmark$ & $\checkmark$ \\
\hline Sample & 2010-19 & $2013-16$ & 2010-19 & 2013-16 & 2010-19 & $2013-16$ \\
\hline Bond age & All & All & $<12$ months & $<12$ months & $>12$ months & $>12$ months \\
\hline Observations & 240,380 & 98,812 & 44,913 & 20,532 & 194,465 & 77,916 \\
\hline R-squared & 0.650 & 0.637 & 0.734 & 0.705 & 0.642 & 0.622 \\
\hline
\end{tabular}

Table D.6: Additional bond liquidity controls. This table shows the estimation results of specification (2), with tests for bond liquidity. The first two columns include additional control variables for the number of times a bond is traded in a month. We allow coefficients to vary by ratings category. In the third and fifth columns, the sample is restricted to bonds that have been issued within the past 12 months, while in the fourth and sixth columns only include bonds issued at least 12 months ago and greater. In all regressions, the dependent variable in each column is the secondary market bond spreads. Bond spreads are measured in basis points. Additional bond-level controls include residual maturity, amount outstanding and bid-ask spreads, coefficients on the latter are allowed to vary by rating. The specification also includes dummy variables for callable bonds, bonds with a price price above par but below a price of 105 and the interaction between the two variable to account for changes in credit quality affecting spreads on callable bonds. Additional dummy variables for convertible bonds, covenant bonds, and senior bonds are also included in the estimation. These control variables are included in the estimation but not reported for brevity. These specifications include industry-year-month fixed effects (2-digit SIC). Standard errors are clustered at the firm and year-month level. ${ }^{* * *} \mathrm{p}<0.01,{ }^{* *} \mathrm{p}<0.05,{ }^{*} \mathrm{p}<0.1$. 


\section{Appendix E M\&A}

\section{E.1 Additional figures}
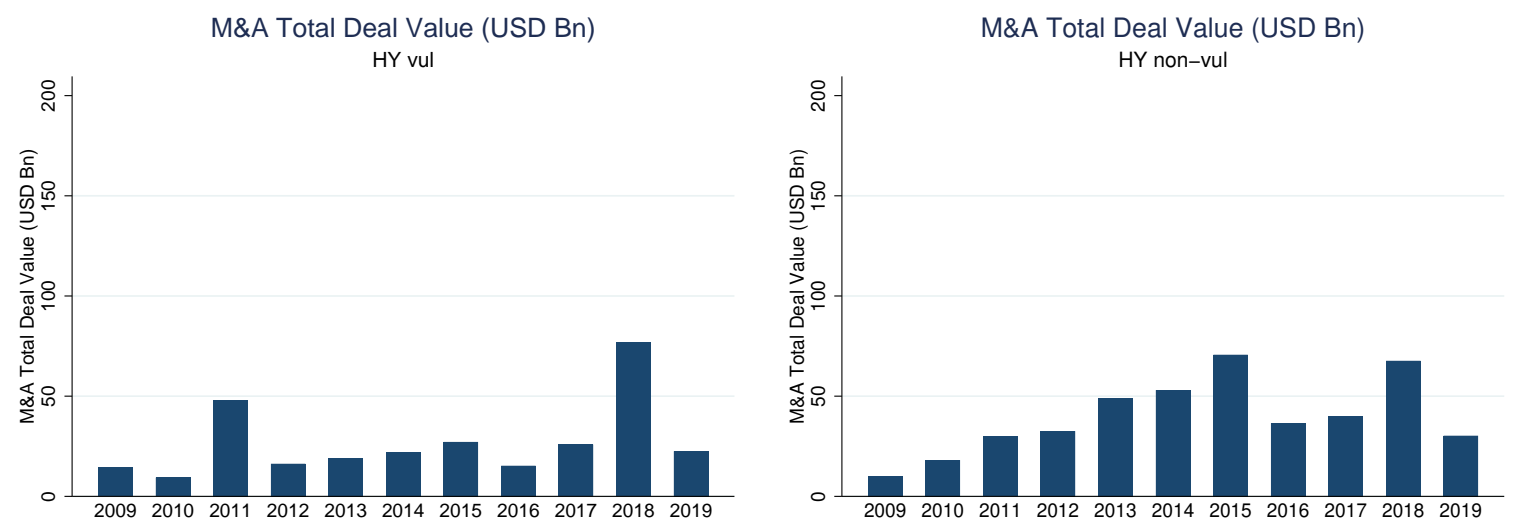

Figure E.1: M\&A Total Deal Volume. This figure shows the total M\&A deal volume for vulnerable and non-vulnerable firms in the high-yield (speculative-grade) category.
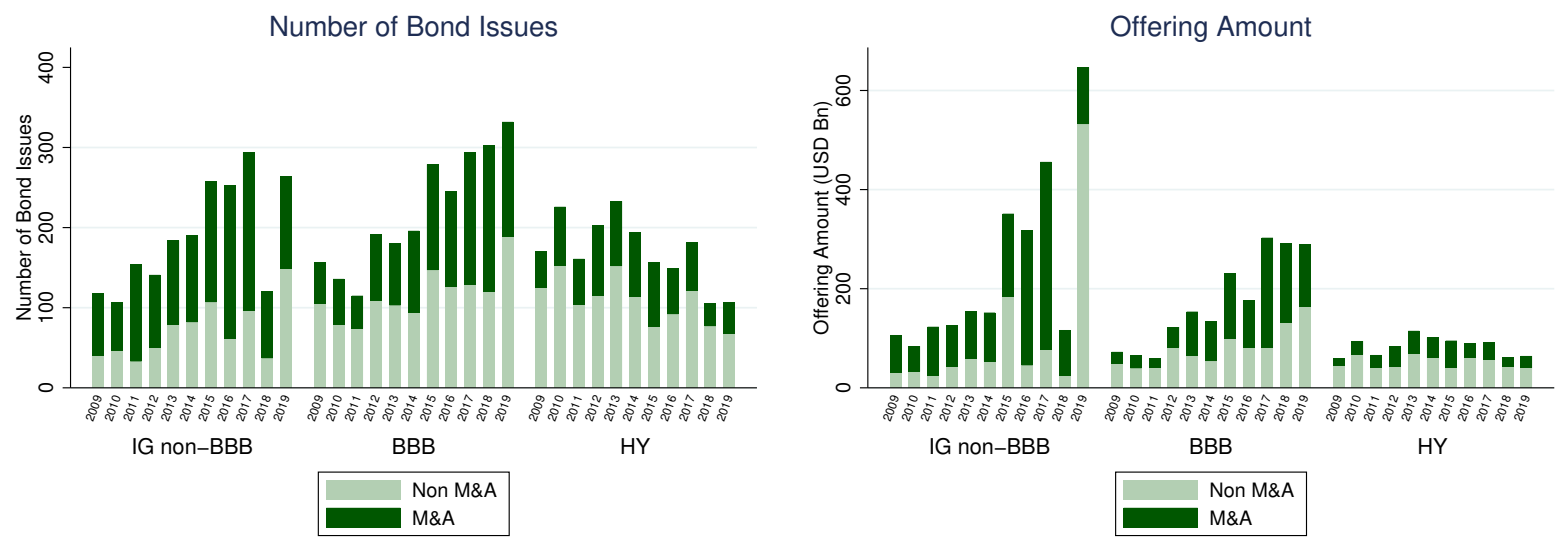

Figure E.2: Bond issuance and volume. This figure shows the number of bond issues and the bond issuance volume for high-yield, BBB-rated, and A/AA/AAA-rated firms from 2009 to 2019. The left panel shows the total number of bond issues, separated by M\&A and non-M\&A bond issues. The right panel shows the total offering amount, separated by M\&A and non-M\&A bond issues. A bond issue is considered to be M\&A-related if a firm issues a bond in the year it does at least one M\&A deal. 


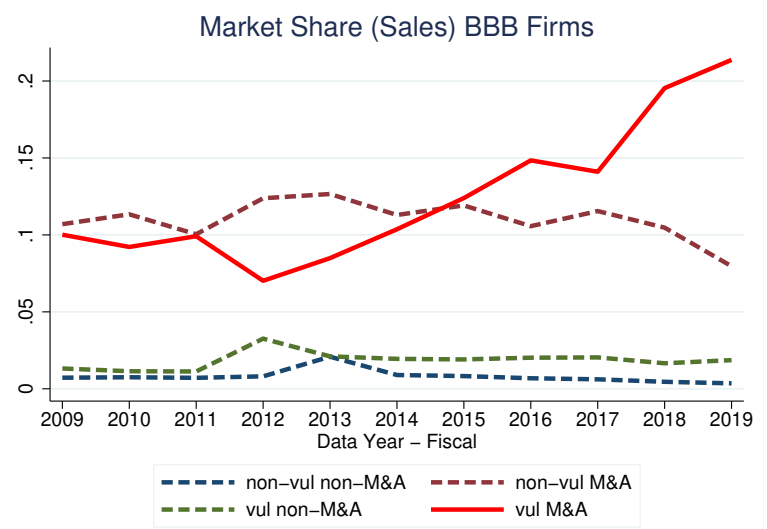

Figure E.3: M\&A and the increase in market share of prospective fallen angels. This figure shows the evolution of firm market share (share of sales, weighted by the relative size of the respective industry)) for BBB-rated issuers, broken down by downgrade-vulnerability and whether a firm engages in an M\&A transaction during our sample period.

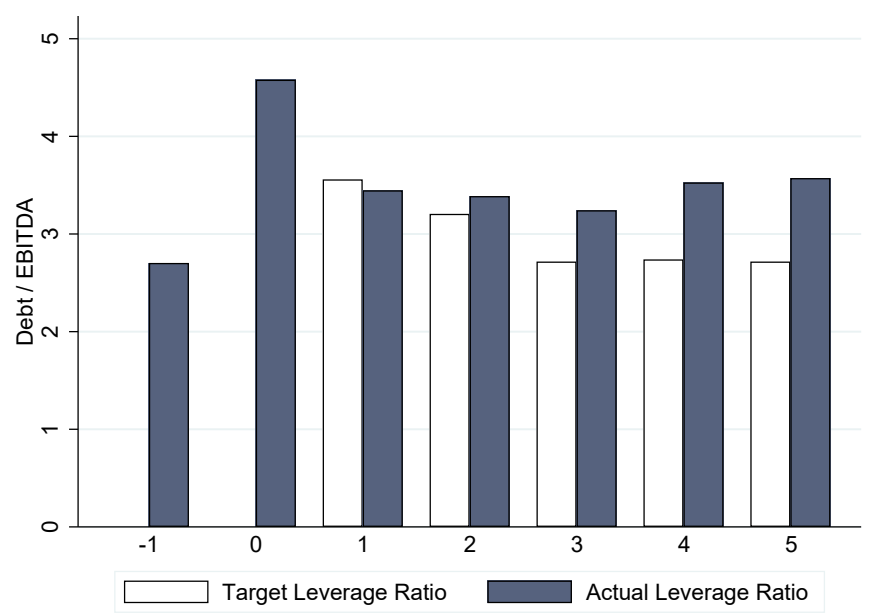

Figure E.4: Broken promises about debt reduction after M\&A. This figure compares the year-byyear promised path of debt reduction with observed debt after firm M\& A. The x-axis shows the years since transaction. The y-axis is debt divided by EBITDA. We assume that debt reduction plans (e.g., leverage from 10 to 5 in 5 years) have a linear schedule (i.e., leverage of 6 next year). In the case a target year is not specified, we assume a two-year deadline (the modal deadline). Source: data collected by the author from firms' official presentations, press releases, investor calls, and Fitch ratings. 

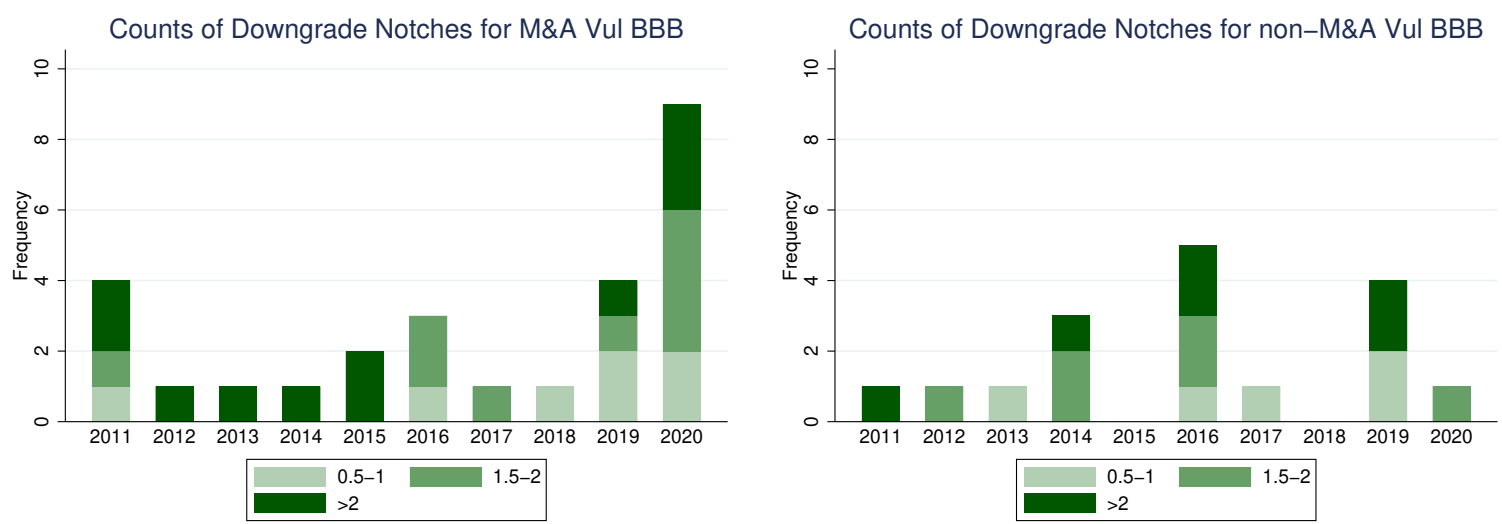

Figure E.5: Downgrade materialization of (prospective) fallen angels. This figure shows the number of downgrades that vulnerable BBB-rated firms have experienced in the years 2011 to 2020 , and groups them according to their downgrade severity. The downgrade severity is measured by the number of notches a firm is being downgraded, and is subdivided into three broad categories: 0.5-1, 1.5-2, >2 notches. The left-hand panel plots the downgrade (notch) frequency for vulnerable BBB firms that have conducted an M\&A since the year that they have become vulnerable. The right-hand panel shows the downgrade (notch) frequency for firms that have not conducted an M\&A since the year that they have become vulnerable.

\section{E.2 M\&A risk-taking}

In this section, we show that prospective fallen angels conduct larger M\&A transactions relative to their size, use higher leverage relative to their profitability level and have more negative CARs compared to non-vulnerable firms. More specifically, we estimate the following specification:

$$
\begin{aligned}
Y_{i h t} & =\beta_{1} \text { Vulnerable }_{i h t}+\beta_{2} B B B_{i h t}+\beta_{3} \text { Vulnerable }_{i h t} \times B B B_{i h t} \\
& +\gamma \times X_{i h t}+\eta_{h t}+\epsilon_{i h t},
\end{aligned}
$$

where $i$ is a firm, $h$ an industry, and $t$ a year. $Y_{i h t}$ measures the relative deal size, net debt/EBITDA (adjusted to $Y_{i h t+1}$ ) and CARs (adjusted to deal level). The coefficient $\beta_{1}$ captures the effect of a firm's vulnerable status on the dependent variable. The coefficient $\beta_{2}$ captures the effect of a firm's BBB rating on the dependent variable. The coefficient $\beta_{3}$ captures whether the effect of a firm vulnerable status on the dependent variable is different for BBB rated firms compared with non-BBB rated firms. We include industry-year fixed effects to absorb time-varying industry level heterogeneity (e.g., demand shocks) and time-varying firm level controls. 


\begin{tabular}{|c|c|c|c|}
\hline & Relative Deal Size iht & Net Debt/EBITD $A_{i h t+1}$ & $C A R s_{i j h t}$ \\
\hline \multirow[t]{2}{*}{ Vulnerable $\times$ BBB } & $0.055^{* *}$ & $0.373^{*}$ & $-0.010^{*}$ \\
\hline & $(0.025)$ & $(0.212)$ & $(0.005)$ \\
\hline \multirow[t]{2}{*}{ Vulnerable } & $-0.033^{* *}$ & -0.263 & 0.003 \\
\hline & $(0.015)$ & $(0.183)$ & $(0.004)$ \\
\hline \multirow[t]{2}{*}{$\mathrm{BBB}$} & $-0.045^{* * *}$ & $-0.222^{*}$ & 0.001 \\
\hline & $(0.013)$ & $(0.125)$ & $(0.003)$ \\
\hline Controls & $\checkmark$ & $\checkmark$ & $\checkmark$ \\
\hline Industry-Year FE & $\checkmark$ & $\checkmark$ & $\checkmark$ \\
\hline Sample & M\&A Rated & M\&A Rated & M\&A Rated \\
\hline Level & Firm & Firm & Deal \\
\hline Observations & 1,840 & 2,625 & 2,412 \\
\hline R-squared & 0.261 & 0.470 & 0.197 \\
\hline
\end{tabular}

Table E.1: $\quad$ M\&A and risk-taking. This table presents the risk-taking of vulnerable BBB-rated firms in the year of $(t)$ and after $(t+1)$ the announced M\&A transaction. Column (1) shows the results for the relative deal size, which is measured by the total transaction value of a firm in a given year over its lagged assets. We restrict our sample to firm-years with total transaction value bigger than zero. Column (2) shows the net debt/EBITDA levels for the M\&A rated firms in the year after the M\&A announcement. For Column (1) and (2) the firm controls consist of the log of assets, profitability, leverage and tangibility. Column (3) presents the 5-day cumulative abnormal returns for the M\&A deals performed by the rated firms in our sample, for which we run the specification on a deal level. The total return value-weighted index is used as benchmark over a -210 to -11 day period. Control variables include the logarithm of total assets, leverage, profitability, an indicator variable for whether the deal is at least partially financed with stock, an indicator variable for whether the target has the same 2-digit SIC code as the acquiror, an indicator variable for whether the deal is cross-border, an indicator variable for a publicly listed target and the pre-deal buy-and-hold returns of the acquiror from -210 to - 11 days. A $t$-test shows that on average the CARs of BBB vulnerable firms are -1 per cent. All specifications include industry-year fixed effects. Standard errors are clustered at the firm level.

\section{E.3 Exorbitant privilege largely driven by M\&A}

In this section, we document that the low bond financing costs of prospective fallen angels is particularly pronounced for issuers engaging in M\&A activity.

We revisit our bond pricing analysis and show that the bond financing privilege of prospective fallen angels is largely driven by M\&A. To do so, we modify specification (2) to examine the change in bond spreads around M\&A announcements by estimating the following specification which includes interactions with an M\&A variable:

$$
\begin{aligned}
& \Delta_{12} \text { Spread }_{b i t}=\beta_{1}{\mathrm{M} \& \mathrm{~A}_{i t-11}} \times \text { Vulnerable }_{i t-11} \times \text { Rating }_{i t-11} \\
& +\boldsymbol{\beta}_{\mathbf{2}} \text { Vulnerable }_{i t-11} \times \text { Rating }_{i t-11} \\
& +\boldsymbol{\beta}_{\mathbf{3}} \mathrm{M} \& \mathrm{~A}_{i t-11} \times \boldsymbol{R a t i n g}_{i t-11}+\boldsymbol{\delta} \boldsymbol{X}_{b t-11}+\boldsymbol{\nu}_{r j t}+\epsilon_{b i t}
\end{aligned}
$$

where $\Delta_{12}$ Spread $_{b i t}$ is the change in the secondary market spread on bond $b$ issued by firm $i$

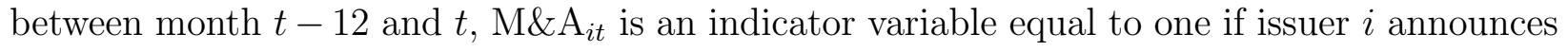
an M\&A deal in month $t$, and Rating $_{i t}$ is a vector of dummy variables corresponding to the credit rating of firm $i$ in month $t$. We also include the same bond-level controls as in specification (2) $\boldsymbol{X}_{\boldsymbol{b} \boldsymbol{t}}$ and rating-industry-year-month fixed effects $\boldsymbol{\nu}_{r j t}$.

Table E.2 shows the estimation results. The significant triple interaction terms of M\&A $\times$ Vulnerable $\times$ BBB confirm that secondary market spreads on bonds issued by prospective 


\begin{tabular}{|c|c|c|}
\hline & $\Delta_{12}$ Spread & $\Delta_{12}$ Spread \\
\hline Vulnerable $_{i t-11} \times \mathrm{AAA} \mathrm{AA}_{i t-11}$ & $\begin{array}{c}-4.197^{* * *} \\
(0.899)\end{array}$ & $\begin{array}{c}-4.018^{* * *} \\
(0.265)\end{array}$ \\
\hline Vulnerable $_{i t-11} \times \mathrm{A}_{i t-11}$ & $\begin{array}{c}0.294 \\
(1.320)\end{array}$ & $\begin{array}{c}1.474 \\
(2.481)\end{array}$ \\
\hline Vulnerable $_{i t-11} \times \mathrm{BBB}_{i t-11}$ & $\begin{array}{c}0.553 \\
(0.964)\end{array}$ & $\begin{array}{l}-1.976 \\
(1.740)\end{array}$ \\
\hline Vulnerable $_{i t-11} \times \mathrm{BB}_{i t-11}$ & $\begin{array}{l}1.897 \\
(5.183)\end{array}$ & $\begin{array}{l}4.984 \\
(6.577)\end{array}$ \\
\hline Vulnerable $_{i t-11} \times \mathrm{B}_{i t-11}$ & $\begin{array}{l}21.853^{*} \\
(13.078)\end{array}$ & $\begin{array}{l}23.897^{*} \\
(13.176)\end{array}$ \\
\hline 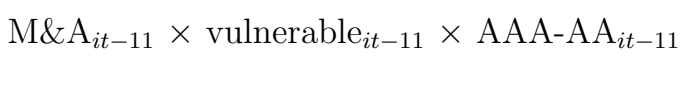 & $\begin{array}{l}6.229^{* *} \\
(2.462)\end{array}$ & $\begin{array}{c}8.295^{* * *} \\
(0.860)\end{array}$ \\
\hline 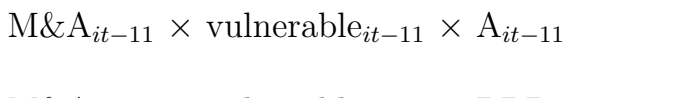 & $\begin{array}{c}1.146 \\
(1.503)\end{array}$ & $\begin{array}{l}1.941 \\
(2.148)\end{array}$ \\
\hline 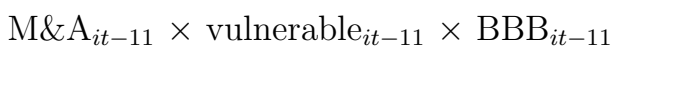 & $\begin{array}{l}-2.369 \\
(2.063)\end{array}$ & $\begin{array}{c}-6.399 * * \\
(3.147)\end{array}$ \\
\hline 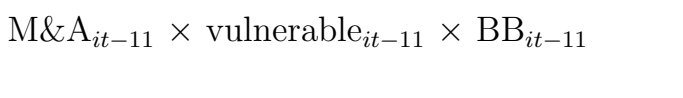 & $\begin{array}{c}29.558^{* * *} \\
(10.957)\end{array}$ & $\begin{array}{c}40.129 * * * \\
(14.127)\end{array}$ \\
\hline 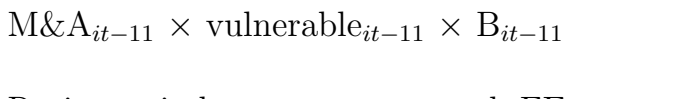 & $\begin{array}{c}-7.472 \\
(40.912)\end{array}$ & $\begin{array}{c}47.515 \\
(57.013)\end{array}$ \\
\hline Rating $\times$ industry $\times$ year-month $\mathrm{FE}$ & $\checkmark$ & $\checkmark$ \\
\hline Rating $\times$ M\&A controls & $\checkmark$ & $\checkmark$ \\
\hline Sample period & Entire & $2013-16$ \\
\hline Observations & 66000 & 33170 \\
\hline R-squared & 0.790 & 0.778 \\
\hline
\end{tabular}

Table E.2: Prospective fallen angels subsidy and M\&A activity. This table presents estimation results from specification (E2). The dependent variable is the change in the spread of bond $b$ issued by firm $i$ between month $t-12$ and $t$. Vulnerable is a dummy equal to 1 if firm $i$ is vulnerable to a downgrade at date $t$ and zero otherwise. M\&A is a dummy variable equal to one if issuer $i$ announces an M\&A acquisition in month $t$ and zero otherwise. The interactions between the M\&A dummy and issuer ratings are included in the estimation but not reported for brevity. The specification also includes dummy variables for callable bonds, bonds with a price above par but below a price of 105 and the interaction between the two variable to account for changes in credit quality affecting spreads on callable bonds. Dummy variables for convertible bonds, covenant bonds, and senior bonds are included in the estimation but not reported for brevity. Standard errors clustered at the firm level and reported in parentheses. ${ }^{* *} \mathrm{p}<0.01,{ }^{* *} \mathrm{p}<0.05,{ }^{*} \mathrm{p}<0.1$.

fallen angels decline around M\&A announcements relative to bonds issued by prospective fallen angels that did not announce an M\&A. The second column shows that the privilege was larger during the period of large QE purchases. Consistent with the privilege being only present for prospective fallen angels, downgrade-vulnerable firms in other ratings segments do not experience a decline in spreads after M\&A announcements. 


\section{E.4 The sluggishness of credit ratings}

We now formally document that BBB-rated firms are less likely to experience a downgrade, at least in the short-term, if they engage in M\&A. Formally, we estimate the following specification in the subsample of downgrade-vulnerable firms:

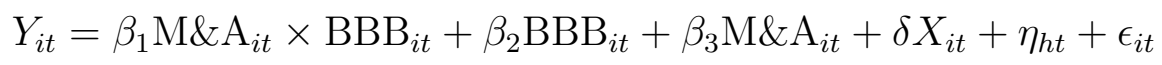

where $i$ is a firm and $t$ is year. The dependent variable $Y_{i t}$ is ratings inflation, defined as the number of notches between the issuer's credit rating notch and the credit rating notch implied by its Z"-score. The independent variable of interest is the interaction between $B B B_{i t}$ and $M \& \mathrm{~A}_{i t}$, where $M \& \mathrm{~A}_{i t}$ is a dummy equal to one in the year firm $i$ has conducted an M\&A deal and for the years thereafter. $B B B_{i t}$ is a dummy equal to one if firm $i$ has a BBB rating in $t . X_{i t}$ represents a set of firm controls (log assets, leverage, and net worth) and $\eta_{h t}$ are industry-year fixed effects.

Table E.3 shows the estimation results. The first column suggests that prospective fallen angels enjoy an additional 0.4 notches in ratings inflation compared with downgrade-vulnerable issuers in other rating groups. The second column shows that, within downgrade-vulnerable firms, ratings inflation is largely driven by firms that have undertaken an M\&A. This M\&A ratings inflation is, however, only enjoyed by prospective fallen angels.

The last four columns further confirm the interplay between M\&A and the leniency of credit rating agencies. For this analysis, we track a firm from the first moment it is considered to be downgrade-vulnerable within a rating, until the year it is either upgraded or downgraded. This window is referred to as the downgrade-vulnerability window, and runs from $t_{0}=0$ until $t_{h}=h$, where $h$ is the length of the window. We drop firms that never enter the downgrade-vulnerability status or that never encounter a rating change.

We mark the downgrade-vulnerability window to be "M\&A related" if a firm has conducted at least one M\&A transaction while being downgrade-vulnerable within the $\left(t_{0}, t_{h}\right)$ interval. We furthermore construct (i) a variable that denotes the $t_{0}$ rating, (ii) a variable that denotes the years it took the firm to be upgraded/downgraded (equal to $h$ ), (iii) an indicator variable equal to one if a firm is downgraded at time $h$, (iv) an indicator variable equal to one if a firm is upgraded at time $h$, and (v) a variable that denotes the downgrade severity, measured by the number of notches a firm is being downgraded at time $h$.

We then collapse the downgrade-vulnerability window to the year in which the rating change occurs, and are thus effectively left with the cross-section of rating changes $j$ of firm $i$. This subsample allows us to study the rating dynamics of BBB M\&A firms relative to non-M\&A firms. Specifically, we estimate the following specification:

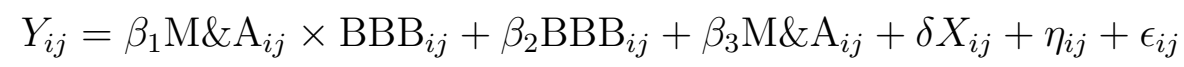

where $i$ is a firm and $j$ is the rating change. The dependent variable $Y_{i j}$ denotes a set of variables: i) the upgrade/downgrade probability, which is a dummy variable equal to one in case of a upgrade/downgrade at time $h$, ii) the upgrade/downgrade intensity measured by the notches upgraded/downgraded at time $h$, and iii) the time to downgrade which is equal to $h . M \& A_{i j}$ is a dummy equal to one when a firm has done an M\&A deal within the $\left(t_{0}, t_{h}\right)$ interval. $B B B_{i j}$ is a dummy equal to one if firm $i$ has a BBB rating at time $t_{0} . X_{i j}$ 


\begin{tabular}{|c|c|c|c|c|c|c|}
\hline & $\begin{array}{l}\text { Rating } \\
\text { inflation }\end{array}$ & $\begin{array}{l}\text { Rating } \\
\text { inflation }\end{array}$ & $\begin{array}{l}\text { Downgrade } \\
\text { probability }\end{array}$ & $\begin{array}{c}\text { Time to } \\
\text { downgrade }\end{array}$ & $\begin{array}{c}\text { Upgrade } \\
\text { probability }\end{array}$ & $\begin{array}{c}\text { Up/Downgrade } \\
\text { intensity }(\Delta \text { notch })\end{array}$ \\
\hline $\mathrm{BBB}_{i t}$ & $\begin{array}{c}0.380^{* *} \\
(0.188)\end{array}$ & $\begin{array}{c}0.016 \\
(0.288)\end{array}$ & $\begin{array}{c}-0.069^{* *} \\
(0.032)\end{array}$ & $\begin{array}{c}-0.677^{* * *} \\
(0.244)\end{array}$ & $\begin{array}{l}-0.026 \\
(0.019)\end{array}$ & $\begin{array}{c}0.003 \\
(0.082)\end{array}$ \\
\hline $\mathrm{M} \& \mathrm{~A}_{i t} \times \mathrm{BBB}_{i t}$ & & $\begin{array}{l}0.566^{*} \\
(0.302)\end{array}$ & $\begin{array}{c}-0.082^{* *} \\
(0.038)\end{array}$ & $\begin{array}{l}-0.176 \\
(0.290)\end{array}$ & $\begin{array}{l}0.070^{* *} \\
(0.033)\end{array}$ & $\begin{array}{c}-0.250^{* * *} \\
(0.093)\end{array}$ \\
\hline $\mathrm{M} \& \mathrm{~A}_{i t}$ & & $\begin{array}{l}-0.318 \\
(0.199)\end{array}$ & $\begin{array}{l}0.043^{*} \\
(0.024)\end{array}$ & $\begin{array}{l}0.533^{*} \\
(0.270)\end{array}$ & $\begin{array}{l}-0.036^{*} \\
(0.019)\end{array}$ & $\begin{array}{l}0.104^{*} \\
(0.059)\end{array}$ \\
\hline Industry-Year FE & $\checkmark$ & $\checkmark$ & $\checkmark$ & $\checkmark$ & $\checkmark$ & $\checkmark$ \\
\hline Controls & $\checkmark$ & $\checkmark$ & $\checkmark$ & $\checkmark$ & $\checkmark$ & $\checkmark$ \\
\hline Sample & $\begin{array}{l}\text { Vulnerable } \\
\text { Entire }\end{array}$ & $\begin{array}{l}\text { Vulnerable } \\
\text { Entire }\end{array}$ & $\begin{array}{c}\text { Vulnerable } \\
\text { Rating changes }\end{array}$ & $\begin{array}{c}\text { Vulnerable } \\
\text { Downgrades }\end{array}$ & $\begin{array}{c}\text { Vulnerable } \\
\text { Rating changes }\end{array}$ & $\begin{array}{c}\text { Vulnerable } \\
\text { Rating changes }\end{array}$ \\
\hline $\begin{array}{l}\text { Observations } \\
\text { R-squared }\end{array}$ & $\begin{array}{l}2,750 \\
0.381\end{array}$ & $\begin{array}{l}2,750 \\
0.386\end{array}$ & $\begin{array}{c}255 \\
0.616\end{array}$ & $\begin{array}{c}143 \\
0.723\end{array}$ & $\begin{array}{c}255 \\
0.505\end{array}$ & $\begin{array}{c}255 \\
0.543\end{array}$ \\
\hline
\end{tabular}

Table E.3: The role of M\&A in prolonging ratings inflation. This table presents firm-level regressions for vulnerable firms. In the left-hand panel, we focus on the entire sample. The dependent variable is rating inflation - calculated as the number of notches between the issuer's credit rating notch (e.g., AA+, AA, AA-, A) and the credit rating notch implied by its Z"-score. M\&A is a dummy variable equal to one for the year and the years after a firm has conducted M\&A. In the right-hand panel, we restrict our sample to all firm-years with rating changes (or downgrades). In these regressions M\&A takes the value of one if - between rating changes - a firm has done an M\&A deal while being vulnerable. The dependent variables include i) downgrade probability, which is a dummy variable equal to one in case of a downgrade by at least one rating category, ii) time to downgrade, which measures the time between the first time a firm is considered to be vulnerable after a rating change, up until the next rating change, iii) upgrade probability, which is a dummy variable equal to one in case of an upgrade by at least one rating category, and iv) downgrade intensity which measures the number of notches a firm is up- or downgraded. A positive number refers to a downgrade, and a negative number to an upgrade. The dependent variables are weighted by the total debt outstanding in a rating category in a given year. All specifications include industry-year fixed effects and firm-level controls (including $\log$ (total assets), leverage, net worth and tangibility (ppent / assets)). Standard errors are clustered at the firm level. ${ }^{* * *} \mathrm{p}<0.01,{ }^{* *} \mathrm{p}<0.05,{ }^{*} \mathrm{p}<0.1$.

represents a set of firm controls (log of total assets, leverage and tangibility) at time $h$ and $\eta_{i j}$ are industry-year fixed effects at time $h$.

The third column shows that, while downgrade-vulnerable firms that undertake M\&A have a higher probability of being downgraded, prospective fallen angels that undertake M\&A have a lower probability of being downgraded, consistent with a leniency of credit rating agencies. In the fourth column, we further restrict the sample to include only downgrades. We find that, conditional on being downgraded, M\&A extends the time-to-downgrade in all rating categories.

The inherent riskiness of M\&A might be, ex-post, good news for the downgrade-vulnerable firm. The last two columns of the table likely capture these cases. The fifth column shows that, for prospective fallen angels, M\&A provides an upside potential, estimated as an increased upgrade probability. This upside potential is confirmed in the last column, where the negative coefficient of the interaction term captures a higher upgrade intensity relative to other M\&A firms. However, in the remainder of this section, we show that M\&A causes a buildup in vulnerability, which materialized at the onset of the COVID-19 pandemic.

Table E.4 confirms that the COVID-19 shock particularly affected prospective fallen angels that engaged in M\&A. We augment specification (E4) to include a triple interaction with a time dummy equal to one in 2020. In the first column, the sum of the coefficients of $M \& A$ and $M \& A \times 2020$ shows that M\&As do not in general affect the probability of being downgraded 


\begin{tabular}{|c|c|c|c|c|}
\hline & $\begin{array}{l}\text { Downgrade } \\
\text { probability }\end{array}$ & $\begin{array}{l}\text { Upgrade } \\
\text { probability }\end{array}$ & $\begin{array}{c}\text { Up/Downgrade } \\
\text { intensity }(\Delta \text { notch })\end{array}$ & $\begin{array}{c}\text { Time to } \\
\text { downgrade }\end{array}$ \\
\hline \multirow[t]{2}{*}{ 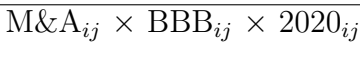 } & $0.233^{* * *}$ & -0.051 & $0.441^{* *}$ & $1.034^{*}$ \\
\hline & $(0.068)$ & $(0.050)$ & $(0.170)$ & $(0.566)$ \\
\hline \multirow{2}{*}{$\mathrm{M} \& \mathrm{~A}_{i j} \times 2020_{i j}$} & $-0.065^{*}$ & 0.006 & -0.022 & $-0.965^{* *}$ \\
\hline & $(0.037)$ & $(0.032)$ & $(0.125)$ & $(0.437)$ \\
\hline \multirow[t]{2}{*}{$\mathrm{M} \& \mathrm{~A}_{i j} \times \mathrm{BBB}_{i j}$} & $-0.124^{* * *}$ & $0.090^{* *}$ & $-0.328^{* * *}$ & -0.459 \\
\hline & $(0.046)$ & $(0.043)$ & $(0.115)$ & $(0.408)$ \\
\hline \multirow[t]{2}{*}{$\mathrm{BBB}_{i j} \times 2020_{i j}$} & $-0.130^{* *}$ & -0.023 & $-0.273^{* *}$ & -0.512 \\
\hline & $(0.052)$ & $(0.032)$ & $(0.123)$ & $(0.435)$ \\
\hline \multirow{2}{*}{$\mathrm{BBB}_{i j}$} & $-0.056^{*}$ & -0.025 & 0.023 & $-0.579^{* *}$ \\
\hline & $(0.032)$ & $(0.020)$ & $(0.082)$ & $(0.245)$ \\
\hline \multirow[t]{2}{*}{${\mathrm{M} \& \mathrm{~A}_{i j}}$} & $0.055^{* *}$ & $-0.038^{*}$ & 0.109 & $0.772^{* *}$ \\
\hline & $(0.028)$ & $(0.023)$ & $(0.068)$ & $(0.357)$ \\
\hline Industry-Year FE & $\checkmark$ & $\checkmark$ & $\checkmark$ & $\checkmark$ \\
\hline Controls & $\checkmark$ & $\checkmark$ & $\checkmark$ & $\checkmark$ \\
\hline \multirow[t]{2}{*}{ Sample } & Vulnerable firms & Vulnerable firms & Vulnerable firms & Vulnerable firms \\
\hline & Rating changes & Rating changes & Rating changes & Downgrades \\
\hline Observations & 255 & 255 & 255 & 143 \\
\hline R-squared & 0.625 & 0.512 & 0.550 & 0.736 \\
\hline
\end{tabular}

Table E.4: Downgrades and upgrades following M\&A. This table presents estimation results from the augmented specification (E4). The dependent variables are downgrade probability, upgrade probability, time to downgrade and downgrade intensity, weighted by the total debt amount in a rating category in a given year. Downgrade / upgrade probability are dummy variables which take the value of one in case of a downgrade / upgrade. Downgrade / upgrade intensity measures the number of notches a firm is downgraded / upgraded, if downgraded / upgraded by at least one rating category. A positive number refers to a downgrade, and a negative number to an upgrade. Time to downgrade measures the time it took a firm to downgrade after obtaining the vulnerability status. Control variables include the log of total assets, leverage and tangibility (ppent / assets). For columns (1), (2), and (3), the sample consists of vulnerable firms that have experienced a rating change. Column (4) focuses on vulnerable firms that have been downgraded. Standard errors are clustered at the firm-level and reported in parentheses. ${ }^{* * *} \mathrm{p}<0.01,{ }^{* *} \mathrm{p}<0.05,{ }^{*} \mathrm{p}<0.1$.

in 2020. However, the incremental effect of $M \& A \times B B B$ and $M \& A \times B B B \times 2020$ shows that this is not the case for the $\mathrm{BBB}$ rating. Rather, the results show that the downgrade risk of prospective fallen angels in 2020 is larger and materializes in an economic downturn. Importantly, the second column shows that the COVID-19 pandemic did not affect the upgrade probability of prospective fallen angels in 2020 .

In the third column, we replace the probability of upgrades and downgrades by their intensity, measured by the number of notches a firm is upgraded or downgraded. A positive number refers to a downgrade, and a negative number to an upgrade. The sum of the coefficients $M \& A \times B B B$ and $M \& A$ shows that, in the years prior to the COVID-shock, prospective fallen angels that conducted $\mathrm{M} \& \mathrm{~A}$ deals have a greater upgrade intensity, echoing the results of Table E.3. However, once the COVID-shock hits the economy, the pattern reverses. In 2020, prospective fallen angels have not only been downgraded more often, but have also been downgraded by more notches.

Finally, we provide suggestive evidence linking the downgrades of prospective fallen angels in 2020 to the leniency of credit rating agencies. Specifically, we examine the time-todowngrade for downgrade-vulnerable firms in 2020. In the last column, we observe that it took longer to be downgraded for prospective fallen angels that did an M\&A deal. These results suggest that the BBB-rated firms that fell to the speculative-grade market in 2020 
might have benefited from the leniency of credit rating agencies during the pre-pandemic years. However, once the COVID-19 shock hit the economy, we observed a massive amount of debt being downgraded to the speculative-grade market, as shown in Figure 13. 


\section{Appendix F Quantifying the subsidy}

To compute the subsidy for the prospective fallen angels, we multiply the mean difference between the offering spread of bonds of downgrade-vulnerable BBB firms and the offering spread of bonds of matched BB firms by the average bond maturity and the total offering amount in the vulnerable BBB rating bucket in a given year, and sum over our 2009 to 2019 sample period. To ensure the robustness of our mean spread difference based on our matched sample, we estimate the mean spread difference for various matching score cutoffs. As shown in Figure F.1, the spread difference is stable across the different score cutoffs, and thus does not lead to material differences in our total subsidy estimate.

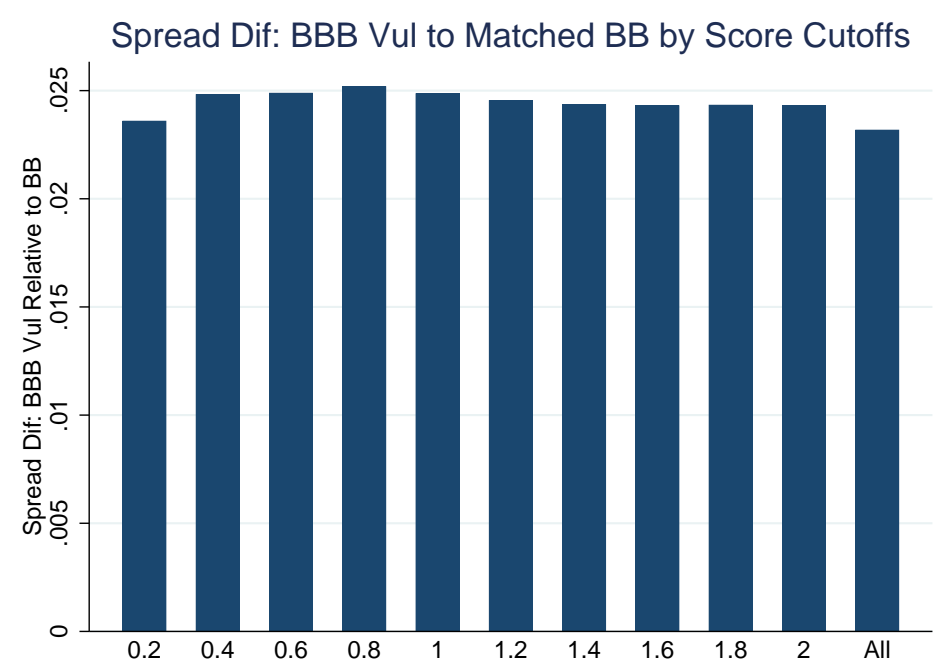

Figure F.1: Spread difference vulnerable BBB to matched BB across different score cutoffs. This figure shows the mean difference between the offering spread of bonds of BBB downgrade-vulnerable firms and the offering spread of bonds of matched BB firms within the same industry-year. 


\section{Appendix G Additional figures and tables}
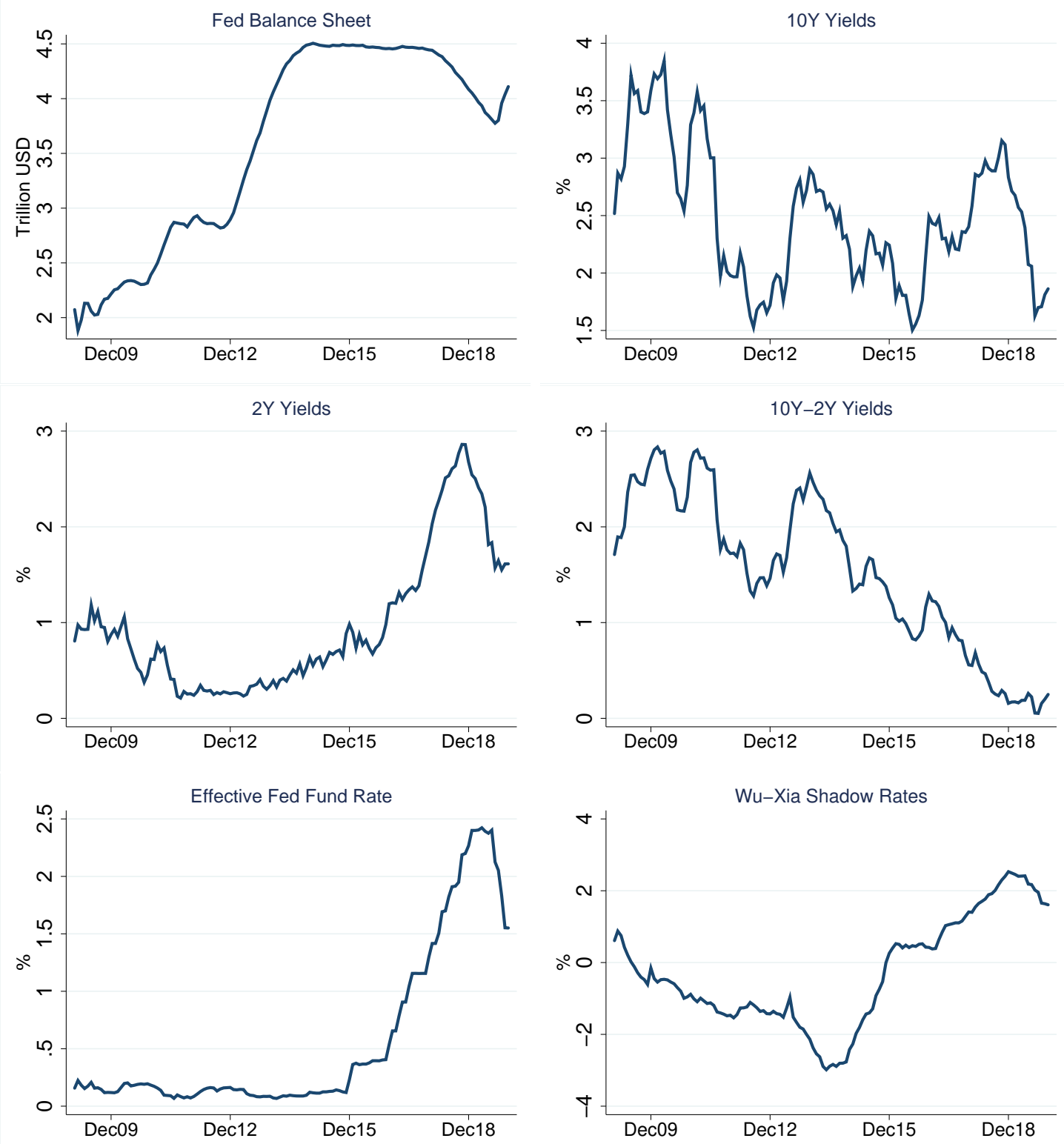

Figure G.1: Monetary policy stance. This figure shows the monetary policy stance in the U.S. during our sample period. The six panels show the size of the Fed balance sheet (trillion dollars), the 10-year Treasury yields (\%), the 2-year Treasury yields (\%), the difference between the 10-year and the 2-year Treasury yields, the effective fed fund rate, and the shadow rate developed in Wu and Xia (2016). The series are plotted with observations at a monthly frequency. The 10-year yields, the 2-year yields, and the effective fed fund rate are monthly averages of daily data. The fed balance sheet size is the monthly average of weekly data. 


\section{Aggregate evidence}
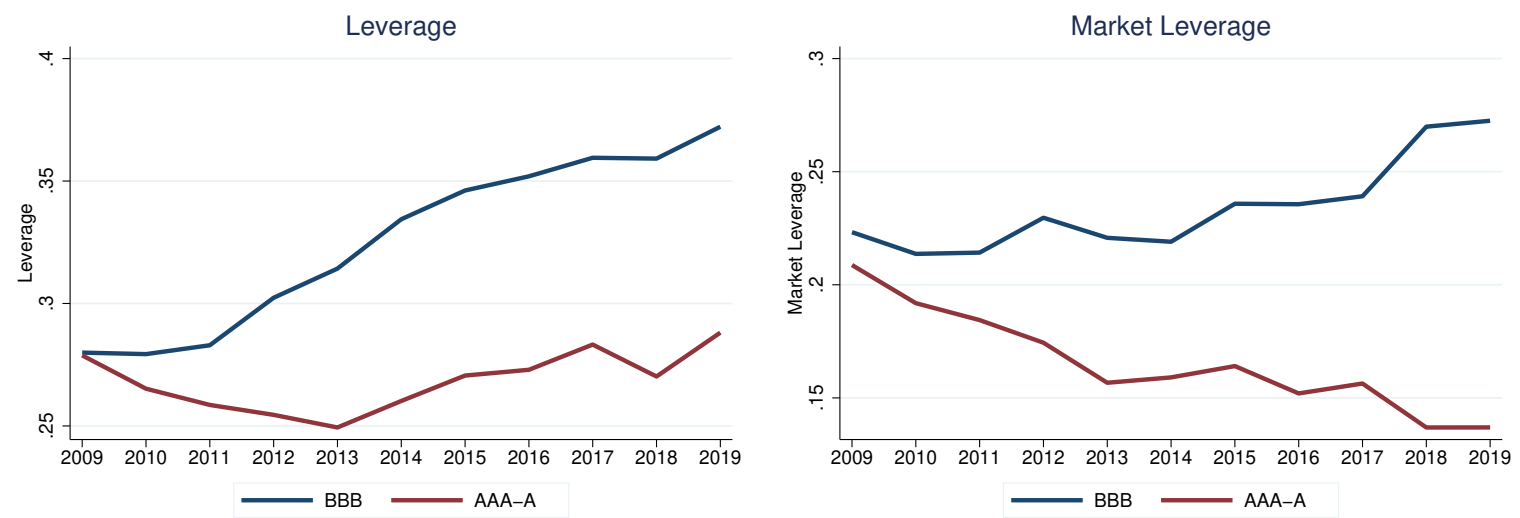

Figure G.2: Leverage over Time. This figure shows the leverage evolution for BBB and IG-rated firms over the years 2009 to 2019. In Panel A, we show the asset-weighted book leverage, which is defined by a firm's total debt over assets. In Panel B, we show the asset-weighted market leverage, which is defined by a firm's total debt over the market value of its assets. 


\section{Compression of BBB spreads}

We provide further evidence that the bond financing cost of BBB firms dropped significantly, and more than the financing costs of other investment grade issuers, since 2009. In Figure G.3, we show the compression of bond spreads by tracking the distribution of primary market spreads (top panel) and secondary market spreads (bottom panel) from 2010-12 (dashed lines) to 2013-16 (solid lines). The left panels compare the distribution of BBB bond spreads with the distribution of A bond spreads. The right panels compare the distribution of BBB bond spreads with the distribution of AA bond spreads. The four panels document a pronounced leftward shift of BBB spreads in the primary and the secondary market. If anything, we observe a slight rightward shift for A and AA spreads. In Figure G.1, we show that the 2013-16 is characterized by a substantial monetary easing by the Federal Reserve.
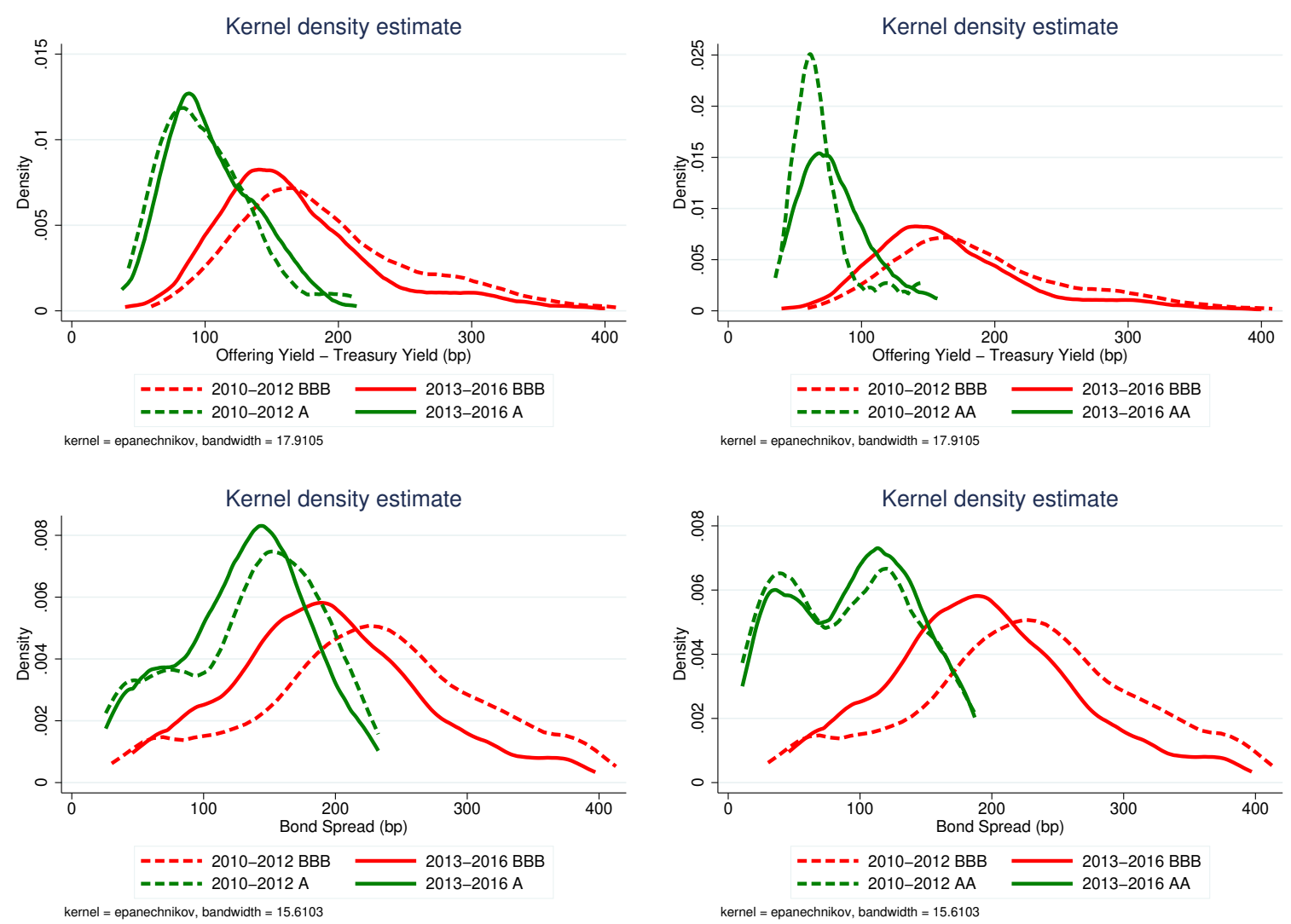

Figure G.3: Shift in bond spread distributions from 2010-12 to 2013-16. This figure shows how bond spreads distributions changed from 2010-12 (dashed lines) to 2013-16 (solid lines). The top panels show the distribution of offering spreads for newly issued bonds. The bottom two panels show the distribution of secondary market spreads for traded bonds. The left and right panels compare the distributions of BBB bond spreads (red lines) with the distributions of A bond spreads and AA bond spreads (green lines), respectively. 


\begin{tabular}{lcc} 
& $\mathrm{N}$ & $\sum_{k}$ Asset $_{k}^{2009 q 1}$ \\
\hline Annuities & 237 & $\$ 30.088$ billion \\
Life \& Health Insurance & 652 & $\$ 261.926$ billion \\
Property \& Casualty Insurance & 1322 & $\$ 61.278$ billion \\
Open Ended Mutual Funds & 596 & $\$ 174.841$ billion \\
\hline
\end{tabular}

\begin{tabular}{lccccc} 
QE Exposure $_{k t}$ & mean & stdev & $\mathrm{p} 25$ & $\mathrm{p} 50$ & $\mathrm{p} 75$ \\
\hline Annuities & 0.063 & 0.011 & 0.060 & 0.065 & .070 \\
Life \& Health Insurance & 0.031 & 0.005 & 0.029 & 0.031 & 0.035 \\
Property \& Casualty Insurance & 0.054 & 0.007 & 0.048 & 0.055 & 0.060 \\
Open Ended Mutual Funds & 0.050 & 0.008 & 0.045 & 0.049 & 0.057 \\
\hline
\end{tabular}

\begin{tabular}{lccccc} 
Corporate and Treasury Bond Portfolio Maturity & mean & stdev & p25 & p50 & p75 \\
\hline Annuities & 8.993 & 0.389 & 8.626 & 8.916 & 9.296 \\
Life \& Health Insurance & 11.332 & 0.377 & 11.020 & 11.332 & 11.617 \\
Property \& Casualty Insurance & 5.882 & 0.159 & 5.786 & 5.839 & 5.960 \\
Open Ended Mutual Funds & 8.847 & 0.310 & 8.623 & 8.765 & 9.004 \\
\hline
\end{tabular}

\begin{tabular}{lccccc} 
Treasury Bond Portfolio Maturity $_{k t}$ & mean & stdev & p25 & p50 & p75 \\
\hline Annuities & 9.826 & 0.558 & 9.369 & 9.936 & 10.219 \\
Life \& Health Insurance & 9.434 & 0.398 & 9.183 & 9.354 & 9.695 \\
Property \& Casualty Insurance & 5.601 & 0.158 & 5.507 & 5.614 & 5.736 \\
Open Ended Mutual Funds & 9.459 & 0.434 & 9.169 & 9.362 & 9.660 \\
\hline
\end{tabular}

\begin{tabular}{lccccc} 
Share of IG Corporate and Treasury Bonds & mean & stdev & p25 & p50 & p75 \\
\hline Annuities & 0.554 & 0.054 & 0.505 & 0.551 & 0.605 \\
Life \& Health Insurance & 0.725 & 0.023 & 0.705 & 0.733 & 0.742 \\
Property \& Casualty Insurance & 0.790 & 0.017 & 0.781 & 0.789 & 0.803 \\
Open Ended Mutual Funds & 0.532 & 0.040 & 0.499 & 0.529 & 0.571 \\
\hline
\end{tabular}

Table G.1: Summary statistics by investor type. This table shows summary statistics for the main types of investors, namely annuities, life and health insurers, property and casualty insurers, and open ended mutual funds. The top table shows the number of funds in each fund class and the total holdings of corporate and government bonds as of 2009:Q1. The last four tables show summary statistics about the QE Exposure variable, the maturity of the corporate and treasury bond portfolio, the maturity of the treasury bond portfolio, and the share of IG corporate and treasury bonds. 